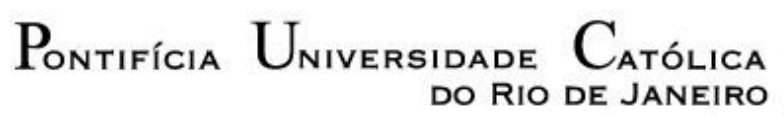

Gregory John Ryan

\title{
Custom Tailored Reality: A Realist Critique of Subjective Power in World Politics
}

\section{DISSERTAÇÃO DE MESTRADO}

\author{
INSTITUTO DE RELAÇÕES INTERNACIONAIS \\ Programa de Pós Graduação em Relações Internacionais
}




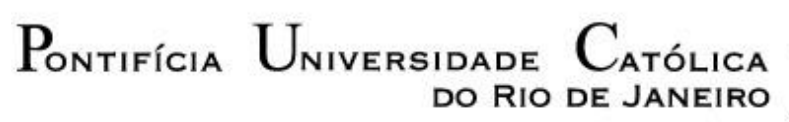

Gregory John Ryan

\section{Custom Tailored Reality: A Realist Critique of Subjective Power in World Politics}

\section{DISSERTAÇÃO DE MESTRADO}

Dissertation presented to the Programa de Pós Graduação em Relações Internacionais of the Instituto de Relações Internacionais, PUC-Rio as partial fulfillment of the requirements for the degree of Mestre em Relações Internacionais.

Advisor: Prof. Kai Michael Kenkel Co-advisor: Prof. James Casas Klausen 


$$
\text { Pontifícia Universidade Católica }
$$

Gregory John Ryan

\title{
Custom Tailored Reality: A Realist Critique of Subjective Power in World Politics
}

\begin{abstract}
Dissertation presented to the Programa de Pós Graduação em Relações Internacionais of the Instituto de Relações Internacionais, PUC-Rio as partial fulfillment of the requirements for the degree of Mestre em Relações Internacionais.
\end{abstract}

Profa. Andrea Ribeiro Hoffmann President Instituto de Relações Internacionais - PUC-Rio

Prof. Kai Michael Kenkel Advisor Instituto de Relações Internacionais - PUC-Rio

Prof. James Casas Klausen Instituto de Relações Internacionais - PUC-Rio

Prof. Eduardo Viola Universidade de Brasília - UnB

Profa. Monica Herz Coordinator of the Centro de Ciências Sociais da PUC-Rio

Rio de Janeiro, July $15^{\text {th }}, 2016$ 
All rights reserved

\section{Gregory John Ryan}

Ryan graduated in Information Technology from the Gewerblich-Industrielle Berufsschule Bern (GIBB) in 2002. In 2011 he concluded his bachelor degree in International Relations from Estácio de Sá University in Rio de Janeiro. In 2014 he attained a postgraduate degree in History of International Relations from the State University of Rio de Janeiro (UERJ).

Bibliographic data

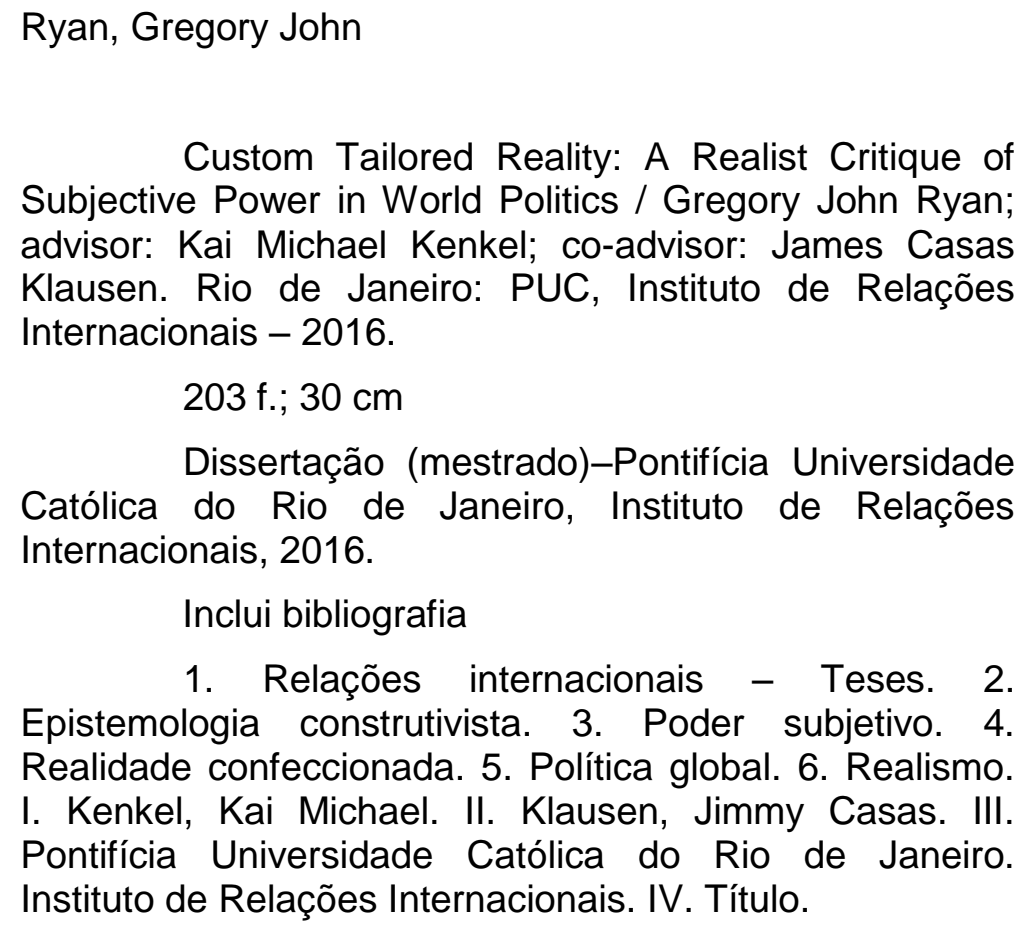


Für Bea, Tim und Dita, für euri immer währendi Ungerstützig, i aunä Momäntä. In Ahdänke ah John. 


\section{Acknowledgements}

I would like to thank Kai Michael Kenkel who had always guided and encouraged me in the course of the two years on my exciting sojourn as a student of international security, and on whom moreover I could always count for advice and support in all other matters. I would like to thank Jimmy Casas Klausen who, during the most critical phase of writing this text, always found the time for discussing and exploring Kant, the postmodernists, and all things on philosophy with me. I would like to thank Felix Dane, who for many years as the inspiring head of the KAS Brazil office enabled this extraordinary dual experience as a master student and professional in the vanguard of Euro-Brazilian political relations. I would like to thank the team and all the other professors at the Institute of International Relations at PUC, especially João Nogueira, for introducing me to critical theory and the postmodern approaches to IR. I would like to thank my dear colleagues at KAS and my many professional interlocutors and partners at the Brazilian legislative, the defence ministry, Itamaraty, the armed forces, the delegation of the European Union to Brazil, the European diplomatic community as well as the organized thinking communities on both sides of the Atlantic for their patience, trust and confidence in me as a builder of bridges and as a scriptwriter for joint Euro-Brazilian performances, and thus allowing me an environment in which I could reflect on theory and practice. You know who you are. I would like to thank my family, spread throughout the world, too numerous to mention all by name here, for supporting me in all my decisions and choices. I would like to thank my host family here in Brazil, especially Mery and Waltraud, for providing me with a delightful, inspiring and happy home. I would like to thank my many dear friends Kathrin, Eduardo, Robert, João, Gareth, Alexandro, Erik, João, Kristina, Leticia, Albert, Antonio, Philippe, Samira, Renato, Hugo, Sebastian, Stefan, Janosch, Leonardo, Cineme, Marcelo, Tarmo, Anna Paula, Antonio, and all you others, you know who you are, for lending me their ears and providing advice. Last, if this text had a tune it would be Bolero by Ravel. Much of it was written to the sounds of this beautiful masterpiece. 


\section{Abstract}

Ryan, Gregory John; Kenkel, Kai Michael (advisor); Casas Klausen, James (coadvisor). Custom tailored reality: A Realist Critique of Subjective Power in World Politics. Rio de Janeiro, 2016. 203p. MSc Dissertation - Instituto de Relações Internacionais, Pontifícia Universidade Católica do Rio de Janeiro.

The Prussian philosopher Immanuel Kant, after inquiring whether the human mind can grasp reality as it is in itself, came to the conclusion that reality and the appearance of reality are not the same. In fact, he concluded that the object must conform to the subject. Thinkers associated with postmodernism, by accepting these conclusions, came to argue that the appearance of reality is produced by subjects themselves and depends on relations of power and beliefs. This dissertation, through a close rereading of so-called classical realists with a postmodern perspective, proposes that in world politics, actors employ subjective power, which is understood as the power to interfere with ideas, with the goal of custom tailoring reality as is appears to targeted subjects. By drawing on postmodern thinkers, theoretical approaches are explored which serve in conceptualising how this process may be thought of. By drawing on the methodology of Pierre Bourdieu, the insights at which this dissertation arrives are applied to two historical cases, the French Revolution and the Soviet Invasion of Afghanistan.

\section{Keywords}

Constructivist Epistemology; Custom Tailored Reality; Subjective Power; World Politics; Realism 


\section{Resumo}

Ryan, Gregory John; Kenkel, Kai Michael (orientador); Casas Klausen, James (co-orientador). Realidade Confeccionada: Uma Critica Realista de Poder Subjetivo na Politica Mundial. Rio de Janeiro, 2016. 203p. Dissertação de Mestrado - Instituto de Relações Internacionais, Pontifícia Universidade Católica do Rio de Janeiro.

O filósofo prussiano Immanuel Kant, depois de questionar se a mente humana pode perceber a realidade como ela de fato é, chegou à conclusão de que a realidade e a aparência da realidade não são a mesma coisa; e que, na verdade, o objeto deve se conformar ao sujeito. Pensadores associados ao pós-modernismo, ao aceitarem estas conclusões, passaram a argumentar que a aparência da realidade é produzida pelos próprios sujeitos e depende de relações de poder e crenças. Esta dissertação, através de uma minuciosa releitura dos então chamados realistas clássicos - embora uma perspectiva pós-moderna - propõe que, na política internacional, os atores empregam o poder subjetivo, que é entendido como um poder que interfere com as ideias e com os objetivos de uma "realidade confeccionada" do jeito que ela se revela para os sujeitos-alvos. Inspirando-se nos pensadores pós-modernos, abordagens teóricas são aqui exploradas no intuito de conceituar a forma como esse processo pode ser pensado. Inspirando-se no método de Pierre Bourdieu, as conclusões obtidas nesta dissertação são aplicadas a dois casos históricos: a Revolução Francesa e a invasão soviética ao Afeganistão.

\section{Palavras-chave}

Epistemologia Construtivista; Poder Subjetivo; Realidade Confeccionada; Política Global; Realismo 


\section{Contents}

Preface

1. Introduction

2. Kant as the father of postmodernism

2.1 The Enlightenment and the relationship between reason and reality

2.2 Kant's inquiry into the relationship between reason and reality

2.3 Rationalist and empiricist arguments

2.4 The Kantian problematique

2.5 The universalist approach towards the production of reality

3. The postmodernist turn

62

3.1 Perspective as a condition for knowledge 63

3.2 Postmodernism, power and truth 66

$\begin{array}{ll}\text { 3.3 Postmodernists on power and reality } & 73\end{array}$

4. Realism $\quad 77$

4.1 Realism as a theory of international relations 78

4.2 Defining realisms core concepts and assumptions 81

4.3 A traditional reading of Thomas Hobbes 's realism 83

4.4 Neorealism and its critics $\quad 85$

4.5 Classical realism, postmodernism and epistemological compatibility 88

4.6 Realism as a form of critique of power in world politics 89

4.7 A critical rereading of the key concepts of anarchy and human nature 92

4.8 Anarchy reconsidered: the impact of competing beliefs 93

4.9 The mobilising power of fear $\quad 97$

4.10 Human nature reconsidered 100

5. The epistemological Leviathan and the imperative of common beliefs 105

5.1 Governmentality and the enforcement of a common beliefs 108

5.2 Global governmentality 114

$\begin{array}{ll}5.3 \text { Intentionality } & 119\end{array}$ 
6. The mobilising power of images and language 122

6.1 Language and images 127

7. The method of Pierre Bourdieu 132

8. Historical case one: The French Revolution and the rise of Napoleon 140

9. Historical case two: The Soviet Invasion of Afghanistan 163

10. Conclusions 186

$\begin{array}{ll}\text { Bibliography } & 193\end{array}$ 
If the mind is to emerge unscathed from this relentless struggle with the unforeseen, two qualities are indispensable: first, an intellect that, even in the darkest hour, retains some glimmerings of the inner light which leads to truth; and second, the courage to follow this faint light wherever it may lead.

Carl von Clausewitz, On War

Does one have to understand a work in precisely the way in which the age that produced it understood it? But one takes more pleasure in a work, is more astonished by it, and learns more from it, if one does not understand it that way.

Friedrich Nietzsche, Daybreak

On résiste à l'invasion des armées; on ne résiste pas à l'invasion des idées. (One withstands the invasion of armies; one does not withstand the invasion of ideas.)

Victor Hugo, Histore d'un Crime 


\section{Preface}

In the course of writing my dissertation, I came to draw on many different perspectives and philosophical considerations. The result is a large text, intensive in terms of theories and ideas. In order to make the text more accessible, I have decided to write this preface where I provide some further context and guidance to the reader on where I come from and where I intend to go to.

What is the role of ideas in world politics? How do ideas condition the social universe? How do ideas contribute to the construction of appearance of reality? How does one ideational perspective come to dominate other ideational perspectives? How do culture and diplomacy complement and/or contrast with material capabilities in world politics? How can ideas take hold among populations of subjects? How can power be employed to change ideas? What is the relationship between power and ideas?

Questions such as these which stand at the outset of this present work revolve around the problem of the role and nature of subjective power, as I came to know it as. I came to pose these and similar questions ever more systematically in the course of the last seven years, continuously standing with one leg in the world of politics and one leg in the world of academia. Soon after arriving in Rio de Janeiro in 2007, I signed up for a course on International Relations (IR) at a local university, which was fairly humble in terms of prestige and reputation. The curriculum of the course was very much dominated by North American approaches to the social sciences. Traditional European writings, dear to the Brazilian academia, such as those of Marx, Weber and Machiavelli, served as an intertextual backdrop to the course. In contrast, positivist modes of knowledge production, especially neorealism and interpretations of geopolitics with a universalist claim to materialist driven determinism, were thought of and marketed by the teaching body as the precise tools allowing professionals in the field of international relations to meaningfully understand the art of world politics. 
These positivist approaches to the social sciences to which I was first introduced claimed to be able to say universal and necessary truths about world politics by looking at material factors alone. By applying methods inspired by the natural sciences, these theories claimed to be able to extract universally true facts from the social universe, and then - through processing in theoretical models - be able to predict what was going on and what would happen next in world politics. In the discipline of International Relations, as it was taught to me, neorealism was said to be the main theory, offering supposedly the truth about world politics.

Already early in my time as a student, in 2009, I started to combine a life of studies with a life of practice. I was accepted as trainee at the Swedish consular mission to Rio de Janeiro. Although most matters focussed on affairs of private individuals, such as visa and passport questions, from time to time I was allowed a first-hand glimpse into the world of international politics. As I saw diplomats conversing, in formal and informal settings, I constantly reflected on the theoretical models which I was taught at the IR course I was studying, and how they could provide answers for what I saw happening in front of my eyes. Yet in such an environment, materialistic centric theories like neorealism and geopolitics could seldom offer any answers. As a low ranking consular clerk, I asked myself: "Why is it important for Sweden to make sure that student exchange programmes take place?", "Why is the honorary consul general supposed to be a person of a certain prestige and elegance - an insider of the social elite?", or "Why does Sweden care about the plight of minorities in other countries?". I pondered over many other issues, such as prison conditions, welfare policies and other questions linked to human rights and culture.

I thus found that Waltz's neorealism, and determinist geopolitical models inspired by Mackinder and Spykman are interesting when looking at the grand picture of world affairs, for example when following the narrative about great power politics as crafted by cable news TV channels ${ }^{1}$. Yet, in relation to my particular perspective, I

\footnotetext{
${ }^{1}$ This, in a way, is how my path as an observer of world politics started: When I was still a boy, I would spend a lot of time watching CNN. My Irish father was often on work related affairs in the Middle East, Africa and in what was then known as the Eastern Bloc. He was thus always interested in what was happening in the world, and I would join him in front of the TV. Great power politics became like a sports spectacle to me. The attacks against the United States of America on the eleventh
} 
found that the consulate could offer few answers for the conduct of world politics, as seen from the close up view allowed to me. A look towards the classics of political theory now and then seemed to offer some explanations. For instance, suppose we accept claims of the universal validity of Enlightenment derived approaches to human rights, as inspired by writers such as Spinoza, Locke and Rousseau (Russell, 2008). We then find that it makes sense that Sweden is interested in humans all over the world being treated in the same way - THE good, just and true way.

As Sweden considers itself to be in the vanguard of the struggle for the establishment of universal human rights, the country sees itself compelled by duty and obligation to help others by showing the light; encourage and aid stragglers onto the secure path towards progress (Wallerstein, 2006: 19-22). Or if we accept Marx's sociological considerations (always widely present in Brazilian academia), which claim that elite perspectives generally condition the perspectives held by the lower stratas of society (Jones, 2006: 54), and thus define what is true and what is not, then we may understand why a consul must be someone standing on equal footing with the elites. Otherwise, the consul's voice would not be heard. As for realism - I always found it interesting when reading the classical texts of Machiavelli (1999) and Hobbes (1904), how much they seemed to concern themselves with machinations, manipulations, appearances, shows, spectacles and other considerations which have little to do with rational actors calculating material factors. Yet, following the callings of the time in which I found myself, I thought that the classical realists had been superseded by neorealism, and that neorealism had thus come to be the standard interpretation of realism (Mearsheimer, 2014; Waltz, 1979). Or rather, I thought that the subjective power considerations which I found in the writings of the classical realists were interesting, but of little importance in light of contemporary positivist approaches to the study of international relations.

In 2011, I joined the team of the Konrad Adenauer Foundation (KAS) in Brazil. During the course of the following years, the questions underpinning this work came

of September 2001 had a strong effect on me, in that I became what the Americans call a "news junkie". I couldn't stop reading about world politics; watching the performance of great power politics as it unfolded live on TV and in the internet. 
ever more forcefully to the forefront. Reflecting on neorealism as the dominant theory of IR, claiming that world politics is almost exclusively conditioned by the distribution of material capabilities in a fixed space governed by anarchy, I asked myself, if the positivists' theories and premises are true, why do organisations such as KAS invest time and energy in arranging meetings, seminars, conferences and other types of exchanges which seek to bring together different perspectives on politics?

A post-graduation course on the history of international relations at the State University of Rio de Janeiro (UERJ) and a course on Brazilian perspectives on world politics offered by the Brazilian military further awakened in my consciousness that ideas play a role in world politics. Departing from neorealism, both courses focused on the classics of political thought, history and particular Brazilian perspectives on world politics. I learned about how Brazil saw itself at times as a firm member of the Western family of states (for instance during the "Republica Velha", or during the Second World War, when Brazil fought on the side of the Allies), and at times as a more autonomous actor (for instance when Brazil adopted the policies of "Equidistancia Pragmatica" or the "Politica Externa Independente"), reinventing itself as a member of the Global South, aspiring to lead the world's poor in the pursuit of common interests. Contrasting neorealism, which claims that world politics is about like-units (states) engaging each other in a space of anarchy, ordered by material power considerations, I came to understand that culture and identity matter in influencing and conditioning the articulation of foreign policy strategies: A Brazil which believes itself to be part of the West conducts itself differently than a Brazil which sees itself as an autonomous actor in world politics.

A further key insight, important to this project, I was given by one professor from UERJ, who made me aware that part of the power of realism as an approach to political theory lies in the fact that a great many policy makers trust in the value of realist insights. They in turn follow on realism prescriptions, and thus reproduce the very world they think the power sensitive theory of realism describes: they do what they think must be done by a rational actor. Realism thus prescribes and describes at the same time. Seen from that perspective, it could be questioned whether realism describes the world as it is, or whether it serves as a blueprint, drawn upon by policy 
makers which then make the world as realism sees it. However, as for theoretical models, I was offered little which could help me to better understand non-material power in world politics.

In 2014, I was accepted as a Masters student at the International Relations programme of the Pontifical Catholic University (PUC) of Rio de Janeiro. Right at the outset of my time at PUC, I was introduced to critical theory and postmodern approaches to theory. Suddenly, I was presented with theoretical approaches which allow for a sophisticated understanding of the role of ideas in world politics. As I always did before, I would leave the classroom, enter the world of practice, and then reflect on what I saw in the latter by drawing on what was said in the former. Conversely, many of the papers and projects I would write in the course of my time at PUC were centred on topics inspired by what I saw in the world of practice as part of KAS. I was always interested in how power and ideas come together. Contrasting with material power, which is at the core of neorealism, I came to understand subjective power as the power to interfere with ideas.

In the search for answers pertaining to the problem of subjective power, this Masters dissertation is thus largely rested on theories and thinking tools which are situated in what might be called the intertextual realm of postmodernism. The postmodernist intertext is an extremely complex and multi-faceted universe, and not easy to grasp by the uninitiated, especially since what postmodernism tells us about the world seemingly goes against our natural instincts (Tyson, 1999:239). In the course of two intensive years at PUC, I often came to compare the endeavour of mastering postmodernism to learning a new language - mastery can come only through time and practice. Reading an introductory book is not enough - one must constantly reflect and reconsider, and then reread what one has already read. What makes matters more complicated, in my experience, is that there are few who dedicate themselves to postmodernism, and consequently, there are only few with 
whom to converse about it. The process of learning postmodernism can be compared to the learning of a language outside the country in which that language is spoken ${ }^{2}$.

It is easy to get lost in the universe of postmodernism. This has to do with the claim of postmodernism that there is no universal perspective, no universal truth, but only individual perspectives and interpretations of truth. As different thinkers identified as canonical thinkers of postmodernism came to argue from different perspectives, the threads which might be weaved by considering the whole of the postmodernists intertextual universe might be limitless. Indeed, there is no one postmodernism, but many postmodernisms (Rosenau, 1999; Hart, 2004; Hicks, 2004; Sim, 1998). This should always be kept in mind, even when the term is used in the singular. Thus, when thinking about this project, and when thinking about the ideas to draw upon, I was advised to always keep in mind Occam's razor: Always keep it as simple as possible. Whether I have succeeded in such is for others to judge.

From a general viewpoint, I understand postmodernism as a form of scepticism. By looking at problems through postmodern perspectives, it is possible to see something, about something - yet not the universal and absolute truth (Hart, 2004:31). Each perspective might allow some limited insight about a given problem, yet never the whole picture. Indeed, at times there might be tension among postmodern perspectives, or even outright contradiction. There are, however, also a few assumptions which postmodernists share in common. The most important common outlook is that postmodernists accept the Kantian constructivist epistemology as their point of departure (Hicks, 2004:28). Thus as I draw on many writers, I am aware that there are fundamental tensions among some/many of these ideas - indeed, there may be some who will say that to combine the ideas in the way I did is impossible.

Yet with that in mind, I might remind myself that I do not aim at assembling or constructing a new theory - or say anything about universality and necessity in

\footnotetext{
${ }^{2}$ This, as a small anecdote: during two years, I studied Arabic at the Federal University of Rio de Janeiro. Every Saturday I would get up early and then spend the whole morning with others eager to learn the language. Ardently we studied the alphabet, the grammar and a basic vocabulary. However, two years on, we still were not able to converse. Portuguese, on the other hand, I learned very swiftly after arriving in Brazil. Daily exposure to the language made possible what a number of years at a weekly course could never have achieved.
} 
relation to world politics. I merely intend to employ different perspectives in the search for answers to problems which positivist social science approaches to international relations are unable to provide. Thus, when looking at the role of subjective power in the construction of the reality of world politics - for that is my topic - I endeavour to employ different kinds of postmodernist inspired perspectives.

I may console myself by remembering a central premise of postmodernism there is no absolute truth, but only interpretations. Jacques Derrida, for instance, finds any one-sided approach to interpretation ridiculous (Royle, 2003:9), and Roland Barthes once postulated that the author is dead, by which he meant that no one individual can claim to decide what a text must mean and what not - not even the author herself (Rosenau, 1999:25). As the (temporal or spatial or ideational) context in which the text is read changes, the meaning of the text may also change. Thus this text of mine is but an interpretation rested on reflections which I was able to gather in my work life, and my reading of the contemporary and canonical works of critical theorists, mainly postmodernists. By drawing on the method of Bourdieu, I apply the theoretical musings to two cases: First, the case of the struggle of the so called grand narratives of the divine rights of kings and reason during the Enlightenment, the French Revolution and the rise of Napoleon. And second, the case of the creation of the Mujahedeen in the wake of the Soviet invasion of Afghanistan. 


\section{Introduction}

The late 1970s. The last remaining US military advisors have returned from Vietnam. Yet the memory of the war is still fresh, tormenting America. Nam, hat unpopular war on the other side of the globe; that war which came close to tearing the American Republic apart. The women and men of the US military find themselves demoralised; the popular legitimacy of the almighty American military force has reached a low point. On the global stage, America has lost prestige and influence. At home, the American public is engaged in long debates, soul-searching and often violent clashes between once united groups (Scott, 2007:3). The insiders of the national security apparatus, however, claim to know exactly what went wrong. Their fingers are pointed firmly at the Moscow. Without Soviet support for the Viet Cong, so reasoned the security establishment, America would have prevailed against the former French colony in South East Asia. Among those who studied these matters closely was Zbigniew Brzezinski, the national security advisor to the incoming Carter administration (Scott, 2007:31).

Brzezinski, an ardent student of history and the social sciences ${ }^{3}$, understood that the Soviets supported the North Vietnamese not only with weapons and logistics, but also with doctrines, organisational capabilities and a strategic concepts: in other words, ideational contributions (Leffler and Westad, 2010b:38). The Soviets not only assisted with material capabilities, but they also inserted themselves in the intertextual foundation which oriented the Viet Cong in what they supposedly are,

\footnotetext{
${ }^{3}$ Brzezinski concerned himself since his time as a student with questions on nationalism and ideologies. He focussed especially on the nationalities of the Soviet Union, and how particular national identities and the supposedly universalist Marxist perspectives relate to each other. He authored several books which touch on subjective power, including Political Control in the Soviet Army, Ideology and Power in the Soviet Politics (Brzezinski, 1970). In International Politics in the Technetronic Era Brzezinski foresaw the global awakening of mankind through the spread of communications technology, and pondered about the consequences such would have for great power politics (Brzezinski, 1971).
} 
and what they supposedly want, and how they supposedly can get what they want. The beliefs of those conducting the war, and of others relevant to the outcome of the struggle, were theatres of interest to the Soviets. Naturally close to the NorthVietnamese leadership by adherence to a shared ideological worldview, the Soviets took on a position in the vanguard of the Vietnamese war effort, albeit in secrecy, and hidden from the public eye.

Brzezinski, a relentless enemy of the Soviet Union, was bent on destroying the communist empire. What he understood very keenly, was that the Soviet Union depended on the force of the common belief in communism. By encouraging alternative beliefs, for instance beliefs conditioned by a privileged understanding of identity, or religion, the communist common belief would crumble, and the Soviet Union with it. As early as 1966, Brzezinski co-authored a confidential report with the political scientist William Griffith, criticising Radio Free Europe and Radio Liberty for being too passive (Scott, 2007:50). They argued that the broadcast programmes should adopt a more militant line when directed at the none-Russian minorities in the Soviet Union, encouraging the rise of alternative perspectives to communism. For Central Asia, Brzezinski subsequently came to articulate a plan which would be tailored around existing grievances and dissatisfaction of Muslim communities inside the inside the Soviet Union, and in its vicinity.

After the election of Jimmy Carter to the US Presidency, the national security establishment continued to look for a chance for revenge for Vietnam (Scott, 2007:43). The chance seemed to have arrived when the Soviets found themselves ever deeper committed to an armed struggle in Afghanistan (Tanner, 2009). Brzezinski, was at the forefront of devising a plan by which the Soviets could be handed a Vietnam of their own. To arrange for the shipment of weapons to the antiSoviet party was only one part of the plan. To attain desired outcomes, Brzezinski understood, the minds of people had to be targeted; or rather, their beliefs, and that as such, the war of ideas would be a major component in any operation. Ideas had to be encouraged which would turn groups of subjects against the Soviet Union (Scott, 2007:51). Indeed, actions deployed on the battlefield of the mind would create the conditions of possibility which would in turn lead to a Soviet defeat. Several 
ideational factors of relevance were identified and then targeted. The key battle ground centred around the concept of the New Soviet Man in Central Asia. The New Soviet Man was the ideal subject in the eyes of the Soviet leadership since Lenin (Khodorovich, 1998). The New Soviet Man was supposedly an identity which could overcome nationalism and other types of sectarianism and thus could bring all individuals within the Soviet Union together as one group - a united group, supposedly, of equals.

The ideal of the New Soviet Man was propagated throughout the Soviet Union. It was essentially inspired by the Marxian ideal of a universal identity propagated during the First International in 1864 in which Marx himself participated. No matter what ethnic, religious or other sectarian character a given people had before the arrival of the Soviet Union, the New Soviet Man was a new identity which would bring all together. Indeed, Stalin and Beria were Georgians. Trotsky was Jewish. Khrushchev was Ukrainian. Yet all were also Soviets (Montefiore, 2014), and the Soviet identity was supposed to dominate national identities, religions and /or cultural considerations. Once introduced and established, by relentlessly conditioning all subjects within the reach of the Soviet State, competition among members of different sectarian outlooks would cease to take place, and all would unite in working towards the greater good of all. Or at least, that was the hope.

For the US revenge-plan regarding Afghanistan, where the ideal of the New Soviet Man was in an incipient stage ${ }^{4}$, it meant that alternative identities - hostile to Marxism - had to be encouraged. As the American security policy makers around Brzezinski put their minds to the problem, they found a situation in which there were several ideational alternatives already present in the region, and thus there were several perspectives which could have been supported and encouraged - built up as

\footnotetext{
${ }^{4}$ I use the term "ideal", since up until the communist coup of 1978, the Afghan political leadership did not use the term explicitly. Yet Daoud Khan, the foremost Afghan modernizer, who played a central role in Afghanistan since the late 50s until the communist coup, aimed at modernising his country by encouraging Western and Soviet aid programmes alike in his country. He hoped that through these programmes, modern modes of thought would take hold in Afghanistan. Thus for him Soviet and Western influences both served in the same end, in as that he saw both as helpful in overcoming traditionalism (Coll, 2004:26). After the coup, the communist leadership implemented radical programmes which were designed to recondition Afghan subjects in accordance to the ideal of the New Soviet Man in the shortest possible time.
} 
the champions of anti-Soviet activities. These perspectives included, among others, various forms of tribalism, Sufi flavoured nationalism ${ }^{5}$ and Islamist fundamentalism (Scott, 2007:91). In the end, the decision was taken to tailor a strategy which would see the rise of radical Islam as the anti-Soviet Champion.

The US thus got involved after President Carter followed the advice of Brzezinski, thereby encouraging fundamentalist Islamism. There were several reasons which favoured this strategy. First, it would allow the US to cooperate with other interested parties, chief among them the governments of Pakistan and Saudi Arabia, both US allies. Both were already actively spreading radical Islam in the region. And second, by encouraging radical Islamism, it was conceivable to create the conditions which would then threaten the Soviet Union in other areas, such as inside its member republics in the Caucasus and Central Asia (Scott, 2007:50). Little did the tailors of this strategy concern themselves what such a policy might mean for the future decades ahead ${ }^{6}$.

As the US thus enabled the logistics, while functioning ultimately as the central coordinator, radical fundamentalist Salafist preachers were brought into the region, Korans were translated and distributed, and subjects willing to fight in the name of Islamic fundamentalism were trained and armed (Rashid, 1995:45). The Mujahedeen were born in the process. At the same time, the US drummed up support for the cause of the Mujahedeen at home and throughout the world. Hollywood did its part, and so Rambo in his third appearance was deployed to Afghanistan where he assisted in part the Mujahedeen, who were portrayed as the victims of aggression, fighting a just cause (Kaplan, 2006). The result was that the idea of the New Soviet Man in Central Asia was severely challenged, and insurgents rallying under the banner of radical

\footnotetext{
${ }^{5}$ In Afghanistan, similarly to the Central Asian Soviet Republics such as Turkmenistan and Uzbekistan, Sufism had long been the dominant approach to Islam (Rashid, 1995:44). Sufism is defined as the inner mystical dimension of Islam. Sufism is often seen to represent an example of a moderate interpretation of Islam, quite the opposite of Salafism, the epitome of a radical interpretation of Islam.

${ }^{6}$ The handlers of the programme were aware that the strategy of encouraging radical Islam was not without dangers. However, as Brzezinski affirmed in an interview with the French when asked about the blowback of the operation years later: "Brzezinski: What is more important in world history? The Taliban or the collapse of the Soviet empire? Some agitated Muslims or the liberation of Central Europe and the end of the Cold War?" (Scott, 2007:51).
} 
Islam were suddenly seen as freedom fighters", fighting the "evil empire". About a decade on and many tens of thousands of lost lives, the dream of a modern society in Afghanistan was shattered, modernism discredited in general, and the Soviet Union had no other option than to retreat broken and in humiliation. The Soviet attempt of tailoring an Afghan social universe inspired by the Soviet New Man succumbed to the uncompromising dedication of the zealots bent on imposing radical Islam - created and supported in turn by the anti-Soviet coalition.

\section{Deploying subjective power}

The United States was able to produce the Soviet Afghanistan disaster not by merely delivering weapons to existing rebels opposed to the Soviets. Rather, measures were deployed - through actors directly or indirectly commanded - by which changes in the structuring of the appearance of world politics, as cognised by key target groups of subjects, preceded - and enabled - changes in the ordering of material factors in world politics, as well as changes in the conditions of possibility for their employment (Scott, 2007:50,80; Brzezinski, 1997:2). In the quest for dealing the Soviet Union a Vietnam of its own, the Afghan social universe was thus custom tailored by the US and its allies in such a fashion so as that the country was turned into a highly hostile environment towards all things associated with communism and modernism in general.

Up until well into the 1970 s, the Soviet Union was in a relatively comfortable position in Central Asia. The communist empire entertained relatively friendly relations to the self-proclaimed Afghan president, Mohammed Daoud Khan (Coll, 2004:24). Afghanistan received aid in several areas from the Soviet Union, including

7 Radical interpretations of Islam have served now and again as an ideational perspective allowing for the galvanising of opposition forces against undesired governing forces in particular areas. In 1899, Britain invaded South Sudan to subdue a self-proclaimed Mahdi who was calling for Holy War against British controlled Egypt and the British themselves (Churchill, 2013). During the First World War, the Turkish Sultan - as an ally of the Germans - called for Holy War against the Entente powers (Keegan, 2000). In the wake of the Second World War, Egyptian Muslim Brotherhood member Sayyid Qutb went to the US and returned disillusioned by consumerism. The book "Milestone" he wrote subsequently is widely recognised today as the ideational fundament on which Al Qaeda and other radical Islamist groups stand, and upon which they draw when justifying attacks against civilians (The Guardian and Irwin, 2001). 
infrastructure projects, training of professionals, military capabilities and other development projects. Daoud, intent on modernizing his country, entertained an open door policy. In 1978, after the Afghanistan communists took power, they were bent on accelerating the process of modernization which Daoud had started.

Mercilessly the new Afghan communist leadership instituted programmes which were meant to recondition the subjects of Afghanistan in accordance to the premises of Marxism. Yet as people were forced to be free ${ }^{8}$, quite the opposite of what was intended started to happen: People flocked in ever greater numbers to the banners of traditionalism. Traditionalism in Afghanistan was largely defined by varying interpretations of Islam and tribalism. The dominant interpretation of Islam was inspired by Sufism and other moderate interpretations if Islam, whereas radical Islam was traditionally largely unknown in the region.

Thus, when the United States decided to take the opportunity for revenge for Vietnam, there were a number of groups which could have been chosen as proxies, and thus a number of ideational alternatives which could have been encouraged in opposition to the Soviet perspective. However, in the end, the United States decided that radical Islam should be strengthened as the most potentially powerful anti-Soviet force (Scott, 2007:81). In order to be able to do so, a concert of actors ultimately enabled by the United States targeted theatres located in instances imperative in the production of reality; sites that are susceptible to manipulations, and that play an important role in structuring the beliefs cherished by subjects. Once beliefs cherished by subjects are successfully altered, the appearance of the social universe in which world politics eventually takes place to them changed correspondingly.

Korans were translated into local languages and distributed in the region, fundamentalist preachers from Saudi Arabia were brought to Central Asia with the help of the Pakistani intelligence service ISI, and already converted Mujahedeen fighters were trained and supported by the anti-Soviet coalition (Scott, 2007: 90). Once the minds of a critical number of subjects were reconditioned in accordance

\footnotetext{
${ }^{8}$ Rousseau, in the Social Contract (1968:64), argued that in certain situations, subjects need to be forced to be free. Robespierre interpreted this argument in order to justify his regime of terror. Later, other regimes would do the same.
} 
with the perspective of radical Islam, they would start to see the Soviet Union and her representatives as infidels which must be fought. As the body of subjects in Afghanistan whose beliefs were structured by radical interpretations of Islam reached critical mass, the Mujahedeen resistance was born (Scott, 2007: 90). Or rather, as the beliefs cherished by these Mujahedeen were reconditioned, they were turned into committed anti-Soviet fighters. Moreover, training programmes organised by the secret services of the United States, Pakistan and Saudi Arabia made sure that the constructed resistance force could stand up militarily to the Soviet Army on the battlefield (Coll, 2004: 19).

The results were far-reaching. Relations between actors and material factors were recast and realigned, lines defining friendly and inimical relationships were redrawn, and thus the balance of power changed correspondingly. The conditions of possibility involving the employment of material factors were changed in scope and in mode (Scott, 2007; Coll, 2004).

In order to understand intervention in subjective domains which aim to influence the appearance of reality to subjects, this dissertation intends to draw on the Kantian constructivist epistemology, postmodern perspectives on the relation between power and beliefs, as well as insights derived from writers generally seen as canonical classical realists. A rereading of classical realism through the lens of postmodernism is then performed, whereby the focus is set on the implications of anarchy and human nature for world politics. By employing what may be called a kind of a postmodern realism as a form of critique, it is then endeavoured to understand subjective power in world politics.

\section{Providing a roadmap through the text}

Before engaging the large body of theory which will follow in the subsequent chapters, it is beneficial to go back to the outset of the dissertation. What is the problem which inspired this dissertation? The problem which stands at the outset of this dissertation is centred on the relationship between ideational factors and power. It is probably safe to say that most social scientists and policy experts agree that ideas 
and beliefs are important. Yet in the study and conduct of world politics, ideas and beliefs are often overlooked as a factor concerning power. This problem is reflected the dominance of positivist approaches to the social sciences (neorealism in IR) which privilege objective factors to the detriment of subjective factors. Postmodern thinkers, however, by pointing to the conclusions at which the Prussian philosopher Immanuel Kant arrived at when engaging the philosophical questions of his time, argue that the subjective considerations condition objective considerations, and that positivist approaches such as neorealism are flawed since they assume the contrary to be valid. Ideational factors, following thus the postmodern argument, are central to power political considerations. In order to understand the postmodern perspective, and the implications for our problem, we start by going back to Immanuel Kant and the questions with which he concerned himself in his time.

Kant was interested in understanding whether the human mind can grasp reality as it is in itself, or if not, what that means for the premise of reason (Hicks, 2004:32). What brought Kant to ponder this question was the claim that reason, arguably the main concept of the Enlightenment, would be able to directly order reality, and thus once unleashed - would be able to create a world of perfect beauty, freedom and equality (Bristow, 2010).

To get directly to the outcome: Immanuel Kant concluded from his critical inquiries into the relationship between reason and reality that human subjects, or rather, their minds, cannot aspire to understand the world objectively as it is (Hicks, 2004:33). Kant, who set himself to this problem after reading David Hume, a leading sceptic of his time, eventually concluded that the object must conform to the subject, and not the other way around, as empirical realists claimed the nature of this relationship to be (Hicks, 2004:35). This insight has an important implication for the premise of reason, and for the ability of theoretical models to treat what is thought to be reality.

Reason was the central concept of the Enlightenment. Its champions (i.e. those inspired by the advances of the natural sciences) hoped that reason, unhindered by traditional authority, could come to understand all aspects of human life as it is in 
itself, and then could reorder the social universe in such a way so as to create a world of universal justice and freedom (Sim, 1998). Kant understood reason to be inferential operations involved in logical justifications and explanations; other thinkers of his time may have held other respective interpretations (Buroker, 2006:16). Through reason, its champions argued, the emancipation of mankind could become a reality (Luchte, 2007:22). However, Kant observed that the human mind cannot connect directly to the objective world, a conclusion to which he came after considering the arguments of empiricists and rationalists of his time. Reason, he concluded, is therefore limited to processing its own subjective products (Buroker, 2006:32). Or rather, reason is thus limited to processing what it itself has created through ultimately unverifiable assumptions about what the world is in itself. This means that there is no universal truth about the social world which human subjects can know and understand. But rather, what subjects believe to be reality is actually an appearance of reality, conditioned by forms and concepts as present a priori in the minds of observing subjects. These forms and concepts are derived in the Kantian understanding from knowledge which is eventually created by subjects themselves (Buroker, 2006:35). Kant nonetheless hoped that by recognising these limits, mankind could work together in the process of knowledge production, and thus by applying a common (universal) perspective, and through the help of experiments, could eventually arrive at universal and necessary truth about the social universe (Gardner, 1999:9-16).

Later generations of thinkers, adherents of the continental school of philosophy, came to disagree with what might be called Kant's universalist idealism ${ }^{9}$. Nietzsche argued that there is no universal perspective through which mankind as a whole could gaze on the social world (Rosenau, 1999:13). Indeed, instead there are a myriad of perspectives emanating from individual subjects and groups of subjects (Grant 2001:29). What is thus true for one perspective may not be true for another perspective (Spinks, 2003:37-38). Moreover, for postmodernists, knowledge as understood by Kant - as it is available a priori to subjects - is supplemented by other

\footnotetext{
${ }^{9}$ Because it implies a universal perspective. For Kant, beliefs do not matter. Kant only considers knowledge, which he understands as a unified body, true for all, and independent of perspective.
} 
systems of beliefs, such as religion and ideology; or is simply misinterpretation, superstition and false ideology. Thus, rather than subjects depending on knowledge from which they derive forms and concepts in the endeavour of producing reality; subjects in fact depend on beliefs: what subjects believe to be true is not necessarily informed by universal knowledge (Williams, 2005; Rosenau, 1999). Rather, it rests on assemblages of belief systems, including knowledge, religion, ideology and other systems of beliefs.

Subjects are conditioned in accordance with beliefs that are dominant in the spatiotemporal configuration in which they grow up and exist. Accepting this argument, postmodernists have suggested that appearance of reality and reality are not the same thing (and have even questioned whether there is such a thing as reality), and that appearance is ultimately the product of relations of power and beliefs ${ }^{10}$. Beliefs are available to subjects a priori. Beliefs are claims about what reality is supposed to be a priori to engagement with it. As beliefs change, the appearance of reality changes accordingly. What is reasonable in light of a certain understanding about what reality is supposed to be may becomes unreasonable when seen through another perspective. (Edelman, 2001; Williams, 2005).

In the academic study of world politics, the dominant neorealist approach claims that it can explain the workings of its object of study just by looking at the distribution of material factors among actors, which it understands primarily (but not exclusively) as states (Mearsheimer, 2014). This claim rests on other claims to universalism, to necessity, and to positivism, as well as a certain way delimiting how reason functions (Walker, 2010). Neorealism thus came about in line with the neokantian school of thought (which represents the post-Kantian strain of philosophy which works with the assumption that there are universal and necessary perspectives which can be found and uncovered) (Sim, 1998; Schrift, 2010c:47-85). Neorealism assumes that there is a universal perspective on world politics which can be identified and then mapped out. In doing so, neorealism ignores the implications of the postmodern turn in the social sciences. In reflection of such, contemporary critical IR

\footnotetext{
${ }^{10}$ Again, by using the term "belief", the author hopes to go beyond the more limited meaning of knowledge, which may be understood as a body of soundly verified claims about reality.)
} 
scholars such as RBJ Walker (2010:38) argue that the positivist social sciences could be compared to classical physics (Newtonian physics), whereas postmodernist approaches are comparable to quantum physics.

Postmodern approaches argue that the neorealist approach is ultimately flawed, for it assumes that there is a universal perspective on world politics (Linklater, 1990). Moreover, neorealism claims that it is able to cognise this universal position and that it thus can produce knowledge which is universally true and necessary. Postmodernists, however, argue that the Kantian insight in the wake of Nietzsche means that there is no universally true perspective on world politics, and that what is said to be a universal perspective is actually a particular perspective which has been successful in prevailing over others in determining the outcome of power struggles (Spinks, 2003). Yet, postmodernists understand that neorealism is powerful, since policy makers - believing its claim to truth - employ its mode of thought when cognising world politics: they thus reproduce what they think is supposed to be, thereby making true what otherwise would not necessarily be true (Malpas, 2003).

Consequently, a preliminary question must be: What does reason ${ }^{11}$ say about world politics, if it is assumed that appearance and reality are not the same, and that appearance can ultimately be manipulated, shaped, conditioned, moulded and formed through subjective power?

A look towards realism as the main school of international relations holds some answers (Donnelly, 2005). Authors who are often seen as the canonical thinkers of so-called classical realism understood the role and importance of subjective considerations of power - almost naturally - since they did not limit themselves to rigid epistemological and ontological commitments, which is the case for neorealism and other positivist approaches to the social sciences (Williams, 2005).

Classical realists agree that reason plays a central role in guiding agents. Whereas neorealists limit themselves to looking at material considerations, which

\footnotetext{
${ }^{11}$ I ask what reasons would say, since neorealism and other forms of realism claim that actors are guided by reason, and that thus what they do in world politics is informed by reason. If we assume that only the distribution of material factors matter, reason may say something, yet when we understand that ideas also play a role in relation to power, reason may come to other conclusions.
} 
they claim all relevant actors can eventually come to agree upon as universally true and objective facts; classical realists understand that ideas - and the ability to condition them - play a central role in world politics driven by power: Actors are not necessarily powerful in an objective sense, but they are powerful because they are able to define what is true and what is not; what is good and what is not, what is supposed to be, and what is not supposed to be ${ }^{12}$. Classical realists thus contemplate the role and centrality of beliefs in power considerations, which makes them epistemologically compatible with postmodern thought (Rösch, 2014).

In the course of the Fourth Debate - a debate initiated by social scientists in the 1980s which centred among questions of ontology, epistemology and eventually methodology - positivist theories, including neorealism, came under serious strains, as postmodernists and critical theorists came to raise questions which the former were unable to answer (Benneyworth, 2011).

In more recent years, classical realists have been reread through a critical perspective, sensitive to considerations of subjective power (Williams, 2005; Walker, 2010). Here too, it is worth remembering that there is no single valid interpretation for classical realism. Different writers thought of as classical realists have taken up different perspectives: Machiavelli (1999) pondered over power from the perspective of the prince; Hobbes (1904) was worried about the survival of subjects in anarchy; Clausewitz (1984) considered power from the perspective of the war fighting party; Carr thought about power in the context of the global institutional framework (Molloy, 2006); and Morgenthau (1973) looked at power through the perspective of the global statesman.

The questions and considerations that these classical realists contemplated were thus often quite different. What the founders of realism as a social science did (confusingly nowadays also called classical realists, i.e. Carr, Morgenthau, Niebuhr

\footnotetext{
${ }^{12}$ When framing such a complex process in such simple claims, I am aware that I risk omitting the special role of knowledge: As argued, knowledge comes about by the employment of sound methods and critical inquiry, and is different from other systems of beliefs in that it allows subjects to control the material world and aspects of the social world. An actor in control of advanced scientific knowledge, such as the United States, is able to control material factors in a more sophisticated, efficient and powerful way.
} 
and others) in the wake of the Second World War, was to extract from classical realists (writers from among the European political tradition who came before the First World War) insights about power, said to be timeless and unchanging (Knutsen, 1998). In the most basic of understanding, classical realism claims that actors, ultimately conditioned by human nature, sharing a common existence in anarchy, must always strive to secure the levels of power necessary to guarantee their own survival (Donnelly, 2005). The actions designed to attain such are guided by reason, for reason demands survival. Moreover, classical realists understand that power has both a subjective and an objective dimension (Rösch, 2014). Material power allows actors to coerce other actors into doing what they otherwise would not necessarily want to do. Hard power military capabilities may be thought of as straightforward expressions of material power. Subjective power denotes the ability to condition belief, or ideas in general, and thus to make subjects do what they come to think they must do - for subjects do what they do because of the beliefs they cherish. In other words - since all actors, including states, are made up by (groups of) subjects - the capability to influence what subjects believe reality to be is expressed through subjective power (Edelman, 2001; Williams, 2005).

Indeed, Clausewitz, Hobbes and Machiavelli all deploy arguments in their writings which underscore the importance of subjective power considerations. Machiavelli reminded the Prince that appearance and reality are not the same thing, and that appearance and power are related: to look strong in the eyes of the observer leads the observer to assume that the strength he sees is real (Machiavelli, 1999). Hobbes (1904) worried about competing beliefs which lead to conflict: "The actions of men proceed from their opinions", he wrote, and thus he argued that a common belief is of paramount importance in enabling peace and tranquillity, since otherwise when everyone judges for himself what is a threat and what is not - conflict is inevitable. Clausewitz, observing matters from a different perspective, argued that the outcome of any battle is also the result of what actors make out of it: a defeat can be the end, or the moment when new forces can be mobilised (Strachan, 2007). In other words, Clausewitz disagreed that material factors determine the outcome of a war; he understood that ideational factors play a central role in all aspects of conflict. When 
pondering over how it was possible that an invading French force could beat and rout the defending Prussian army twice its size (at the Battle of Jena and Auerstedt), he concluded that the weapons and tactics employed by the two forces were much the same, but that the ideational factors of morale and inspirational leadership were clearly in favour of the invading French. The French, mobilised, energised and invigorated by a sense of exceptional historical role, believing themselves to be the liberators of mankind, simply overawed the peasant conscripts filling the ranks of the European royal armies (Strachan, 2007).

In sum, classical realists recognise the importance of beliefs in power politics. The conditions of possibility, as given in any social world, ultimately rest on beliefs. Subjective power in turn is understood as interfering with beliefs. Of course, classical realists are not interested in power considerations limited to the realm of the subjective only; but rather, they are interested in how subjective and material power condition each other; how subjective power can be used to achieve ends which are eventually worldly affairs. Neorealism, on the other hand, does not consider the importance of ideas. Neorealism assumes that all actors are rational, and that they all may access the same body of knowledge, which is said to be universal (Benneyworth, 2011). For neorealists, ultimately, only material factors matter.

A postmodernist rereading of classical realism can aspire to uncover the workings of subjective power in world politics (Pashakhanlou, 2009). Classical realists have long understood that - through subjective power - actors can condition and recondition other actors, and thus change the way those targeted subjects understand the social universe, i.e. what they believe to be true and what they believe not to be true.

This brings us to the question underlying this dissertation: Considering that ideas and beliefs, and thus subjective power, are factors which actors in world politics must consider how do actors engage this problem? What does a postmodern rereading of realism as the dominant school of international relations say about subjective power in world politics? 
Let us thus observe the hypothesis underlying this dissertation: If the postmodernist inspired assumption is true - which states that reality and appearance of reality are not the same, and that, moreover, appearance of reality is conditioned by relations of power and beliefs - then it is possible to change the appearance of reality by changing the beliefs cherished by subjects. This is done through what the author calls subjective power. Subjective power is aimed at beliefs. Beliefs inform the ideas that are available to cognising ${ }^{13}$ subjects a priori, and from which concepts and forms are derived necessary in lending sense and meaning to the phenomenological world. Cognising subjects produce reality by integrating representations of reality as provided by them through sense organs into concepts which are derived from ideas which in turn are informed by assemblages of systems of beliefs such as knowledge, religion and ideology. By changing what a subject, or a group of subjects, believe to be true (i.e. what assemblage of systems of beliefs they cherish), it is possible to change reality as it appears to these subjects. Actors thus may employ subjective power in order to change what other actors (which are always ultimately made up by at least one subject) believe reality to be - and thus what adequate, desirable and legitimate actions are, and what not.

Thus if this assumption is true, then states (or other actors) must concern themselves with subjective power. Inside states, the struggle involving subjective power is restrained through the presence of an actor with a legitimate claim to sovereignty. The state, looking inwards, aspires to order the commonly accepted rules and norms of conduct, and to condition the regime of truth - i.e. the commonly accepted beliefs which are said to be truths. Looking outwards, however, in the space of the international, no single actor is vested with the same legitimate claim to order all others. Consequently, the employment of subjective power outside of states, by

\footnotetext{
${ }^{13}$ Throughout this text, the verb "to cognise" is understood as the act of taking in information flows as provided by the sensory organs derived from the phenomenological world (Rockmore, 2006:10; Kant, 1998: 8-12). To cognise is thus a kind of a passive act. The production of reality, on the other hand, is what happens when internal representations of the world (internal in the sense that they exist in the head, representing what is supposedly "out there") are integrated into concepts and forms available $a$ priori to subjects (Hicks, 2004:46; Kant, 1998: 8-12). Reality, or rather the appearance thereof, is thus produced by the subject. In that sense, cognition and production are always fused - for the reality one cognises, is the reality one has produced a priori.
} 
powerful states, may lead to conflict, when actors strive to export their perspectives, which they may claim to be universally true (Wallerstein, 2006). Indeed, through subjective power, actors all over the world may be engaged and reconditioned in terms of what they believe to be true about reality (Williams, 2005). Moreover, due to the nature of anarchy in the space of the international, different beliefs are bound to clash, as there is no single actor that can legitimately order all beliefs. Understanding the importance of subjective power, states thus may well employ subversion, engage in manipulation, and generally strive for attaining the preeminent position for defining what is (un)truth and what is (im)possible in world politics. For, if states and other actors with a claim to autonomy remain passive and unresisting, they will find their subjects - nominally under the state's reach - conditioned by ideational factors originating in the designs of others.

This brings us to the main body of theory which is built upon as a theoretical basis in writing this dissertation, namely postmodernism ${ }^{14}$ and classical realism. Indeed, most time and energy was invested in thinking and writing about theory. Postmodernism is understood to be a form of scepticism: a set of thinking tools which can be employed in criticising given objects of critique from different perspectives (Rosenau, 1992). Insights can be uncovered which are not provided by positivist approaches to theory. Postmodernism thereby is not understood as a coherent body of theory, but rather as a myriad of perspectives, some of which may disharmonise with one another, or even contradict each other. Postmodernism is interesting for the purpose of this dissertation, since it allows one to consider how beliefs (and/or ideas in general) relate to considerations of power. Once a number of postmodern perspectives of interest to this dissertation are laid out, a critical rereading of realism is performed. In doing so, realism is first thoroughly engaged. Classical realism and neorealism are looked at and their differences are considered. The close rereading of classical realism which is performed highlights aspects of subjective power. Through a postmodern realist approach to critique, the implications for subjective power in

\footnotetext{
${ }^{14}$ As I had made clear in the opening, having worked many years in the field of the world of politics (in an impossibly minor role), I was always very keen in understanding how ideas and beliefs work in world politics. Postmodern approaches seemed to me most powerful in providing answers.
} 
world politics are then explored. This in turn leads to the engagement of further postmodern perspectives.

Let us now have a look at the method to be employed in this dissertation: this text intends to draw on the method of Pierre Bourdieu in applying its theoretical assumptions on two historical cases (the case of the Soviet invasion of Afghanistan, and the case of the French Revolution and rise of Napoleon). Bourdieu has, during his intellectually productive lifetime, contributed a set of what he calls thinking tools, which allow one to understand struggles of power between actors which involve material and subjective considerations. The late French philosopher and sociologist argues that in the production of the social universe, subjective factors dominate objective factors. However, in opposition to hard core postmodernists, which claim that anything is possible, Bourdieu argues that objective factors (material factors) constrain the conditions of possibility according to which subjective factors can come to articulate themselves. Yet nonetheless, Bourdieu is in line with postmodern thought in as that he argues that what a subject thinks reality to be is guided by the beliefs that are cherished a priori to engagement with the phenomenal world. Through the Bourdieuian method it is possible to understand how subjective and material power relate to each other, and thus how the employment of subjective power can lead to changes in the distribution of power among actors, as well as how subjective power can come to condition the possibility for employment of material factors in world politics (Bourdieu and Wacquant, 1992).

Bourdieu argues that reality (or rather, the appearance of it) comes about through a process which is conditioned by a dialectic relationship between what he calls the "objectivity of the first order" and the "objectivity of the second order" (Bourdieu and Wacquant, 1992:11). The "first order reality" is given by the material structure, while the "second order reality" comes about as the product of the cognising subject, who integrates representations of "the world out there" into concepts conditioned by particular beliefs (knowledge, culture, ideologies, misrepresentations and other systems of beliefs). Both structures are linked, yet not in a fixed, constant manner. Hence, any given constellation of material factors leads to more than one single possible corresponding ordering of the second order reality, and 
vice versa (Bourdieu and Wacquant, 1992:7-10). By changing the beliefs that subjects cherish a priori, a change in the material order can thus follow suit.

The method of Bourdieu allows for a set of conceptual approaches for thinking about relations between subjective and objective factors. Key conceptual thinking tools are the "field", the "habitus" and the "doxa" (Bourdieu and Wacquant, 1992:16). According to the social theory of Bourdieu, actors struggle in what he calls fields, for desired stakes. A field comes about where two or more actors compete for a stake. The struggle in the field among actors is conditioned by the distribution of material factors and by the set of rules explicitly and implicitly accepted by all, which Bourdieu calls doxa (Bourdieu and Wacquant, 1992:98). The doxa denotes the commonly accepted rules and norms which govern interaction between actors in a given field. The doxa may also be an object of strategy: by changing the doxa, the rules can be changed. Actors may entertain particular perspectives which correspond with the positions they take up in the field. The particular perspective is captured by the habitus, another key concept of Bourdieu (Bourdieu and Wacquant, 1992:20). The habitus corresponds with the second order reality; essentially the particular perspective held by the subject in question. The habitus thus is conditioned by the beliefs a given subject cherishes. Reality, as it is experienced by subjects, comes about as the outcome of a dialectic relationship between the first order reality, the field, and the second order reality, the habitus (Bourdieu and Wacquant, 1992; Bigo, 2011).

Thus, by reading the workings of world politics through the lens of Bourdieu's social theory, while focussing on the postmodern insight that appearance is manmade, in combination with the normative approach of the classical realists who dedicate themselves to the study of power, we come to the understanding that appearance is conditioned by relations between power and beliefs, and thus power working through the subjective can affect the ordering of material factors in world politics. Recognising this relationship between subjective power and its impact on material factors, actors are driven towards struggle and competition. Indeed, struggle in subjective theatres - as this dissertation argues - is an important feature of world politics, for it could be argued that she who controls the production of reality, may 
aspire to control the world. Why draw the sword, if the word can achieve the same result?

Let us now have a brief look at the chapters which are to follow: Chapter two: This chapter is about Kant's constructivist epistemology. As the basis for the core assumptions of postmodernism, it deserves a deeper look. We start at the very beginning, by looking at the Enlightenment. We then trace the historical circumstances of Kant's life. What was the nature of the time in which Kant was born? What were the questions the philosophers of his time pondered over? What were the most important debates? What was Kant's argument? Although the concept of reason is not the main object of study of this dissertation, we touch on it frequently since it was the main concern of Kant, and moreover, the concept of reason retains a central role in the social sciences. We look at the debate between the empiricists and the rationalists in detail since the conclusions and difficulties they encountered still remain relevant for our own times. We then explore the Kantian constructivist epistemology; how it allows one to understand the postmodern claim, according to which reality and the appearance of reality are not the same. This chapter is intense in terms of theory, and does not touch directly on world politics.

Chapter three: We explore the post-Kantian world of philosophy. Neokantianism accepts the premises of Kant, yet by claiming there is a universal perspective, the school continues to follow the hopes of the empiricists and rationalists of the Enlightenment: through constant research and study, universal and necessary truth about the social world can be uncovered (Schrift, 2010c:47-85). Neorealism is the outcome of neokantianism. Postmodernists, following the perspectivist move of Nietzsche, reject the neokantianist outlook. Perspectives condition the appearance of reality: what is thus true for one subject does not necessarily hold true for another subject. Moreover, appearance of reality (and thus perspective), is conditioned by relations of power and beliefs, which are understood to be assemblages of knowledge, religion, ideology and other particular perspectives on the social world (Aylesworth, 2015). Power conditions beliefs: what is taught in schools, what is accepted as legitimate textual contribution in the public space, what is encouraged, and what is repressed (Dean, 2010). Conversely, beliefs condition 
power: what is the legitimate application of material and subjective power and what are the conditions of possibly defining material capabilities ${ }^{15}$ available to a given actor (Sim, 1998; Malpas, 2003). As is the case with chapter two, chapter three is mostly concerned with theory, establishing the understanding how reality and the appearance of reality are not the same, as well as how power comes to structure the appearance of reality.

Chapter four: This chapter is dedicated to realism. To be clear from the outset, we do not intend to look at contemporary postmodern approaches to realism, but rather, we intend to look at the tradition of realism, and what a rereading of the classics through the postmodern lens can say about our problem at hand. We start by looking at realism as a school of international relations. We trace the history of development of the school. We attempt to define realism and identify its core assumptions and concepts, especially regarding anarchy and human nature. We then look at the traditional interpretation of realism as based on the writing of Thomas Hobbes. After that, we have a closer look at Neorealism. We understand neorealism as a child of the structuralist revolution in the social sciences which occurred in the aftermath of the Second World War in the United States, when the centre of academic thought was moved from Europe to America. We understand that the rise of neorealism has led to the dismissal from mind of key insights about subjective power, once cherished by classical realists (Williams, 2005). After considering how postmodernism and classical realism correspond epistemologically, we then take a critical look at the basic assumptions of (classical) realism and re-evaluate them by highlighting subjective considerations of power. We follow in the trail of Michael Williams (2005), who argues that Hobbes was concerned about conflict born from divergent or competing beliefs. The implications of this rereading of Hobbes means that the Leviathan, as idealised by (neo)realists, must not consider material factors only, but must also establish common beliefs. Otherwise - when there is disagreement

\footnotetext{
${ }^{15}$ It is worth nothing here that the conditions of possibly defining the material capabilities is mainly related to knowledge as understood in the original Kantian sense, i.e. knowledge which can say things which are universally true and necessary (i.e. the natural sciences).
} 
on what is the good and what is the bad, what is a threat and what is not - ceaseless conflict will result.

We then reconsider human nature in the light of postmodern ideas about relations between beliefs and power. Hobbes (1904) said that, through language, the status quo beliefs can always be challenged, and lasting and immediate reactions can be provoked. This corresponds with Kant's view that we can always think about the future, as long as we stay within the conditions of possibility given by knowledge, intuition and reason (Rastovic, 2011). Paradoxically, this ability can lead to conflict: as we always tend to think in worst case scenarios, which frighten us, we come to act in irrational ways and thereby create the situation we actually want to pre-empt by our actions in the first place (Williams, 2005). Indeed, through the use of language and images, the status quo beliefs cherished by subjects can be contested and changed at any time (i.e. even of the most thoroughly conditioned subjects), and the subjects targeted can thus be mobilised for a desired end. (Edelman, 2001)

Chapter five: This chapter looks at the implication the problem of anarchy has on human existence, where actors do what they do based on particular beliefs, absent common beliefs which allows them to agree on what is the good and what is the bad. We consider several approaches towards conceptualising common belief systems how do they work, how to they come about, what is the role of power in them? It is argued that, since a state of anarchy is a state which makes coexistence for subjects impossible, there must be actors that function as epistemological leviathans (possessing overawing power which enforces common beliefs). The world is thus divided into a number of spaces in which actors, vested with sovereignty and legitimacy, strive to condition subjects within their reach in accordance to desired beliefs.

We then explore how states aspire to shape subjects in accordance with certain beliefs. In doing so, they provide the core ingredients which subjects must draw upon when engaging in the production of the appearance of reality. By drawing on the theoretical concept of governmentality, it is argued that actors consciously and intentionally condition subjects within their reach. The approach of governmentality 
on which is drawn was articulated by Mitchell Dean (2010), who in turn derived it from Michel Foucault. The manner in which the concept is employed in this text leads to the suggestion that there is room for intentionality: it is argued that actors can aspire to control the process of governmentality. However, Foucault always made very clear in his writings that there is no room for intentionality. Hence, Bruno Latour's Actor-Network-Theory (ANT) (Latour, 2005) is briefly considered, in arguing for a case by which it is possible to envision how actors can come to aspire to intentionality when structuring the beliefs through which subjects are conditioned. (As will be argued, the emphasis should be on aspire - for even the most sophisticated strategies may come to produce outcomes that are quite contrary to intentions.)

Chapter six: By looking at the problem of competition and struggle through the human nature side, we explore how language and images can inspire thoughts in subjects which may come to challenge what a given subject believes a priori about the world (Williams, 2005; Edelman, 2001). By challenging the status quo beliefs cherished by a given subject, appearance of reality to subjects can come to change. Language and images are thus powerful instruments for mobilisation of subjects.

Chapter seven: The method of Bourdieu is explored. How do subjective and material powers interact? How can the interplay of material powers and subjective powers in world politics be conceptualised and understood?

Chapters eight and nine: Theoretical insights are applied through the method of Bourdieu to a first case which focuses on the French Revolution and the rise of Napoleon. The case centres on the struggle between the so-called grand narratives of the divine right of kings and reason. In feudalism, the divine right of kings ordered the beliefs cherished by subjects. The Enlightenment championed a position of sovereignty for the concept of reason in ordering human existence. A clash between the two ensued. After the camp of Enlightenment prevailed in France, its representatives - through the revolutionary state of France - instituted a governmentality machine which reconditioned the French subjects in accordance with the premises of the Enlightenment. The forces which were consequently unleashed 
allowed Napoleon to conquer the whole of Europe. In a second case, the role of subjective power in the Soviet invasion of Afghanistan is inspected, wherein the United States used subjective power to construct a resistance force opposing the Soviet army. The hitherto rather docile Central Asian populations were radicalised through the distribution of translated Korans and the encouragement of Wahhabi preachers from Saudi Arabia. The resistance forces were then trained in the use of weapons and tactics. At home and around the world, their cause was promoted as just and in favour of freedom. As the beliefs cherished by a critical number of subjects changed, the balance of forces in the region was changed. The Soviets were in the end beaten, and had to leave communist Afghanistan to its own devices. 


\section{Kant as the father of postmodernism}

We find, too, that those who are engaged in metaphysical pursuits are far from being able to agree among themselves, but that, on the contrary, this science appears to furnish an arena specially adapted for the display of skill or the exercise of strength in mock-contests - a field in which no combatant ever yet succeeded in gaining an inch of ground, in which, at least, no victory was ever yet crowned with permanent possession.

Kant 1998, B xv

Thinking back on Kant's text, I wonder whether we may not envisage modernity as an attitude rather than as a period of history. And by "attitude," I mean as a mode of relating to contemporary reality; a voluntary choice made by certain people; in the end, a way of thinking and feeling; a way too of acting and behaving that at one and the same time marks a relations of belonging and presents itself a task ... [R] ather than seeking to distinguish the "modern era" from the "premodern" or "postmodern," I think that it would be more useful to try to find out how the attitude of modernity, ever since its formation, has found itself struggling with attitudes of "countermodernity."

Foucault, “What Is Enlightenment?" quoted in Molly, 2006:35

As already argued, there is no single coherent approach to postmodernism; there are indeed many postmodernisms. Different thinkers thought of as postmodernists have different ideas about different aspects of relevance to the social universe (Aylesworth, 2015; Rosenau, 1999; Hart, 2004). They do not agree on everything with one another. Indeed, many of their approaches lie in tension to one another, or even contradict each other. Yet what all postmodernists share is that they accept the conclusions at which the Prussian philosopher Immanuel Kant arrived in his critical inquiries into the ability of metaphysics to say anything about reality as perceived by human subjects.

In order to understand the core assumptions ${ }^{16}$ of postmodernism, which came about as a reflection on the works of Kant, this chapter will explore the particularities of the times of the Prussian philosopher, the problems with which he concerned himself, his conclusions, and their implications for postmodernism. This is done

\footnotetext{
${ }^{16}$ From Kant, as we will see, postmodernism derives the following core assumptions: 1) reality and appearance of reality are not the same (indeed, objective reality - reality as it is in itself - can never be grasped by human subjects); 2) appearance of reality is expressed in terms of forms and concepts available a priori to the cognising subject; 3 ) forms and concepts are derived from systems of beliefs held a priori by subjects. However, in relation to this third point, Kant gives priority to an Enlightenment ideal of knowledge which claims that a universal perspective is possible. Postmodernists, however disagree with Kant on this relation. They agree with Nietzsche, who denies that such a thing is possible. Rather than think of knowledge as a universal body, postmodernists point to belief systems which can be understood as assemblages of knowledge, religion, identity, ideology and other ideational frameworks.
} 
comprehensively, since many of the questions and problems which marked the times of Kant and his contemporaries, are still present in our own times. During Kant's time, there were great hopes that the human mind would be able to understand the world as it is in itself. By studying the true, objective world, as it is in itself, humankind - by employing reason - would be able to uncover all secrets, and would in turn be able to aspire to total mastery of the social and material worlds. However, Kant, after studying Hume, came to the conclusion that it is impossible for humans to directly connect to the world as it is in itself. This insight motivated Kant to engage the problem of reality. Yet, even as Kant's conclusions stand true until today (Schrift, 2010a), generations of other thinkers continued to dream the dream of the Enlightenment: to uncover all secrets (for instance, neorealism is the child of such a continued hope). By reflecting on the times and debates of Kant, we can better understand what postmodernism is about, as well as acquire further perspectives from which to ponder over the current state of debate which engulfs our own times.

\subsection{The Enlightenment and the relationship between reason and reality}

Kant was born into the ongoing debate of the Enlightenment. The Enlightenment was a philosophical movement which dominated thinking circles in 18th century Europe (McPhee, 2012:10-13). Its leading protagonists, such as Voltaire, Diderot, Locke, Rousseau, Montesquieu, Hume, Adam Smith, Newton, Bacon and others, challenged the rationale underpinning the feudal order which dominated their social existence, as it had done for the forgone millennium in Europe.

The feudal order was based on the divine rights of kings (McPhee, 2012:85). It foresaw a divinely sanctioned cast system, where the few - the clergy and the nobility - were vested with privileges allowing them to legitimately dominate the rest of society - the common people. Inspired by earlier generations of thinkers, including Bacon, Descartes, Locke and Spinoza, 18th-century Enlightenment thinkers set out to challenge the grand narrative of feudalism. As a substitution, they offered the promise of a world in which the values of ideals of liberty, equality, progress, reason, 
tolerance and fraternity predominated (Dupre, 2004:1-12). The world they dreamt about would see an end of abuses at the hands of the few in positions of privilege. Everyone was supposed to be equally free - the Enlightenment promised nothing less than the emancipation of human kind (Easthope 1998:18). In the post-feudal world order which they envisioned, reason was to play an outstanding role, as reason was foreseen to serve as the fundament which would make everything possible. It is thus no coincidence that the Enlightenment is also often called the Age of Reason (Porter, 2001:7).

Three Englishmen feature prominently in the rise and success of reason as the central theme of the Enlightenment: Francis Bacon, who worked on empiricism and the scientific method; Isaac Newton, who dedicated himself to physics; and John Locke, who focused on reason, empiricism and liberal politics (Hicks, 2004:24). The confidence in the power and central importance of reason underlies all of their works. As their ideas became ever more prominent and influential in England and beyond, reason established itself ever more centrally in the philosophical landscape of the West (Hicks, 2004:24).

By employing reason, the champions of the Enlightenment argued, mankind could uncover all the laws which govern the reality in which humans are placed (Kors, 2003:3462-3466). In the realm of natural sciences, and linked fields, such as engineering, manufacturing and construction, the new mode of thought had already yielded stunning successes. The age of industrialism and scientific revolution surged ahead even as the old social order was still standing (Porter, 2001:29).

As is true with all concepts of the social sciences, the concise nature and scope of reason was understood differently by respective Enlightenment thinkers (Hicks, 2004:30). However, a certain broad consensus existed that reason is a cognitive faculty of the subject, that reason functions in accordance with universal and necessary principles, and that reason is competent in knowing the reality as it really is. The last assumption, that reason has direct access to reality, is of key importance to the construction of the perfect world, as promised by the champions of reason. It implies that through the study of reality as it appears to humans, objective reality as it 
is in itself can be uncovered, and then be processed by reason. In doing so, reason can come to formulate universal and necessary concepts about every aspect of human existence: in such a world, there are no mysteries, no secrets and no surprises (Kors, 2003: 3459-3466). Humans can aspire for complete mastery over social life and come to enjoy a world of liberty and equality, as was the premise of the Enlightenment.

Reason, with the help of ever more refined scientific instruments, would be able to understand reality, and to work all aspects of material and social existence into science (Kors, 2003: 3781-3786). In relation to the natural sciences, reason was able to quickly and steadily show its power, allowing for ever greater advances in the human endeavour of controlling nature. The general principles extracted through the scientific method allowed reason to conceptualise these, with the assistance of mathematics, into general laws of nature (Rastovic, 2011:22). Manufacturing, engineering, chemistry, war making capabilities and all other areas related to the material aspect of human existence flourished - and still do.

In the social realm, progress was harder to come by. Indeed, the inability of metaphysics, as the discipline which dedicated itself to the study of human reality, to come to any useful conclusions led Kant to set himself to critically examining the relation between the human mind, reason and reality as it is in itself (Gardner, 1999:18-20). The conclusions at which Kant arrived would revolutionise the tradition of western philosophy, and would eventually come to serve as the foundation for postmodernism and other critical approaches to philosophy. In the next parts we will thus explore how Kant engaged the problem, and what insights he took from this. Understanding these ideas in detail is important when aspiring to understand the premises of postmodernism, and how in conceptual terms it can be argued that reality and appearance of reality are not the same.

\subsection{Kant's inquiry into the relationship between reason and reality}

During Kant's life, the philosophical debate on reason was marked by the question of whether reason as a cognitive function of the human mind is capable of drawing on objective material facts as present in the world-and processing this input 
in guiding human action (Buroker, 2006:7). Those championing reason argued that the scientific method would allow for doing so. Yet Kant, after reading Hume - which he credited for awakening him from his "dogmatic slumber" - came to doubt whether that would be possible and thus embarked on a critical inquiry into metaphysics, reason, and reason's relation to reality (Luchte, 2007:32).

To look specifically at the relation between reason and reality was due to the grand postulations the metaphysics of his time made in regard to reason, some of which - in light of his reading of Hume - he would start to doubt. For Kant, metaphysics represents "the inventory of all we possess through pure reason, ordered systematically" (Kant, 1998:A xx). Yet as it seemed to Kant, in the light of Hume, the authority of reason was in question, and the premise of metaphysics was flawed. Kant's primary aim was thus to determine the limits and scope of pure reason; to know what reason alone can determine without sensory perception, without contact with "the real world out there". The Critique of Pure Reason (Kant, 1998), which Kant wrote during an 11-year retreat from almost all social life (Luchte, 2007:11), and which he explained as an experiment in metaphysics, came to seriously undermine some of the main hopes held by the Enlightenment, while preparing the ground for the rise of critical and postmodern approaches to philosophy.

As he set to his grand task, Kant was - and ever remained - an admirer of reason, arguing in the foreword of the first edition of Critique of Pure Reason that reason "is such a perfect unity" that it could indeed furnish all the solutions to the problems of metaphysics (Buroker, 2006:16). Kant argued that reason is governed by a single principle, and that it has a single function. That function is to provide forms for knowledge (Luchte, 2007:43). The solution to all problems of metaphysics thus would come through the proper institution of reason, followed by the acquirement of sound knowledge. Kant thus recognised that the state of metaphysics at the time of his entry into the debate was flawed, and thus could not deliver what it promised. Hence, the goal of Kant was to rework the framework on which metaphysics stood and insert reason in a proper way. 
Kant, it should be pointed out here, uses reason in his writings in three important senses. In the broadest sense, Kant employs reason in reference to all subjective processes involved in knowing. In a second way, Kant understands reason in reference to intellectual - as opposed to sensory - capacities. In a third, precise, form, Kant uses reason in order to refer to the inferential operations involved in logical justifications and explanations. This third sense of reason is distinguished from the interpretation of reason as the faculty of judging. Kant identifies the flaw of traditional metaphysics in relation to reason in the third, narrowest sense (Buroker, 2006:16).

Kant thus set out to critique the premises of reason, using reason itself (Gardner, 1999:73). Kant aimed to demonstrate, through his experiment, that a critique of reason by reason itself, unhindered by traditional authorities, can establish a secure and consistent basis for both Newtonian science and traditional morality and religion. The dual aim was important to Kant, as he believed that a free rational inquiry adequately supports all of these essential human interests and confirms them to be mutually consistent (Hart, 2004:31). Hence, Kant hoped that reason would be able to attain the sovereignty attributed to it by the Enlightenment - to flourish fully without having to submit to traditional authority, while not contradicting traditional approaches to morality and religion (Gardner, 1999:137). Yet in many ways unintended, his considerations on the relationship between reason and reality wrecked the hopes of the champions of reason, and instead came to constitute the fundament upon which the continental approach to philosophy - and eventually postmodernism was to be erected.

While there are many considerations of importance to come out from Kant's conclusions, for this dissertation, one point in particular is of importance: Brought to the point, Kant asked in his Critique of Pure Reason whether reason is capable of knowing objective reality, and he inferred this not to be the case (Hicks, 2004:28). The consequence of this conclusion is that it is the subject that structures the object, and not the other way around, as direct realists (empirical realists) claimed (and hoped). In order to understand how Kant came to this conclusion, and what the consequences are with regard to custom tailoring of reality, we have to take a closer 
look at the debate between the so-called empiricists and rationalists during Kant's time.

\subsection{Rationalist and empiricist arguments}

Already before Kant had set his mind to the problem of reason and reality, the two Enlightenment schools, rationalism and empiricism, had concerned themselves with just that question (Gardner, 1999:23). Both schools shared the desire to cement the premise of reason. Yet each school started from a different axiomatic position. The empiricists started by looking at the world "out there" (the observable world), and by using tools and instruments in mapping it; the rationalists started by problematising reason itself, and mapping out its capabilities with the aid of logic. The empiricists hoped to come to know the world by closely looking at it, while the rationalists hoped that the world must correspond to reason, and thus to know reason would lead to knowledge about the world. However, by the time Kant had taken up an interest in the matter, both schools were thoroughly engaged in seemingly insurmountable problems (Hicks, 2004:30). The problem, as both came to agree, was that reason cannot directly draw on the objective, material, world.

For reason to aspire to objectivity, it must be able to be in direct touch with the objective material reality, the noumenon, as Kant called it, by which he meant the world as it is in itself (Kant, 1998:338). In aspiring to do so, subjects employ their sensory perception organs. Direct realists (empirical realists) claimed that through sense perception, reinforced through technical instruments, it is possible to draw on reality as it objectively exists (Kors, 2003: 3459-3466). These impressions provided by scientific instruments, supposedly faithful instances of reality, could then be processed into concepts by reason, and subsequently could be turned into propositions and theories - thus was the argument of the champions of reason. The perfect world which the Enlightenment promised, a world marked by liberty and equality, was only a question of time, as scientists would eventually unlock even the last secret. Progress would forever mark human experience (Wallerstein, 1999:10). 
However, two arguments stood in the way of the realist argument (Hicks, 2004:30): The first argument states that sense-perception is a causal process. By understanding that it is a causal process, it can be inferred that reason comes to be aware only of an internal representation at the end of a causal process, and not of the object where the process began (Gardner, 1999:35). The senses thus are in between reason and reality.

The second argument takes into consideration that sensory perception varies through space and time, and from individual to individual. One person sees an object as red, another sees the same item as green. The horizon appears as a straight line, dividing earth and air - yet we know it must be slightly rounded, as the globe is a spheroid. An orange tastes sweet when eaten after a salty dish, but not sweet at all when eaten after something full of sugar. What is thus the real colour, the real shape, or the real taste of the examples mentioned? It seems that it is impossible to establish an agreement on the nature of things, as each individual subject comes to different conclusions (Luchte, 2007:48). These conclusions may even be approximate, yet never identical. Each individual thus relies on sense perceptions which are subjective effects and which may differ from perspective to perspective. Reason thus must rely on representations which are subjective effects, as it cannot draw directly on the objective reality as existing in the real world.

Both of these arguments have in common that they lead to the recognition that human sense perception is infused with particular identities, that sense organs work in specific ways, and that the internal representations of reality which individuals attain are a function of the employed sense organs' identity. The recognition that human sense organs have an identity means that they are an obstacle for direct contact between consciousness and reality (Rockmore, 2006:101). Taken together, the two arguments imply that sense impressions are not faithful impressions of reality, but rather internal representations of objects, moulded and shaped by the nature of human sensory organs, and thus tainted with subjective elements. The implication of this argument is that an obstacle is erected between the subject's mind and "reality out there". And thus if reason is only able to draw on an internal representation of reality and not reality itself, then reality becomes something that must be aspired to; deduced 
from the representations which the sensory organs produce from the input as received from the "real world out there". Reason, following this train of thought, is thus not able to draw on reality, but only on a representation of it. Or in reference to the special Kantian terminology, reason would not be able to draw on the noumenon, but only on representations of the phenomena. ${ }^{17}$

The empiricists hoped that it would be enough to be aware of the limitations, and thus urged caution when coming to conclusions (it could be argued that this argument still stands today). The rationalists discarded sense perception as a source of truth and argued that other sources must therefore be found which can lead to a path of knowledge (Hicks, 2004:31). In this manner, both looked at abstract concepts as a way out of the dilemma posed by the inability of direct contact between reason and objective reality (Rockmore, 2006:27).

The empiricists, building on an understanding that all human beliefs must be linked to the world by experience, argued that concepts must come about as inferences from experience (Rockmore, 2006:26). However, this proposition ran into the problem that concepts thus crafted are two stages removed from reality, and are therefore not contingent. Hence, concepts are human artifices, results of our choices. They cannot be true with certainty, and are eventually only true in the context of the humans who made them. Or in other words, concepts, as seen from the empiricists' perspective, cannot be universally true and necessary (Hicks, 2004:32).

Rationalists, arguing that necessary and universal truth cannot come as a result of human interaction with the world - yet insisting that there are universal and necessary truths out there - argued that concepts must have another way to be attained than through sense experience (Buroker, 2006:20). The problem for the relation between humans and the world, however, is that since concepts are not derived from the realm of sensory experience, they can also have no definitive value for the objective world.

\footnotetext{
${ }^{17}$ Although the phenomenal world can be accessed, it can never be grasped directly. But rather, subjects rely on representations of representations. Or in Kant's words: "Since no representation pertains to the objects immediately except intuition alone, a concept is thus never immediately related to an object, but it is always related to some other representation of it. Judgment is therefore the mediate cognition of an object, hence the representation of a representation of it" (Kant, 1998:B 93)
} 
Kant thus synthesised these two insights and concluded that if concepts can aspire to universality and truth, then they cannot have anything to do with sense experience; and conversely, that if concepts must be derived by experience from the real world, then we have to abandon the idea that they are universally true and necessary: if they can be uncovered only by empirical means, then they are always manmade and thus true only in the context in which they were produced. (Hicks, 2004:32). "What we here require is a criterion by which to distinguish with certainty between pure and empirical knowledge. Experience teaches us that a thing is so and so, but not that it cannot be otherwise" (Kant, 1998:B iii). Put in other words, universality and sense experience (necessity and experience) have nothing to do with each other.

Reason, as it was articulated by Enlightenment thinkers, is built on concepts. The double insight which Kant drew means that either the concepts upon which reason is built are merely provisional contingent groupings of sense experience, or, the concepts upon which reason relies have nothing to do with sense perception, and thus are disconnected with the reality out there.

These conclusions derived from the two schools were to constitute the fundament upon which Kant would rest his critique (Hicks, 2004; Rastovic, 2011; Buroker, 2006; Gardner, 1999; Luchte, 2007). For our purpose these conclusions are important to acknowledge: Firstly, by understanding that reason and reality are unable to connect directly, we understand how it is possible to think of the subject structuring the object, and not the other way around. The implication of this insight is that reality and the appearance of reality are not the same, as the appearance of reality is eventually produced by the cognising subject which employs forms and concepts $a$ priori available to itself when producing the appearance of reality. Secondly, although Kant and other critics remain correct in their conclusions until today, positivist approaches to the social sciences continue to argue that - through empirical means - they can come to create insights which are universal and necessary (Hicks, 2004:36). Neorealism is an example of such an approach to the social sciences which claims that it can look at material factors, measured by empirical means, and then make predictions about the course of world politics. However, when considering 
Kant's insights, we come to understand that such a thing is never really possible, and that the positivist social science approaches, even if very powerful indeed, are always prone to produce flawed knowledge, because they claim to see universality and necessity where there is actually none. Moreover, we can understand how actors can use what we call subjective power in interfering with the production of reality. Before we move on to consider the Kantian constructivist epistemology, let us look in more detail at his Critique of Pure Reason (Kant, 1998), and his conclusions for metaphysics, and eventually postmodernism.

\subsection{The Kantian problematique}

Up to now it has been assumed that all our cognition must conform to the objects; but all attempts to find out something about them a priori through concepts that would extend our cognition have, on this presupposition, come to nothing. Hence let us once try whether we do not get farther with the problems of metaphysics by assuming that the objects must conform to our cognition, which would agree better with the requested possibility of an a priori cognition of them, which is to establish something about objects before they are given to us.

Kant, 1998:B xvi

In the preface to the second edition of the Critique of Pure Reason, Kant opened by explaining his critical method as an experiment in metaphysics (Kant, 1998:B xvi). The aim was no less ambitious than to initiate an entire revolution in the philosophical thinking akin to the revolution in cosmology caused by the writings of Nicolaus Copernicus (Kant, 1998:B xvii). Copernicus had critically challenged the Ptolemaic geometric system, for its assumption that the whole celestial body revolves around the observer seemed inadequate in explaining the movement of stars. As an alternative to this geocentric approach, Copernicus suggested a heliocentric cosmological system: the apparent movement of heavenly bodies was a result of the observer being stationed on earth, which revolved around the sun. Through this change of perspective, Copernicus believed that cosmology would be more successful as an approach to science. Analogously to the Copernican revolution, Kant hoped through his critical work to be able to provide future generations of metaphysicians a secure path to science (Gardner, 1999:25).

Inspired by the feat of Copernicus, Kant starts his endeavour by looking at the foundations of science in order to find a secure footing for metaphysics. In the 
preface to the second edition of the Critique of Pure Reason, Kant explains the foundations of mathematics, physics and logic in order to discover a secure path on which metaphysics eventually can be placed. Two criteria for science are pointed out by Kant (1998:B vii). First, if - from a sound starting point - science makes persistent progress, then the secure path towards success for the science in question is given. Second, for constant progress to come about, the scientists working in the area in question must do so by accepting a common aim, while using the correct methods (Luchte, 2007:9).

For Kant, logic constitutes an example of the achievement of the sure path of science. The premises of logic were articulated by Aristotle and have remained unchanged since. Kant comments "That logic has advanced in this sure course, even from the earliest times, is apparent from the fact that, since Aristotle, it has been unable to advance a step and, thus, to all appearance has reached its completion." (Kant, 1998:B viii). Logic, since it was brought forth by Aristotle, until the days of Kant, had not taken a single step backwards or forwards. Every act of supplementing logic, for instance by interpolating it with psychological, metaphysical, or anthropological considerations, is "not improvement but a deformation of the sciences when their boundaries are allowed to run over into one another" (Kant, 1998:B viii).

As Kant a saw it, the boundaries of logic are precise, and logic allows for the formal conditions of valid thinking without any reference to the objects of cognition. As Kant argues, logic is enclosed within limits which allow for a perfectly clear definition; it is a science which has for its object nothing but the exposition and proof of the formal laws of all thought. Thus, for Kant, logic can provide the secure path of science, if reason remains within its fixed scope and reach, and thus does not deal with the external objects of cognition. In other words, this means that reason defines itself $a$ priori as a pure form of $\operatorname{cognition}^{18}$ without any reference to knowledge derived from other sources, such as experience. A priori cognition is given if it is

${ }^{18}$ Kant distinguishes two types of cognition: First, A posteriori, cognition which begins with experience (Kant, 1998:B i), and second, A priori, cognition independent of experience. 
structured by necessity and strict universality: "Necessity and strict universality are therefore secure indications of an a priori cognition, and also belong together inseparably" (Kant, 1998:B iv). A priori cognition is produced by the mind. For Kant, mathematics is a product of a priori cognition (Kant, 1998:B Xv). Since mathematics is a product of the human mind, Pythagorean numbers are really only human constructions, and not found in "the real world out there". Thus following Kant, mathematical calculations are always a priori since they are built on necessity and universality (Gardner, 1999:35).

Kant uses a simple calculation to underscore his point: $7+5=12$. The concept of the sum 12 comes about as the unification of two numbers, $7+5$, into a single number. To reach the concept of the sum 12, the subject which does the calculation must thus go beyond the concepts 7 and 5 by "seeking assistance in intuition" which is adequate in relation to these numbers.

Whereas logic is about the formal rules of all thinking without any reference to "the real world out there", mathematics and physics are employed by cognition with the aim of obtaining knowledge about objects outside the mind; to allow for determining objects a priori (Kant, 1998:B x). The success of mathematics in cognising objects thus depends on the ability to construct them according to a priori concepts (Kant, 1998:B xii). While mathematics and physics share a common aim, the difference between them is that mathematics constructs the objects inside the mind of the subject, while physics works with the objects as they are found in the phenomenal world (not the real, objective world, but the world as it appears). Mathematics and physics, however, had not always been with the human species, and thus each required a revolution before they were able to place themselves on the secure path of science (Rastovic, 2011:21).

These revolutions instituted a transition from gathering examples about mathematics and physics towards the understanding of the universal principles underlying the fields. The first steps of these revolutions, which allowed them to respectively attain the status of a science standing on secure footing, took place in a distant past, and so, similarly to the history of formation of language, have not been 
recorded. Yet looking at the revolutionary contributions made to mathematics by the Greek sophist Thales allows Kant to make his point. The revolution initiated by Thales was grounded in the recognition that the method of mathematics is not derived from the inspection of geometrical figures, or by way of studying the properties of geometrical figures, i.e. through empirical means; but rather, the revolution in mathematics came about by the understanding that geometrical figures, as with other mathematical outputs, are constructed by a priori concepts. Thus, the cognising subject has to see in mathematical outputs necessarily what it itself has placed into them. This insight is the precondition for mathematical knowledge to attain the secure path of science. Kant thus argues that the subject constructs the geometrical figure $a$ priori in the mind without relying on the outside:

For he [Thales] found that what he had to do was not to trace what he saw in this figure, or even trace its mere concept, and read off, as it were, from the properties of the figure; but rather he had to produce the latter form what he himself thought into the object and presented (through construction) according to a priori concepts, and that in order to know something securely $a$ priori he had to ascribe to the thing nothing except what followed necessarily from what he himself had put into it in accordance with its concept.

Kant, 1998:B xii

Similarly, in the history of physics, the revolution which was most important in allowing the field to establish itself on the secure path to science was not brought about by observation and analysis. For physics, the revolution, and thus the discovery of the laws of nature (the laws governing the material aspects of the phenomenal world), came about through the experimental method. Kant gives the honour of champion of the revolution in physics to Francis Bacon, since it was he who encouraged the experimental method. For Kant, physics is an empirical science, governed by empirical laws, which can be acquired by applying the experimental method (Rockmore, 2006:57). Kant illustrates this point by way of recounting the experiences of Galileo, Torricelli and Stahl:

When Galileo rolled balls of a weight chosen by himself down an inclined, or when Torricelli made the air bear a weight he had previously thought to be equal to that of a known column of water, or when in later time Stahl changed metals into calx and then changed the latter back into metal by first removing something and then putting it back again, a light dawned on all those who study nature. They comprehended that reason has insight only what it itself produces according to its own design.

Kant, 1998:B xii, B xiii 
By relating these examples, Kant makes a point that cognition has a similar role in the experimental method ${ }^{19}$ as it has in regard to the geometrical figure. In physics, calculations are applied which are derived from other experiments. The calculations thus derived through the experiment come to attain a status of universality and necessity. In mathematics, even before a geometric figure is drawn, it is constructed $a$ priori in the mind of the subject. "Thus I construct a triangle by exhibiting an object corresponding to this concept, either through mere imagination, in pure intuition, or on paper, in empirical intuition, but in both cases completely a priori, without having had to borrow the pattern for it from any experience" (Kant, 1998:B 741, B 742). Kant thus comes to the important conclusion that reason has "insight only into what it itself produces according to its own design" (Kant, 1998:B xiii).

This, in concert with the conclusions Kant learned from the empiricists and rationalists, means that reason cannot conform to the real world out there; rather, the phenomenal world - as it appears - must conform to reason. By understanding this limitation, metaphysics can aspire to find the secure footing of science. Moreover, Kant argued that reason does not approach the study of physics and its principles like a pupil, but "like an appointed judge who compels witnesses to answer the questions he puts to them" (Kant, 1998:B xiii).

Reason therefore is not only passive in the cognition of the phenomenal world, but also active, in that it places things in it which are its own subjective product. Kant thus concludes that the object must conform to the subject. Reason, Kant argued, is thus limited to the awareness and understanding of its own exclusive subjective product. As Kant put it: "From this it is clear that here reason could aim at nothing except its own formal rule in the extension of its empirical use, but never at an extension of it beyond all the boundaries of empirical use, consequently, that under this idea there does not lie hidden any constitutive principle for its use directed to possible experience." (Kant, 1998:A 686/B 714). Or in other words, it is not the

\footnotetext{
${ }^{19}$ For instance, reason can come up with theories, which lead humans to build devices which - since the knowledge they have constructed is actually flawed - have side effects unknown and undesired. For example, medicine, supposedly the result of sound knowledge about chemistry and the human body, often comes to have an unforeseen effect.
} 
objective reality which structures our minds, but it is the content of our minds which produces reality. The implications of this insight are far reaching. Kant's revolutionary contribution to metaphysics through his critique is the conclusion that humankind has access to a priori knowledge about the phenomenal world, since this world is not entirely independent from the human mind. The phenomenal world, in contrast to the world of noumenon which the mind may never know, is constructed by the human mind: it is the product of combining sensory input, which the human mind receives passively through sense organs, with a priori forms supplied by the cognitive faculties of the subject.

Knowledge is thus limited to aspects of the phenomenal world which reflect $a$ priori forms supplied by the subjects' cognitive faculties. In Kant's words, “we can cognize of things a priori only what we ourselves have put into them" (Kant, 1998:B xviii). In regard to the original aspiration of metaphysics, the Kantian argument thus means that we can only know what we construct, make, or produce as a necessary condition of knowledge. The world as it appears is thus not the true, real world as it exists in itself, but rather the appearance of the world as experienced by subjects and therefore relies on elements produced and constructed by the human mind.

This insight ultimately means that reality comes about by subjects drawing on concepts and forms which are constructed by subjects themselves. The appearance of reality is thus always conditioned by forms and concepts available to subjects a priori. As subjects come to cherish a changing set of concepts and forms, reality starts to appear differently to the cognising subjects. For Kant, concepts and forms are given by knowledge, which he, in a sense, understands as a universally valid body of truths. Let us look in the next section at the implications of this.

\subsection{The universalist approach towards the production of reality}

At the outcome of Kant's Copernican turn lies a constructivist approach to metaphysics (Rastovic, 2011:22; Rockmore, 2006:23). The object must conform to the subject. What this approach means is that we know what we construct. This understanding lies at the heart of postmodernism: 
This would be just like the first thoughts of Copernicus, who, when he did not make good progress in the explanation of the celestial motions if he assumed that entire celestial host revolves around the observer, tried to see if he might not have a greater success if he made the observer revolve and left the stars at rest. Now in metaphysics we can try in a similar way regarding the intuition of objects. If intuition has to conform to the constitution of the objects, then I do not see how we can know anything of them a priori; but if the object (as an object of the sense) conforms to the constitution of our faculty of intuition, then I can very well present this possibility to myself.

Kant, 1998:B xvi, B xvii

Kant's constructivist approach to epistemology thus stands in opposition to the approaches likened to direct realism and indirect realism, i.e. representationalism. Direct realism premises that we can acquire knowledge by directly drawing on the objective world as it is, "the world out there". Kant dismissed this approach as impossible. Representationalism claims that we can draw on the representation standing in between objects and subjects, and then by analysing these representations, we can learn something about the real objects they claim to represent. However, indirect (empirical) realism struggles to show that representations in fact represent what they claim to represent (Rockmore 2007:57).

Kant's constructivist epistemology, contrary to the hopes of direct and indirect realism, claims that we cannot come to know the objective world as it really is. Following the constructivist approach to knowledge, the subject cannot know the world as it is in itself, but only what the cognising subject can make, produce, or construct as a necessary condition of knowledge.

Kant recognises two approaches to gain knowledge about the world (Rastovic, 2011:2). First, epistemological representationalism, and second, epistemological constructivism: Kant touched on both of these approaches in correspondence with Marcus Herz, a friend and former student of his. Herz asked in a now famous letter, written in 1772: "What is the ground of the relation of that in us which we call 'representation' to the object?" (Kant, 1967:71) Kant explained, in reference to epistemological representationalism, that representations are in between the subject and the object, and that by analysing these representations, knowledge comes about as a dependable quality of the relation between representation and object. Thus we may learn something about the real world out there, but we can never be sure to what degree our findings are tainted by subjective elements. 
The second approach, which Kant came to articulate in the wake of his experiment, is epistemological constructivism (Rastovic, 2011:23). This approach is based on the insight gained by studying the history and workings of mathematics and physics. According to epistemological constructivism, we can know only what we construct; or rather, subjects construct the object as a necessary condition of knowledge. Kant thus denies that a subject can ever come to know the real world out there, the noumenon. However, that does not mean that the "real world out there" does not exist for subjects, or that it does not exert an influence on the process of reality production. In Kant's approach there is a metaphysical unity between things as they appear, phenomena, and things in themselves, noumenon (Kant, 1998:B xxi). This relation implies that knowledge which can be gained about the object is only true in relation to the subject: the subject constructs the object which is itself related to the subject.

This metaphysical unity consists of three broad elements (Rastovic, 2011:2324): First, phenomenon. A phenomenon is a representation of a representation - that which is immediately given to sense experience. It is the raw material from which the sense organs can extract the internal representations which then in turn are processed by the cognising subject. Second, appearance. Depending on how the cognising subject processes the incoming internal representations, phenomena attain a certain appearance. Appearance thus is the phenomenon as seen by the cognising subject. Third, noumenon. The noumenon is the "real world out there", the objective reality, things in themselves.

Reality, as experienced by subjects, thus comes about in the following manner: Phenomena, defined as representations of representations, ultimately inspired by objects located in the noumenon (a world subjects are unable to directly access), are the raw material which can be accessed by the human sensory organs (Rastovic, 2011:23-24).

The cognising subject then processes representations of the phenomena which the sensory organs make available by integrating them into concepts (which reason has produced, by drawing on knowledge, thereby producing adequate forms). What is 
produced in this process is the world as it appears. What this implies is that the cognising subject cannot know the world as it is itself because it is not able to experience it in a direct manner. The cognising subject thus can only know what it itself has constructed as a condition of its knowledge (Rockmore, 2006:88). Kant thus argues that the subject can affirm that the external world exists, but cannot know how it really is: "But this persisting element cannot be an intuition in me. For all the determining grounds of my existence that can be encountered in me are representations, and as such they themselves need something persisting distinct from them, in relation to which their change, and thus my existence in the time in which they change, can be determined" (Kant, 1998:B xxxix).

Kant names intuition and concepts as the basic conditions of knowledge: "But besides intuition there is no other kind of cognition than through concepts" (Kant, 1998:B 93). Kant explains that all concepts "rest on functions," and then elaborates: "By a function, however, I understand the unity of the action of ordering different representations under a common one.” (Kant, 1998:B 93). The cognising subject receives constant streams of material through the sensory organs, in various representations, which it then must integrate through the application of categories, i.e. the pure concepts of the understanding, into a single, coherent representation of the world out there. In other words, to unify different representations under a common one (Kant, 1998:B 93). Each such unity of many representations into a single one is a pure concept of the understanding.

The world as it appears thus is the result of the cognising subject integrating a representation of an object, which the sensory organs have made available, into the pure concept of the understanding pertaining to the object held a priori. Hence, we can only make sense of phenomena which constitute objects which we can integrate into adequate concepts, which in turn we derive from knowledge. Thus to be able to cognise an object, the subject requires proof of its possibility, either by experience or a priori (Kant, 1998:B xxvii).

However, Kant leaves the way open to an alternative (Rastovic, 2011:24). If the subject cannot cognise the thing in itself, the noumenon, Kant suggests that the 
subject can think about it (Kant, 1998:B xxvii). The imagination of subjects thus can give rise to transcendental illusions (Kant, 1998:B 103), images of the world which do not exist in the real world, but which are possible: "But I can think whatever I like, as long as I do not contradict myself, i.e., as long as my concept is a possible thought, even if I cannot give any assurance whether or not there is a corresponding object somewhere within the sum total of all possibilities" (Kant, 1998:B xxvi). By thinking, and guided by intuition, Copernicus thus was eventually in a position to bring about his Copernican revolution - for, as Kant implies, what can be thought can become true, as long as it is within conditions delimited by a priori knowledge.

The Kantian constructivist epistemology thus is able to show how reality and the appearance of reality is not the same. The appearance of reality is constructed by subjects which draw on concepts which are available a priori to them. As the beliefs which inform these concepts change, the appearance of reality changes correspondingly. This is the key assumption on which postmodernism is rested. This insight thus allows for the understanding of how, in world politics, interaction between states and other actors is not conditioned by material factors alone. Rather, ideas play a central role.

Whereas Kant focused specifically on knowledge as the source for forms and concepts, which subjects can draw upon when constructing the appearance of reality; as we will see in the chapter ahead, postmodernists argue that there is no universal knowledge which guides universal subjects; rather, it makes more sense to think of subjects resting on particular perspectives, beliefs, which are the outcome of assemblages of religion, knowledge, ideology and other systems of belief. Beliefs, not knowledge, are thus the source from which subjects derive concepts and forms. Moreover, since Kant thought of his problem in terms of the state of metaphysics in relation to humanity, he did not consider the question of power in shaping the source of forms and concepts. Once we do change perspective, away from the universal perspective given by thinking about human kind, towards particular perspectives as experienced and given to subjects when thought of as individuals, we come to understand that power plays a central role in shaping beliefs. Indeed, the relation 
between power and belief, as we will see, comes to constitute a core aspect of postmodern understanding of the workings of the world. 


\section{The postmodernist turn}

Kant ended his inquiry into the relationship between reason and reality as an optimist. He had defined metaphysics as "the inventory of all we possess through pure reason, ordered systematically" (Kant, 1998:A xx). He thus concluded that progress would come through time, if humanity approached the problems of the world in a concerted effort, keeping in mind the limitations he had set out. In other words, by employing reason steadily and being mindful of the triangular relation between phenomena, noumenon and appearance (Rastovic, 2011:23-24), mankind would eventually come to find the solutions to all problems. Kant thus says that mankind, as the universal subject, could come to obtain universal knowledge, by studying the problems of the world through a universal perspective.

In the tradition of western philosophy, the Kantian insights attained a position of hegemony, in that no one was able to dispel his conclusions (Schrift, 2010a:15). Post Kantian philosophy gave rise to several further strains of philosophy. One strain accepted Kant's conclusions that there is a gulf between the object and the subject, yet - with these limitations in mind - was set to continue to peruse the ideal held by the champions of reason during the Enlightenment (Hicks, 2004:44). This strain of philosophy came to be known as neokantianism, and would lead eventually to structuralism in the social sciences in general, and to neorealism in the field of international relations.

As the 19th century unfolded, through neokantian approaches, reason came to structure ever wider conceptual frameworks underpinning the ordering of spaces of social interaction (Schrift, 2010c:47-85). Approaches to government, to the organisation of the economy, to interstate relations all came to be reformulated so as to conform to the requirements of reason. At the same time it was maintained that it is possible to understand the world as it is through empirical means, which in turn allows one to harness the power of reason, and to articulate universally and necessary insights about the social world. Thus, in a way, the Enlightenment dream of a world marked by beauty, justice and freedom continued uninterrupted. Through ever more refined methods, these positivist social scientists argued that universal truths could be 
extracted from the social world. These could be studied, and then give rise to new modes of conduct. Indeed, today, mainstream interpretations of the free markets and liberal democracy, the foundation of the modern social world in the West, are direct outcomes of the continued confidence in reason and its ability to structure human existence in accordance with its premises (Hicks, 2004:23).

In the wake of the Second World War, neokantianism attained a position of hegemony in the social sciences (Knutsen, 1998). With Europe in ashes, the United States became the most important centre for academia. In the US, social scientists at the University of Chicago pioneered social science approaches which claimed to be inspired, in terms of method, ontology and epistemology, by the natural sciences. Friedmanite economics and neorealism are both outcomes of neokantianism. They thus continue to suffer from the same problems Kant had already encountered when looking at the empiricist and rationalist debates of his time.

\subsection{Perspective as a condition for knowledge}

Not everyone, however, shared Kant's optimism. Sceptics who followed in the path laid out by Kant asked questions such as: How can the subject be universal, if individual subjects have identities, different from one another? How can the world be studied from a universal perspective, if individuals look at the world from different positions? And how can a universal body of knowledge therefore be put together, if different subjects put together different respective bodies of knowledge, serving as the bases for concepts and forms corresponding to their own perspectives? (Rosenau, 1992:14-16)

As Kant had suggested that the perspective must be changed when looking at the problems of metaphysics (inspired by Copernicus), the sceptics now in turn argued that a further change of perspective must be performed. The universal must be discarded, and replaced by the particular. The thinker probably most associated with perspectivism is the German philosopher Friedrich Nietzsche. Nietzsche denied that there is a universal perspective, affirming that "today we are at least far away from 
the ridiculous immodesty of decreeing from our angle that perspectives are permitted only from this angle." (Nietzsche in Molloy, 2006:2)

Mankind has lost the "real world" and the "“apparent world", Nietzsche wrote, arguing that there is no universal, absolute truth. For, as he suggested, there are no facts to be grasped, only interpretations which depend on perspective (Spinks, 2003). Nietzsche's 'perspectivism' essentially implies that truth is perspectival, as is knowledge that corresponds with truth. Nietzsche viewed interpretation as the essential condition of human existence. Subjects attain meaning of their existence through constant practices of interpretation. These interpretations are performed from particular perspectives. The practice of interpretation, and thus the creation of meaning, therefore does not happen from the universal position, but rather from the particular position.

How far the perspective character of existence extends or indeed whether existence has any other character than this; whether existence without interpretation, without "sense," does not become "nonsense,"; whether, on the other hand, all existence is not essentially actively engaged in interpretation.

Nietzsche and Kaufmann, 1974:336

Hence, there is no absolute, Nietzsche declared. Being is always in the process of becoming. Human experience is thus fluid, rather than fixed. For instance, regarding the concept of "good": In a distant past, this concept suggested nobility and strength. Later it came to imply submission and weakness. Nietzsche thus argued that there is no unconditional ground for reality, no absolute perspective, only a plurality of forces which form themselves into groups, constantly breaking apart and reforming into other combinations. Truth and knowledge thus depend on perspective (Hart, 2004:37).

If we go back to Kant, and reconsider his assertion that "we can cognize of things a priori only what we ourselves have put into them" (Kant, 1998:B xviii), when we must come to the conclusion - in the light of this change of perspective that subjects construct particular sets of beliefs, from which they derive the concepts and forms which allow them to see the world as they see it. For, as subjects employ particular perspectives, they need corresponding concepts to make sense of the world as they see it. Truth about the world is thus conditioned by the perspective employed. 
If we accept this change of perspective, the process of the production of reality becomes more fluid and open as in the Kantian mould. The cognising subject processes incoming representations, which are conditioned by the position the subject occupies, by integrating them into concepts which must correspond with the perspective taken by the subject. Knowledge thus cannot be universal and necessary, since different perspectives produce different knowledge. The fact that groups of subjects nonetheless come to accept common truth, according to Nietzsche, lies in the outcome of struggle between perspectives, where the powerful exercise their strength and are able to establish their particular perspectives as the dominate one, the perspective of truth.

Insofar as the word "knowledge" has any meaning, the world is knowable; but it is interpretable otherwise, it has no meaning behind it, but countless meanings.--Perspectivism." It is our needs that interpret the world; our drives and their For and Against. Every drive is a kind of lust to rule; each one has its perspective that it would like to compel all the other drives to accept as a norm

Nietzsche and Kaufmann, 1974: 481

A certain consensus of perspective comes about when concepts, which Nietzsche calls chains of metaphors, are hardened into generally accepted truths. According to Nietzsche, a metaphor begins when a nerve stimulus is reproduced as an image, which is then codified in sound, giving rise to a word. The word becomes a concept when that word is used to designate phenomenological objects, i.e. "things" out there, with which the subject is confronted in its existence in the social universe. The competition between interpretations for the status of truth is thus governed by relationships of power. Interpretations must struggle against one another. Truth can emerge when weak interpretations are exposed and strong interpretations prevail, in the context of a swirling universe of interpretation. Subjects thus come to position themselves in relation to the truth they accept; and conversely, the position subjects take leads them to adhere to a corresponding truth'. (Molloy, 2006:9)

In sum, we reiterate that individual subjects cherish individual beliefs. These beliefs are conditioned by assemblages of systems of beliefs, such as religion, knowledge, culture and other systems. Each individual subject may come to see certain things in particular ways. What subjects believe to be true is conditioned by the perspective they uphold in relation to the social world. However, in certain 
matters of interest to power considerations, subjects may be forced (directly, or indirectly) to take a perspective desired by groups of powerful subjects. These perspectives, which are encouraged and furthered by groups of subjects possessing relatively greater subjective power than others, come to attain the status of universal, in that they are accepted by all to be true. However, they ultimately may never be universally and necessarily true, and can therefore be reassembled through the use of subjective power. Thus what is true in one spatiotemporal configuration may be untrue in another spatiotemporal setting. We can all think of examples in our own lifetimes, where many years in the past things were said to such and such, whereas today we understand them completely differently.

\subsection{Postmodernism, power and truth}

After Kant, continental philosophy, the branch of philosophy which followed in the direction Kant had pointed to, brought forth a number of schools (Schrift, 2010a:1-15). As we have seen, neokantianism accepted the gulf between the object and subject, yet - with these limitations in mind - sought to continue on the course set out by the champions of the Enlightenment (Schrift, 2010c:47-85). In doing so, neokantianists claimed that it is possible to uncover universal and necessary truth about reality (whereby reality is now linked to the phenomenal world, while the noumenal world is left to its own devices).

The point about this approach is that cognising subjects always come to see the same appearance of reality, as they integrate representations of the phenomenological world, as seen from a universal perspective, into concepts and forms which are derived from a universal body of knowledge. However, Nietzsche argued that there is no universal perspective, and that as such, there is no universal body of knowledge (Spinks, 2003:37-38). This implies that a cognising subject integrates representations of the phenomenological world, which are conditioned by the position the subject takes up, into concepts and forms which must correspond with the subject's perspective, and which therefore cannot be derived from a universal body of knowledge. Rather, as postmodernists come to argue, the process of production of 
reality involves beliefs, which can be understood as assemblages of ideational structures such as religion, knowledge, ideology and so forth.

The Kantian constructivist epistemology, and the perspectivist argument of Nietzsche, thus stand at the outset of Postmodernism (Aylesworth, 2015; Rosenau, 1999; Hart, 2004). Postmodernism is hard to describe in unitary terms, since the school refuses to see itself as a coherent body of ideas. What the members of the school agree on, however, is that they accept the basic Kantian understanding that the subject constructs the object and that reality and appearance are therefore not the same thing. They also agree with Nietzsche's perspectivism, according to which truth depends on perspective and therefore many truths exist simultaneously; appearance is thus the outcome of power relations, and not given by any ultimate, absolute grand narrative (Hart, 2004:20).

Postmodernism follows in the tradition of antifoundational philosophy (Hart, 2004:37). Antifoundational philosophy asks questions such as: "What guarantees that your perspective on the truth is valid?" Postmodernism can thus be seen as a form of scepticism (Rosenau, 1999:12-24). Postmodernists question any claim to truth and certainty (Sim, 1998:3). In a way similar to classical realism - which looks back to the pre-realist past in identifying its fathers in Machiavelli and Hobbes postmodernism finds many parents in the modernist past. Nietzsche, with his call for the re-evaluation of all values, is a canonical thinker, as is Marx with his early ponderings on the link between power and knowledge.

In the West, where postmodernism was born, the school has come to prominence by rejecting the cultural certainties in which knowledge has come to be structured over the course of modernism, a movement which is traced back to the renaissance, and which is built around the premise of reason (Sim, 1998:3). Postmodernists have called into question the western commitment to progress, and have challenged the political systems which supposedly underpin this belief (Rosenau, 1999:43). Postmodernists focus their criticism heavily on the Enlightenment project, specifically the liberal humanist ideology and her main offspring, liberalism and capitalism, which have come to dominate western culture since they were unleashed 
in the late 18th century (Hart, 2004:17). Postmodernists argue that the Enlightenment project had once promised a world of freedom, liberty, equality, progress - a world free of material want and political oppression, yet that it had failed to deliver. Indeed, it had become a system of oppression itself, forcing certain modes of thought and conduct on the subjects within its reach. Postmodernists are thus critical of all discourses which lead to power hierarchies in the social spaces they organise. Indeed, the role of power in the construction of appearances is one of the core areas of study for postmodernists.

In the social sciences, postmodernism came alive in reaction to the rise of structuralist theories (Sim, 1998:4). Hence the term poststructuralism. Structuralists were essentially neokantian in that they accepted the limits set out by Kant, yet focus on finding the truth within the universal dimension of the phenomenal world, while leaving the noumenon world to its own devises. Structuralism was a school inspired by the Swiss linguist Ferdinand de Saussure, who revolutionised the discipline of linguistics in the early 20th century (Tyson, 1999:190).

Saussure's insight about language was that it could be conceptualised as a system, in which grammar - a framework of rules and regulations - governs how the many elements of language operate. According to Saussure, words are essentially signs. Each sign is made up out of two parts: signifiers (the written or spoken word) and signified (concepts). United through a mental act, they form a sign. There is no natural connection which brings signifiers and signified together. Rather, as Saussure admitted, this connection is arbitrary: a force of convention by the users of the language ensures that words, or rather, the constellations between signifiers and signified, do not change randomly.

Saussurean structuralists thus argued that there is a relative stability to language and the production of meaning, and that language can be understood as a system of signs which allows for the uncovering of predictable patters and outcomes. The Saussurean linguistic model came to form the basis of structuralist analysis. Structuralist analysis premised that every system in general is based on internal grammar which governs its operations. Hence, argued Suassurean inspired 
structuralists, by uncovering the internal grammar of systems - be they tribal rituals, the advertising industry, literature, fashion, or anything else which could be understood as a system - it is possible to find the real truth governing the systems in question.

One of the most famous structuralists was Claude Lévi Strauss, the father of modern anthropology. Lévi-Strauss, by studying "tribal" people and their particular cultures, became interested in the apparent paradox he saw in myths (Lévi-Strauss, 1963). One the one hand, he found, mythical stories are fantastic, unpredictable and seemingly arbitrary. On the other hand, the concepts of different cultures underlying their respective myths are surprising similar:

It would seem that in the course of a myth anything is likely to happen. There is no logic, no continuity. Any characteristic can be attributed to any subject; every conceivable relation can be found. With myth, everything becomes possible. But on the other hand, this apparent arbitrariness is belied by the astounding similarity between myths collected in widely different regions. Therefore the problem: If the content of a myth is contingent, how are we going to explain the fact that myths throughout the world are so similar?

Lévi-Strauss, 1963:208

Lévi-Strauss thus concluded that universal laws govern mystical modes of operation, hence myths and corresponding practices have come to be marked by certain similarities throughout mankind (Sim, 1998:5). In other words, each myth merely appears unique, yet is actually just a particular instance of a universal law governing human thought. In his studies of myth, Lévi-Strauss attempted to filter the apparent arbitrary data he gathered from different cultures, and strove to find universality and necessity in human practices. He thus concluded that all human beings are governed by the same set of underlying desires, aspirations, hopes and fears, and that what appeared different was but a variation of the same underlying theme: the universality of the human being.

For Claude Levi-Strauss, as well as for Roland Barthes (another French philosopher who later turned away from structuralism), every detail of the narrative they analysed was significant in terms of identifying the underlying structure (Sim, 1998:5). By narrative they came to understand a discourse articulated from a particular position. Everything could thus be seen as a narrative: tribal myth, fashion, literature, and so on. Once the grammar governing the system is unlocked, truth can 
be found. Following through this argument, one system comes to seem much like any other system, and the deciphering of its grammar becomes a predictable exercise. However, not everyone was happy with the premises that structuralism came to state. Those later known as the poststructuralists argued that the techniques employed by structuralists determined the results, and that thus the apparent universalism seen by structuralism was in fact of its own creating. Moreover, they believed that structuralism, in the way it was formulated, cannot account for creativity, chance or the unexpected.

Only by shifting the perspective away from universalism, towards a perspective which can account for plurality - so the poststructuralists argued - could structuralism make sense when applied to the problems of the world (Mills, 2003:2). For poststructuralists, creativity, change and the unexpected are of key importance, not least because the role of power in relation to appearance and reality can be uncovered only by abandoning universalism and objectivity (Hart, 2004:26-27). It is this move in the social sciences which led to a break between the positivist approaches - mostly developed in the universities of the United States - and the postmodern and critical approaches, which were in many instances pioneered in Europe but then also picked up in America. Jacques Derrida's deconstruction, a critical approach concerned with textual meaning, became one of the most powerful and famous expressions of the postmodernist sceptical view of structuralist claims towards universality (Royle, 2003:21-31).

Deconstruction was directed against system building approaches implicit in structuralism, as well as against the claim that every appearance can be deciphered by looking for the grammar, and that thus universality is given, allowing mankind to aspire for total control of all aspects of social existence. Derrida identified weaknesses in language and in systems in general, which he hoped to demonstrate in his work "Of Grammatology" (Royle, 2003:71-78). In Derrida's view, signs are not the predicable, stable entities as claimed by the Sassureans. Indeed - and this was a central point to Derrida - signifiers and signified are never perfectly fused together, and are therefore not able to guarantee consistent stability, so as to enable unproblematic communication. Rather, some "slippage", as he called it, would 
always undermine the true meaning of given words. Derrida aims to demonstrate "slippage" through "différance", a neologism he derived from the French word "différer" which can mean both difference and deferral. Through the creation of the word "différance", Derrida makes a point that when spoken in French, the word cannot be differentiated from the word "différence", which sounds identical, but differs in meaning. Only in written form, the distinction can be marked out.

For Derrida, this experiment reveals the inherent indeterminacy in meaning. Words, as arbitrary forms, need to be able to refer to other words, while differing from yet others, so as to make sense. Every word has a meaning in the context of others. As words change over time, all other words in the grand sea of context must also change. Derrida concludes by arguing that linguistic meaning is always unstable; meaning, and the objects words claim to denote, may always slip apart. Meaning, and thus truth, only exists in momentary spatiotemporal configurations, and evaporates almost immediately when conditions change, as it transforms itself into something new (Royle, 2003:78).

Meaning is thus not fixed in space and time and is not identical to different generations of audiences throughout time. Derrida claims that all Western philosophy is based on the assumption that the full meaning of a word is "present" in a speakers mind, and that a narrative can thus be communicated to an audience without any significant slippage. For Derrida however, this "metaphysics of presence" is an illusion: "différence" always undermines communication, and therefore denies the establishment of completeness of meaning. The emphasis on difference - on that which fails to conform to the norm of systemic approaches - is a central ethos of postmodern philosophy, and is thus to the denial of the existence of a universal ordering principle for human existence.

The thinker who first used the term postmodern, and who contributed decisively in understanding the implications of the insights of postmodernism, was the French philosopher Jean Françoise Lyotard (Malpas, 2003). Lyotard, in his early life, was a Marxist. He was part of a group called "Socialism ou Barabrie" (Socialism or Barbarism), through which he participated in public debates. During the Algerian 
war, he looked at events through his Marxist perspective, and in the process, as the drama unfolded, he became disenchanted with the premise of Marxism. He came to see Marxism as "a grand narrative", as he called it. As a pioneer of postmodernism, the critique of all grand narratives became the focal point for Lyotard throughout his career. In his most influential work, "The Postmodern Condition: A Report on Knowledge" (1979), he argues that knowledge is the world's most important commodity. He who controls knowledge, controls the political conditions of possibility. Or in other words, he who controls knowledge, controls power (Malpas, 2003:15-30).

Lyotard argues that knowledge is communicated by means of narratives, and that so-called grand narratives play a special role, in that they order all other narratives in accordance with a rationale which claims to be the secure path to truth (Malpas, 2003:24-28). A grand narrative can be seen as a theory which claims to explain everything, which resists any attempt to change its form, and thus approaches the unfolding of the social universe, as Kant put it, "like an appointed judge who compels witnesses to answer the questions he puts to them" (Kant, 1998:B xiii). Lyotard explains what he means by analysing how his own relationship with Marxism played out. He argues that in Marxism there is a particular narrative of world history which the school claims to be true and beyond necessity of revision. Historical events or changes in culture do not mandate criticism or adaption, for the school claims that Marxism is in possession of timeless truth whose authority must never be questioned. Lyotard, in light of what he saw in Algeria, which contrasted with what orthodox Marxist theory would have predicted, argued that there must be reform. He argued that the Algerian peasant society had little to do with the Marxist concept of the proletarian, and thus advocated for pluralism and not universalism in the underlying epistemology. He was denied. For Lyotard, such an attitude was one of authoritarianism. This became an important insight into the understanding of the link between knowledge and power - power orders knowledge, and knowledge enables power (Malpas, 2003:31). 


\subsection{Postmodernists on power and reality}

Whereas pre-modern approaches seeking to explain the ordering of the social world are rested on God as their organising principle, positivist social science approaches employ reason as the fundament which supposedly orders the social world. However, both have in common that they assume that the subject is ultimately structured by the object (Hicks, 2004). Postmodernists, conversely, argue that it is the subject which structures the object. This means that reality as it appears is actually produced by the cognising subject. Postmodernists conceptualise this process by understanding the production of reality as the outcome of a process whereby the cognising subject integrates representations, derived by sense organs from the phenomenal world, into concepts and forms given by beliefs cherished a priori by individual subject.

The term "belief" is of key importance to this dissertation. In postmodern writings, the relationship between power and knowledge is often discussed, and understood to be a central question of our times (Mills, 2003:67-79). Knowledge is a far narrower concept than belief. For postmodernists, knowledge is not necessarily defined - in the Enlightenment sense of modern science - as the sum of what is known by systematic means of inquiry, the universal body of truth about the world acquired by humankind (Rosenau, 1999:41). Rather, for postmodernists such as Michel Foucault, knowledge is never definitive and given, but instead is reflective of power (Mills, 2003). For Foucault, power is based on knowledge and makes use of knowledge; while conversely, power reproduces knowledge by shaping it in accordance with its designs. However the definition, whether postmodern or positivist, knowledge is thus understood to be something which is, at least in a limited sense, built on claims about insights derived from the social world as it supposedly is in itself. Knowledge thus is articulated as a relation between the subject and the object.

Thus, whether we adapt a very strict definition as given for instance by the philosophy of science, or adapt a rather open definition as preferred by postmodernists, we always end up with a term which denotes relations to the phenomenal world (Pritchard and Turri, 2014). In one sense, this means that 
knowledge is power in that it allows for mastery of the material world: For instance, the US army is the strongest military force in our world, because it is equipped with the most advanced weapons systems (knowledge translated into military technology), but also because the plans which define how these weapons are deployed (knowledge about how to organise material factors in a spatiotemporal setting) are the most sophisticated.

However, such an understanding of knowledge means that there is no space for conceptualising how other ideational factors come to influence subjects. Yet considering what we have pondered until here, we affirm that ideational factors such as identity, ideology or religion do have an important role in informing subjects on the social world in which they are set (Bourdieu and Wacquant, 1992). For the purpose of this dissertation, it is thus preferred to think about beliefs, rather than knowledge, although there is certainly a strong relation between the two and it could be argued that a postmodern understanding of knowledge comes close to the broader understanding commonly associated with the term "belief".

The term belief is broader and more ample (Schwitzgebel, 2015). We believe whenever we assume something to be true about the world. To believe something, in this sense, does not involve critical reflections, nor manifestations thereof on the social universe. Nor do beliefs rest on empirical means. We may believe in a religion, or a certain ideology. There is no immediate proof for the validity in our social universe, yet nonetheless these beliefs structure our lives in the social world.

However, subjects do not come to adhere sui generis to a set of beliefs. But rather, what beliefs a subject cherishes is the outcome of conditioning performed by surrounding factors (Dean, 2010). These factors may include the family, the local community, the state, or even the international community. All have their perspectives on what constitutes true and valid beliefs, and thus aspire to condition subjects within their reach in accordance with the beliefs understood to be worthy. As a subject grows up and lives its life, it comes to adhere to many different beliefs. Beliefs are thus assemblages of knowledge, religion, ideologies, identities, culture and other ideational factors. Ultimately, each and every individual subject has a 
particular constellation of beliefs (Bourdieu and Wacquant, 1992). In many areas, it does not matter to other subjects, or to the social world in general, what beliefs an individual subject cherishes. In other areas, however, the agreement on a common belief is imperative. For instance, when organising systems of road transport, it is important that all subjects agree on which side of the road to drive, or when to stop and when to accelerate.

A relation of power and beliefs is thus always given. Firstly, in the sense that powerful actors always aspire to condition subjects within their reach in accordance with desired beliefs (Dean, 2010). Secondly, in the sense that beliefs delimit what power can do legitimately, and indeed should do (Mills, 2003). To illustrate the former: The parent conditions the child, the state conditions the subject, the international community conditions the state. Often this process of conditioning involves struggle, as subjects are within the reach of several actors: for instance, a socialist mayor wants to condition the subjects within his reach in accordance with socialist inspired beliefs, while the conservative federal government is keen to promote beliefs inspired by conservatism. To illustrate the second point, i.e. beliefs delimiting what power can legitimately do: in a feudal society, it is accepted that a few are in control of most of the material factors available. In an open and free society, such a state of affairs is not so easily accepted. In times of war, it is accepted to make use of weapons; in times of peace, this is not the case.

It is possible to imagine that the subjective thus completely dominates the objective - i.e. ideas completely structure human existence, as some postmodernists argue (Rosenau, 1999:14-18). However, it makes more sense to think of this relation in the terms of Pierre Bourdieu: Bourdieu argues that subjective beliefs dominate the way subjects experience the social world, yet that subjective beliefs must always conform to material factors. In other words, what is imaginable is constrained by the material reality “out there” (Bourdieu and Wacquant, 1992:11).

The implications of these insights are far-reaching. Through postmodernist approaches to social science theory, we come to understand that what we think is reality, is in fact merely subjective: conditioned by beliefs which in turn come about 
as a result of power, competition, and struggle (Easthope, 1998:18-20). From this assumption follows that actors can aspire to influence and shape the appearance of the social universe by deploying strategies and tactics, targeting instances sensitive to power, which are integral in the process of the production of reality. Once operations in these theatres are successful, reality, as it appears to the subject, is transformed (Bourdieu and Wacquant, 1992:14). In other words, it is possible, through subjective power, to change the beliefs that subjects cherish. Once such a thing is done, targeted subjects come to cognise the reality as it appears to them in different terms. This happens because the concepts and forms available to subjects, when engaging in the process of production of reality, are changed in accordance with the new beliefs as cherished by the subjects in questions. 


\section{Realism}

In chapter two and three we came to understand that appearance of reality is something that depends on relations of power and belief, and that thus by interfering with beliefs, the appearance of reality - and the power relations therein - can be changed. Yet what does this mean for world politics? Or more specifically, what does this mean for realism as the dominant school of international relations? Before we engage this question, it worth remembering that neorealists and classical realists share the assumption that actors employ reason in guiding their actions in the social universe. Realists claim that the ultimate demand of reason is survival, and that actors are thus compelled to concern themselves with considerations of power, for only sufficient levels of power can secure survival.

In mainstream approaches to realism, which favours neorealism, actors have to concern themselves mainly with material considerations, since, in the view of neorealism, material considerations are what matter in terms of power. However, if we accept the insights of postmodernists, and thus the premise according to which ideas (beliefs) play a role in matters related to power, then by logical inference we can assert that it would be reasonable for actors concerned with survival to take into account the domain of beliefs.

However, given its constrained epistemological and ontological commitments, neorealism is unable to understand the role of ideas, and thus remains limited to looking at material considerations. Due to the dominance of positivist approaches to the social sciences over the last three decades, the role of ideas in world politics has been relatively neglected, and scholars and policy specialists under the influence of neorealism have thus been unconcerned with ideational factors - or rather, have not been able to grasp the importance of them.

Such an attitude among scholars and policy makers has not always been the case, as is clear when reading closely the works of so-called classical realists. Classical realism understands the importance of belief in questions pertaining to power, and thus is concerned with the factor of ideas in world politics. We start this 
chapter by looking at the history of realism and how realism is understood in classical and contemporary mainstream interpretations of the social sciences. After considering the core claims and concepts of realism, we reconsider them in the light of postmodernism. By looking at relations between power and beliefs, we come to understand how subjective power works in world politics.

\subsection{Realism as a theory of international relations}

Realism is a term that is used in a variety of ways across different fields. In the context of metaphysics, realism denotes the claim that the real world can be grasped and understood as it is in itself. In art and literature, realism is about reproducing the appearance of reality as faithfully as possible (which is impossible, since the artist's perspective is inevitably biased). In the field of international relations theory, realism represents a traditional approach to the study of world politics which stresses the imperative of power driven struggle among actors who share a common existence in anarchy - a space absent an all ordering power. The way the term realism is used in different areas is not driven from one single agreed perspective, and so the insights gained in one area do not necessarily carry implications for other areas. (Donnelly, 2005:29)

In the field of international relations as an academic discipline, the paradigm of realism has been present as a central approach to theory since the inception of the school in the aftermath of the Great War. At the outset, liberal approaches to international relations theory were encouraged by popular opinion and elite establishment alike. Billionaire-philanthropists such as Andrew Carnegie, and large pro-peace crowds enthusiastically taking to the streets, both called for liberal modes to knowledge production (McGann, 2011; Abelson, 2006). It was hoped that the secure path to peace and prosperity could be found in the liberal tradition of thought. This optimistic perspective claimed that peace could be achieved through cooperation. Cooperation would be possible through the League of Nations, the formal expression of the groundbreaking international institutional order which the American president Woodrow Wilson established almost singlehandedly. In the League of Nations, states 
could come together and discuss and debate pressing issues for world politics. Security was now an issue of collective concern (Knutsen, 1997:209-214).

Realism, as a theoretical approach, in this early stage of the history of international relations theory, constituted the intellectual antithesis which had to be overcome by the scholars dedicated to liberalism. Indeed, the early generation of international relations scholars saw Realpolitik - a practice of politics conducted by the statesmen of Europe in the second half of the 19th century, epitomised by the German and Italian statesmen Otto von Bismarck and Camillo Cavour respectively as the origin of a dynamism which eventually had culminated in the Great War.

Yet as the post-war order failed to usher in a united world in the 1920s, and then unravelled ever further in the tumultuous 1930s, critics, such as British diplomat-scholar E.H. Carr, argued that the inability of world politics to find tranquillity and stability was due to the flawed premises inherent in what Carr came to call the idealist school of international relations (Molloy, 2006:16,26-30). Carr's critique, published in his book "the 20 years of crisis", was directed at idealism, which he understood to constitute the hegemonic perspective in international relations. The book marked a key moment for realism in international relations, and it is frequently seen as the moment when realism was born as a school in its own right. Hans Morgenthau, a German scholar who fled to the United States after the Nazis took power in the early 1930s, and who came to fame and influence in his field of study, subsequently went on to further develop realism as a school of international relations (Williams, 2005:3).

This group of early realists, which included other scholars, such as American Diplomat George Kennan and scholar-theologian Reinhold Niebuhr, argued that realism as an approach to politics had always existed, and that the insights of realism can be seen as a critique of politics in the context of power and anarchy (Molloy, 2006:35-45). In the search for eternal insights about power politics, they looked towards the writings of a series of authors who were part of the historical European political tradition. The Athenian historian Thucydides, the Florentine diplomat Niccolò Machiavelli, the English philosopher Thomas Hobbes and the Prussian 
general Carl von Clausewitz were all identified among many others as having come to discover basic insights about the workings of power, relevant to those who dedicate themselves to the practice and study of world politics (Knutsen, 1997:240241; Donnelly, 2005:30-31).

These founding fathers, together with those thinkers whom they identified (and established) as canonical, came to be known as the classical realists, and their school, that of classical realism. However, whereas academia came to speak only recently of classical realists and classical realism, there is, as Donnelly stresses, not one single universal and necessary concept underlying these terms. In other words, there was no generally agreed upon universal definition. Classical realists differ in their definitions and understandings, and different writers stress different aspects of power politics (Donnelly, 2005:30). In some areas they may disagree in what they observe, in other areas similar observations may lead to differing conclusions. Yet what brought them together under the label of classical realists was the emergence and rise of the positivist interpretation of realism: neo-realism.

Neorealism claimed to be different from other approaches in that it was scientific - articulated in the discourse of the philosophy of positivist natural science, and based on corresponding ontological, methodological and epistemological commitments. In reflection of its dominance in the social sciences, achieved during the 1980s, neorealism came to occupy the signifier of realism, while earlier nonpositivist interpretations came to be known as classical realism. (Donnelly, 2005:35) Although still dominant in the overall mainstream context, neorealism has in recent years lost some of the prestige and influence it once enjoyed. This is due to the waves of aftershock which have destabilised neorealism ever since the so-called Fourth Debate, when the proud and powerful neorealist establishment suddenly saw itself confronted with formidable and seemingly insurmountable criticism (Krause 1999; Schweller, 1996).

The term "Fourth Debate" is somewhat confusing, since it implies that there was a moment in time when the debate started, and when it ended. The debate emerged in the mid-1980s, and pitted rationalism (more precisely neorealism) against 
critical approaches to international relations theory. There was never an official moment when the debate was declared over, and for a long time it looked like the positivist approaches, and thus neorealism, would simply continue - and even expand - their positions of dominance in the social sciences. Indeed, neorealism went on to dominate policy in the United States and then Europe and elsewhere (Knutsen, 1997:278-282).

Slowly and steadily, however, aftershock after aftershock kept undermining neorealism's claim to universal and necessary truth. Partly responsible for the fall of neorealism are the many moments in history which were not foreseen by the theory. The end of the Cold War, the rise of non-state actors, the non-return of power politics to Europe are just a few among many other examples. But that is only part of the story, for on the theoretical side of the debate, neorealism saw itself progressively unable to counter the arguments originating from among postmodernists, critical theorists and others from the surging critical security studies community (Krause 1999; Schweller, 1996).

\subsection{Defining realisms core concepts and assumptions}

Not surprisingly, specialists on realist theory of international relations agree that there is no one definition of realism (Donnelly, 2005:30) (Molloy, 2006:6). Donnelly, however, argues that although definitions of realism vary, many of the recognised IR brands of realism nonetheless share a certain family resemblance, a distinctive and recognisable flavour.

Most realists recognise that human nature eventually is a factor conditioning world politics, and the power politics therein. These realists emphasise human nature as a limiting factor on the conduct of world politics; they see in human nature an enabler - or even facilitator - of conflict. Most realists ground this assumption in human nature, which they argue is fundamentally selfish (Donnelly, 2005:30). Those realists who consider subjective dimensions of power understand the locus thereof to be eventually found in human nature (Molloy, 2006:31-32). 
The other crucial assumption is anarchy. Anarchy comes about as the result of the absence of one all-overpowering (legitimate) force. Hence, all actors may equally be permitted to hope to construct the destiny they deem exclusively for themselves. Yet scarcity of desirable things prevents each actor from having as much as is perceived to be necessary in reaching desired ends. Even considering that some may accept that they cannot have more than they have already, others, committed to achieving their ends no matter the means, and unhindered by a single ordering authority, may always take what nature allows them to take. As a result, actors can never be assured about their security; indeed, they become enemies to one another. Realists agree that anarchy is the main structural force conditioning human existence (Donnelly, 2005:30-31;Molloy, 2006:32-33).

Rationality is a further common core premise of realism. Competing actors employ reason in cognising world politics and draw on it in orienting their actions and strategies, which - as a critical concern demanded by reason - must aim to secure power in sufficient quantities in order to guarantee survival.

Within states, where there is clear political order, with the state standing on top of a power hierarchy, egoism is substantially restrained. In international relations, where there is no overarching power unit governing all, the anarchy that follows allows for the worst aspects of human nature to come to the forefront. Statesmanship in the international context thus means mitigating and managing conflict, or neutralising conflict wherever this is impossible. Seeking the least dangerous world possible, rather than a safe, peaceful and just world, is what the realist argues is the sensible position, even though this might bring about disaster for all. (Donnelly, 2005:31). Consequently, this must mean that ethical considerations must give way to 'reasons of state' (raison d'état). In other words, the state must do everything so as to secure adequate power for the overarching goal of survival: "Realism maintains that universal moral principles cannot be applied to the actions of states" (Morgenthau 1973:9). 


\subsection{A traditional reading of Thomas Hobbes 's realism}

As we have seen, the relationship between anarchy and human nature, and the resulting world in which power struggle is an endemic condition, lie at the core of realism (Donnelly, 2005:30-31). Arguably the most important foundational thinker of realism, who defined many of the terms and concepts in which realism is thought of, is Thomas Hobbes. Since we will perform a close rereading of classical realism, by focusing mainly on the English writer, we will first reproduce a traditional interpretation of Thomas Hobbes' Leviathan (1904).

Originally published in 1651 (Williams, 2005:19), in this work Thomas Hobbes provides an extraordinarily vivid and detailed account of an imagined pre-social state of nature in which subjects, absent an ordering power, seek to coexist. The resulting image gives rise to a concise theory of classical realism, which gives approximately equal weight to human nature as it does to anarchy, in considering the nature of conflict. Accepted as foundational by realists of all colourings, the Hobbesian state of nature offers paramount insight into some of the most central problems of international relations (Donnelly, 2005:32).

Hobbes makes three key assumptions about social life in the state of nature (Donnelly, 2005:32):

1. Men are equal.

2. They interact in anarchy.

3. They are driven by competition, diffidence and glory.

Together, these conditions lead to a war of all against all; a world where man is wolf to man. Men are equal in the basic sense that "the weakest has strength enough to kill the strongest, either by secret machination or by confederacy with others" (Hobbes, 1904: Chapter xiii). "From this equality of ability arises equality of hope in the attaining of our ends" (Hobbes, 1904: Chapter xiii). All are thus equal and all may have a right to all things equally. Yet scarcity of desirable things prevents each from having as much as he deems his right - this makes enemies out of men.

Enmity is intensified by competition, diffidence and a lust for glory. "The first maketh men invade for gain; the second, for safety; and the third, for reputation" 
(Hobbes, 1904: Chapter xiii). Yet even if no one is seeking confrontation, fear of others and the imperative to react to those fears eventually pushes men towards defensive war, for "there is no way for any man to secure himself so reasonable as anticipation" (Hobbes, 1904: Chapter xiii). Moreover, the desire that every man harbours, "that his companion should value him at the same rate he sets upon himself" (Hobbes, 1904: Chapter xiii), leads to conflict over issues pertaining to reputation and vanity.

The absence of an overarching power to enforce peace is the central factor which unleashes the full horror of such a world. "During the time men live without a common power to keep them all in awe, they are in that condition which is called war; and such a war as is of every man against every man" (Hobbes, 1904: Chapter xiii). In the same sense as that bad weather consists not only of showers, fighting is not a constant symptom of conflict. However, any disagreement or sudden emergence of desire for the augmentation of power may quickly degenerate into violence. In such a world, there is no practice of industry because the fruit thereof is uncertain, "and the life of man [is] solitary, poor, nasty, brutish, and short" (Hobbes, 1904: Chapter xiii).

This conflictual logic can be escaped only when at least one of Hobbes' assumptions either does not hold, or is neutralised by others forces. Decisive inequalities in terms of power typically lead to an imposition of hierarchical order, thereby significantly mitigating conflict and violence. The establishment of an international government could thus serve in ending the state of war by ending anarchy. Even if a world government cannot be established and anarchy thus continues to structure relations of actors, conflict could be drastically reduced by constraining competition, diffidence and glory. Competition and glory serve in encouraging offensive, unnecessary acts, and diffidence leads to excessive fear followed by measures designed to pre-empt actions which have not manifested themselves beforehand (i.e. defensive war - or pre-emptive war) (Donnelly, 2005:32).

Among the forces which could have countervailing effects, Hobbes stresses "the passions that incline men to peace" and reason, which "suggesteth convenient articles of peace upon which men may be drawn to agreement" (Hobbes, 1904: 
Chapter xiii). Yet Hobbes has little confidence in the ability of reason and the fear of death, in the absence of government, to work together in effectively containing conflict.

\subsection{Neorealism and its critics}

Much of the discussion thus far touched upon the failings of neorealism: its inability to account for ideas, and the resulting unilateral focus on material considerations. Let us therefore now look in more detail at neorealism, and how it came to eclipse traditional interpretations of realism in the social sciences and among policy makers (Donnelly, 2005:31). Neorealism, or structural realism, is a theory of international relations introduced by Kenneth Waltz in his 1979 book "Theory of international politics". Neorealism emerged from the North American discipline of political science and reflected a broader trend of reformulating traditional approaches in a positivist guise.

The USA, in the aftermath of the Second World War, steadily rose to a central position in terms of the importance of academic output. America's lead was especially dominant in the natural sciences. Science provided the United States with impressive material production capabilities. As a result, the US acquired unlimited reach in terms of power projection and impact capabilities. It derived its superpower status mainly from the technologies provided to her industry and military by the natural sciences. In the USA, at the time, the confidence in the scientific method was supreme, as was the prestige of the exact natural sciences. Indeed, the American confidence in the power and premise of science and instrumental reason was paramount and uncontested, amounting to the national ideology of the USA (Molloy, 2006:134). Under the influence of such a spirit, which championed the exact - hard sciences, a group of scholars from the University of Chicago pioneered attempts to extract the methods of the natural sciences and make them applicable to their own fields of study, mainly economics at the time (Bourdieu, 1988:774).

The appropriation of the scientific method by the American academic community had a profound effect on the nature of theorising in the social sciences. 
The language of the social sciences was colonised by the language of the philosophy of science, and by the scientific discourse itself.

One consequence was that the structuralist approaches to the social sciences, the so-called positivist approaches, depend on very narrowly defined ontological and epistemological commitments. For instance, many fields transformed themselves based on discourses that spoke of actors as unitary, rational and materially driven by self-interest, in a system which exerts certain structural forces on them. For these structuralist theories, subjective forces are unimportant since it is claimed that all actors are simply rational (and thus ideologies, religion or other belief systems play no role) and that positivist knowledge is universal knowledge available to all (basically the Kantian universalist position; neokantianism) (Wallerstein, 2004).

Structuralist approaches to economic theory proved to be very powerful in producing insightful knowledge about economics as it was perceived to be working in reality, and thus rose quickly to a position of importance around the country. Other social scientists, inspired by this apparent revolution, remodelled their respective fields accordingly. Morton Kaplan pioneered the reformulation of the field of political science in the structuralist mould. He sparked the second great debate of international relations, which would lead Kenneth Waltz, in the field of international relations, to do what others had already done in their fields: to articulate a structuralist interpretation of realism - neorealism (Molloy, 2006:16-20). Neorealists agree with other realists on the centrality of actors seeking survival, rationality and international anarchy. For them, actors are materially self-interested rational calculators sharing a common existence in anarchy. They agree that as long as there is no overarching authority which can neutralise the effects of anarchy, distrust and self-help will remain the dominant characteristics shaping common existence of actors (Waltz, 1979, Mearsheimer, 2014).

In one aspect, neorealism departs significantly from other realisms: the role of human nature. For neorealists, human nature plays a role of marginal importance. They argue that states are the primary actors which they consider to be universally vested with like capabilities and equally rational. Equally rational here is meant in the 
sense that other beliefs do not interfere with the sovereign position attained by rationality in the epistemological perspective upon which neorealism ultimately rests. Moreover, knowledge is taken to be universal in nature, and therefore all can aspire to come to the same ultimate true and absolute conclusions. In doing so, neorealists relegate human nature to a marginal position, almost of no importance. (Weber, 2005:15) (Williams, 2005:47) (Molloy, 2006:26).

The central focus of neorealism lies on anarchy and the effects it exerts on states. States must subordinate themselves to the centrality of the system which structures power relations. Ultimately, the system orders states, and not vice versa. As neorealism has apparently shown itself to be very powerful in yielding insightful knowledge about the workings of world politics as perceived by American policy makers, it is no surprise that it has come to dominate the mainstream of international relations academia. Indeed, many subfields of international relations, such as security studies, are almost entirely monopolised by neorealism (Buzan, 1997).

However, in conforming to the positivist mould of social sciences, neorealism is based on very rigid epistemological and ontological commitments. Neorealism thus is largely unable to converse with non-positivistic approaches to the social sciences, including critical theories and postmodernism. Neorealism privileges a select number of methods of gathering empirical facts about the world - such as economic power statistics, military manpower numbers, or geographic considerations expressed in the language of philosophy of science, as well as other facts which claim to have been derived from the world through supposedly scientific methods - and then processes all of these data (which all centre on particular aspects about the material world out there) in accordance with narrow "if $\mathrm{X}$, then $\mathrm{Y}$ " sequences.

The theory subsequently arrives at a set of conclusions which may or may not correspond with the real power political situation in world politics (Molloy, 2006:34). Neorealism may say something about the status quo in relation to material factors, but, as critics such as Molloy point out, it is unable to contemplate power and change in world politics in more nuanced terms. For instance, neorealism was not able to foresee the downfall of the Soviet Union, nor could the school understand why this 
had happened. Indeed, neorealism is unable to account for subjective power relations, and can only take into consideration material factors in world politics. In the wake of the so-called fourth great debate, scholars employing postmodern and critical approaches to international relations have come to criticise neorealism for its perceived flawed epistemological and ontological commitments (Molloy, 2006:4).

\subsection{Classical realism, postmodernism and epistemological compatibility}

In light of the Fourth Debate, and also reflecting on the inability of neorealism to defend against the arguments put forward by its critics, classical realism is currently undergoing somewhat of a revival (Benneyworth, 2011; Rösch, 2014). Through a rereading of classical realism in the light of postmodern insights, we can come to see aspects of subjective power that were lost during the dominance of neorealism.

Molloy (2006), Williams (2005 and 2007) and Walker (2010), among other critical scholars, see in traditional realism a critique of power politics under conditions of anarchy. In this revival, the role of ideas and beliefs is taken into consideration. Approaches to realism which emphasise the dual importance of human nature and anarchy, mainly classical approaches to realism, tend to be more open in terms of commitments to epistemology and ontology, and thus allow for conversing with other schools of thought. An innovative dialogue is possible between classical realism and schools of thought that rest on a postmodern understanding of epistemology (Williams, 2005:11).

Such is made possible by understanding that classical realisms and postmodernisms all operate with spatiotemporal conditionality of knowledge, as Karl Mannheim called it (Rösch, 2014). This means that knowledge is created in a historical, cultural, and socio-political context. The significance and relevance of any given system of knowledge lies in its social context. As time progresses, beliefs evolve and some assumptions are dropped, while others are acquired. If systems of 
belief fail to adapt to the times, they may fade or become completely supplanted, as was the fate of feudalism in the aftermath of the French revolution (Hampson, 1975).

Different eras of history were thus characterised by particular modes of thought which determined the creation and shaping of knowledge and defined the adopted systems of belief (Rösch, 2014). For classical realists as well as postmodernists, any claim to universal knowledge and absolute objectivity is impossible, and the insistence to the contrary is seen as an act of "epistemological imperialism". Rather, classical realists promote what Morgenthau understood as perspectivist objectivity. Perspectivist objectivity is established by a hermeneutical process by which appearance of reality is analysed through clearly defined concepts. These concepts depend on the forms which reason can provide for them. These forms are in turn derived from beliefs or any other kind of knowledge.

Thus, as times change, beliefs evolve and change, and the image of the object yielded by perspectivist objectivity also changes. Concepts do not serve to distinguish features of an object, but concepts allow for the recognition of features by constructing them (Kant, 1998). Seen from this perspective, classical realists, in agreement with postmodernists, understand that concepts do not have universal and fixed meanings, but are epistemological means through which actors can approach the appearance of reality by categorising and analysing its elements. Meaning thus

depends on concepts which in turn depend upon the specific historical, cultural, and socio-political contexts. As these contexts change, meaning changes. Or rather, appearance is the result of changing knowledge (or beliefs, in more general terms), which in turn is conditioned by power (Molloy, 2006:9). Anarchy, accordingly, exerts an important structural force, yet what that means for social life can ultimately only be established by relations to power considerations linked to the complex workings of human nature.

\subsection{Realism as a form of critique of power in world politics}

Departing from such a background of revival of classical realism, Michael Williams, in "The Realist Tradition and the Limits of International Relations", lays 
out the critical nature which can be found in the tradition of realism, which he calls wilful realism, through three general features (Williams, 2005:5-8):

Firstly, there is a relationship between realism and scepticism. Realists are characterised by a rational approach towards the questioning of reason itself. Realists ponder over the role of knowledge and understand reason as of great importance, while also insisting on the importance of empirical knowledge and historical knowledge. However, realists are often highly critical of modern approaches to empiricism and rationalism as means to gain knowledge about the workings of politics, and are critical in general of modes of knowledge modelled on the ideal premise of the Enlightenment (positivism; empirical realism).

These concerns of the realists are not abstract or anti-scientific, but are grounded in the conviction that knowledge and other belief systems play an imperative role in the construction of order, and in guiding and orienting action. This sceptical approach does not rest on a position which is eventually nihilistic; on the contrary, realists understand that the political order must rest on beliefs common to all subjects, and so to build and secure such beliefs is key in attaining security in any given space shared by subjects. Yet they deny that there is a universal position which can be taken on knowledge. This leads realists to consider the relation between politics and knowledge: the politics of knowledge, and knowledge as a condition of politics.

Secondly, let us turn to realists' understanding of relationality. Realists assume that neither the subject, nor the political order in which it is placed, are fixed or possess universal meaning, belief and content. Realists thus concern themselves with the construction of subjectivity through relational processes working on the levels of subjects and the communities they pertain to. The concern with relationality is grounded in historical and sociological considerations, which aim at examining processes of constitution, maintenance and transformation of politically ordered principles. This concern is thus also conceptual and philosophical. Realists understand that belief and knowledge underlie action, and that conditioning knowledge therefore means conditioning subjects. 
Further, they highlight the inescapability of relationality, by which, for instance, the subject defines its identity in relation to others. The observation is made that concepts gain meaning in relation to their antithesis. Realists thus seek to avoid such relationality devolving into dualism, where understandings of identity or knowledge are defined completely in terms of opposition to what they are not. The world is not black and white, but rather features many shades of grey. This means that, for realism, relationality is not just analytic. It means that relationality is a political and ethical sensibility in which the relationship between self and others attains significance as a political principle.

Thirdly, there is the question of the relationship between realism and power politics. Power is central to any approach towards realism. Realism, as a form of critique, is interested in understanding how multiple forms of power work together in politics. This includes material factors, as well as power considerations in the context of claims of knowledge, forms of subjectivity and structures of formal and informal authority and action. Beyond these issues which are essentially of analytical nature, there also lies, however, a broader set of political and ethical imperatives. According to this vision, politics is identified by its specific duality: an indeterminacy that makes it concurrently a domain of power and unavoidable struggle, as well as a domain of openness and self-determination.

Realism as a critique understands that the recognition of the centrality of power in politics will not result in reducing the occurrence of politics of pure power, nor in reducing the use of violence. Upon reflection of the classical understanding of the role of mitigation and management, realism as a critique thus seeks to advise on a politics of limits which recognises the potentially destructive - as well as constructive - character of power driven politics, and which seeks to reach out to positive possibilities while containing its destructive potential. Indeed, as Williams argues in Realism Reconsidered (Williams, 2007:10), in reflection of a close reading of Morgenthau, realism as a form of critique must consider questions of ethics and what constitutes the good and the worthy. Absent such considerations, and thus taking to extremes, as Peter Pomerantsev argues in the case of modern day Russia, a world emerges in which nothing is true, and everything is possible - the good, the bad; all is 
relative (Pomerantsev, 2015). With these aspects and limitations in mind, let us in the following sections reconsider realism by highlighting and considering subjective aspects of power, or rather, let us try to understand how subjective power works.

\subsection{A critical rereading of the key concepts of anarchy and human nature}

The theatre of struggle which emerges from such a critical rereading of realism is one in which both material and non-material factors play a role. Due to the outstanding influence of neorealism in the field of international relations in recent years, subjective considerations pertaining to power have been almost completely pushed aside. How the theatre of struggle appears, in the light of the arguments made by postmodernists and other critical scholars, can be revealed through a critical rereading of the dual considerations of human nature and anarchy. Following in the trails of Michael Williams (2005; 2007), Thomas Hobbes can be seen as the paradigmatic thinker of wilful realism (Williams, 2005:50).

The recognition that the political and social worlds must be wilfully constructed by human subjects lies at the heart of the Hobbesian political thought. Hobbes does not hold that anarchy leads to perpetual enmity between actors. According to Hobbes, anarchy can be overcome through practices which allow for mediation between actors. These practices are, however, conditioned by limits imposed by both authority and knowledge.

In the light of a critical perspective, Hobbesian state of nature, which is commonly accepted to underlie almost all approaches to realism (Donnelly, 2005:30), is more complex and challenging as a foundation for thinking about international relations than has been the case throughout most of the mainstream of the school. Mainstream approaches generally look at the Hobbesian state of nature in order to understand the logic of anarchy, and then highlight implications for material considerations (Measheimer, 2014). Hobbes, reread through a the critical perspective of wilful realism, describes the state of nature as a complex metaphor illustrating the role of knowledge and belief in political action, as well as the decisiveness of the 
politics of knowledge in political order (Williams, 2005:7). Indeed, through a critical rereading of Hobbes, state of nature goes far beyond mainstream anarchy and rationality, and instead comes to ask questions about the construction of social action and political orders, under conditions of stable and legitimate political authority (Williams, 2005:9).

\subsection{Anarchy reconsidered: the impact of competing beliefs}

Through a close rereading of Thomas Hobbes' Leviathan, we come to understand that the (epistemological) state of nature is designed to illustrate a world in which there is no certainty, no common accepted truth and no consensus. In such a world, where there is a multitude of groups claiming to be in possession of the truth, and where there is no instance which can define (with authority and legitimacy) what is true and what is not, there is conflict (Williams, 2005:20). The symbolic function of the metaphor of the state of nature, for Hobbes, is thus to illustrate the relationship between knowledge, belief and the social construction of order.

Hobbes (1904), by referring to the state of nature, seeks to uncover the ground on which political order is ultimately rested. By reconstructing practices of knowledge, he seeks to find a secure grounding for political authority in a theatre of endemic conflict and struggle. Hobbes employs a cultural and political strategy: an active, wilful attempt to construct political order in a time where the spectre of war and death was seen everywhere. Hobbes does not limit himself to theoretical assumptions and assertions. Rather, he attempts to promote the construction of a selfconscious politics of material power, calculation and interest - the Leviathan - which can create and manage a stable and peaceful political order in which a given instance of truth is relatively stable and accepted by all (Hobbes, 1904).

As a starting point to understanding Hobbes' concerns with international politics, Williams suggests the problem of knowledge - the point from where Hobbes himself departed (Williams, 2005:21). Hobbes lived during a moment of European intellectual history, when questions pertaining to certainty and truth were contemplated with renewed vigour. The 'crise pyrrhonienne', which dominated 
thinking circles during the sixteenth and seventeenth centuries, stood at the outset of a sceptical movement led by thinkers such as the French philosophers Michel de Montaigne and René Descartes (Vogt, 2014).

At the heart of the concern of this sceptical movement lay the claim that sense perception was inadequate as the basis for knowledge. A classic example of how sense perception could mislead was given by the illustration of a pole plugged through a body of water into the ground. The part of the pole placed in the water appears to the eye as bent, and thus does not correspond with what the eye would expect when looking at a pole stuck into the ground on land. Changes of appearance through instruments, such as magnifying lenses, or how perception changes with age, were other examples pondered over by these intellectual precursors to Hume and Kant.

Which appearance and perception could claim the status of truth could thus not be decided by sense perceptions, but rather demanded a set or rational criteria for their evaluation. The questions which consequently followed were what these criteria should be, and were they would come from. If reason alone would decide on the criteria, as some suggested, then the problem of self-referentiality would come to the fore again (Williams, 2005:22). The implications of such an approach would be that reason would have to decide what is true and real based on how reason defines itself.

Reflecting a mode of thought which was sceptical of all certainties, several different approaches to define reason were put forward. Thinkers disagreed on what reason exactly is. Consequently, for reason to be able to function as the judge for deciding on truth, reason would have to first judge all interpretations of reason itself, and come up with a universal perspective which it could employ. Yet doing so would lead again to the self-referential problem: in order to define the one approach to reason which could then be employed to examine all other interpretations of reason (the universal approach which should result of reason looking at reason), is precisely the approach needed at the outset of just such an exercise.

Recognising this problem, Montaigne saw the criterion of judgment at the heart of the sceptical challenge. He pondered over the variety in representations given by 
sense perceptions about the world, and asked thus what standards should be employed to judge what is true:

To judge the appearances that we receive of objects, we would need a judicatory instrument; to verify this instrument, we need a demonstration; to verify the demonstration, an instrument: there we are in a circle [...] Since the senses cannot decide our dispute, being themselves full of uncertainty, it must be reason that does so. No reason can be established without another reason: there we go back to infinity again.

Montaigne quoted in Williams, 2005:22

These problems uncovered by sceptical thinkers were crucial to the thinking of Hobbes. Knowledge about the truth of moral and empirical questions, according to Hobbes' own understanding, is always particular, based on how things appear, and conditioned by individual appetites and aversions. Williams draws on Richard Tuck, who notes that Hobbes' "crucial idea [...] was simply to treat what is perceived by man - the images and so on which are immediately apparent to an internal observer as bearing no relationship of verisimilitude to the external world. Man is effectively a prisoner within the cell of his own mind, and has no idea what in reality lies outside his prison walls." (Tuck quoted in Williams, 2005:22)

Seen from this perspective, anticipating the perspective of the postmodernists, there is no way to look behind appearance - at reality as it supposedly is in itself - as empirical knowledge is always hypothetical and conjectural. By contrast, rational knowledge is like a language. It consists of a set of formal definitions and a set of rules, like grammar, which govern the relations of its parts. Williams, again quoting Tuck, argues that for Hobbes

[..] the actual existence of anything which is the object of our thinking is irrelevant. A language is simply a formal system whose relationship to reality is puzzling and contentious; but it is the only tool we have to reason with. Hobbes consistently used the analogy of counting to explain what he meant by reasoning. Just as effective counting consists in understanding the rules of a formal system (the natural numbers) which may not have any relation to reality, so effective reasoning consists in understanding the meanings of words within the system of language without having any clear belief about what they refer to.

Tuck quoted in Williams, 2005:22

The relation between truth and empirical reality which emerges from this framework is always problematic. Thus for Hobbes, truth is not an absolute and universal status. Rather, truth comes about as the outcome of a set of accepted and logically related frameworks of definitions and referents; truth, for Hobbes, is a 
function of logic and language, not a relation between language and the objects represented in it (Williams, 2005:23).

Very much in line with a postmodern understanding, Hobbes asserts that the manner in which subjects understand the world in which they are placed, and the meaning thereof, is not structured by the world itself, but rather, constructed by subjects themselves. The conditioning by individual appetites and aversions - as Hobbes refers to it - play an important role. If something appears as good or bad to a subject, it is due to the subject's judgment, not because the object is good or bad in itself. In such a world, where appearance and perceptions are not fixed, there is no natural order and no natural harmony between subjects. From this insight follows that the social universe is fundamentally constructed by subjects reproducing the world as they believe it to be. Or as Hobbes put it: "The actions of men proceed from their opinions" (Hobbes quoted in Williams, 2005:23).

In the light of these considerations, realism as a critique proposes an alternative interpretation of Hobbes' state of nature (Williams, 2005:24). The state of nature, seen through this interpretation, is not about a struggle of all against all, where subjects - guided by universal reason and all adhering to the same epistemic perspective - employ material means in a quest for survival. To the contrary, according to this perspective, the state of nature is marked by the absence of agreements on epistemic positions.

In this state of nature, subjects construct their own realities, they entertain their own understandings of what is good and what is bad, what is desirable and what is undesirable, what is threatening and what is unthreatening, and they act on the basis of these beliefs. In Leviathan, Hobbes writes that "whatsoever is the object of any man's appetite or desire that is it which he for his part calleth good; and the object of his hate and aversion, evil; and of his contempt, vile and inconsiderable. For these words of good, evil, and contemptibel are ever used with relation to the person that useth them, there being nothing simply and absolutely so, nor any common rule of good and evil to be taken from the nature of the objects themselves." (Hobbes, 1904) 
In De Cive, Hobbes articulates his views more around the point of what this means for conflict: "Wherever good and evil are measured by the mere diversity of present desires, and hence by a corresponding diversity of yardsticks, those who act in this way will find themselves still in a state of war." (Hobbes quoted in Williams, 2005:24)

Through this close rereading of the Leviathan, sensitive to subjective considerations, we arrive at the conclusion that the lack of agreement on what the world is - and what it ought to be - gives rise to an understanding of an anarchic state of nature. This understanding is far more profound than what is captured by the security dilemma or relative power thinking, advocated by contemporary main stream materialist orientated realist scholars. Let us in the next section consider what such an understanding means for fear. Fear is understood by all realists to be an important factor. For classical realists, fear is linked to human nature and beliefs. Neorealists, while denying the emotional side of fear, nonetheless capture the effects of fear through game theoretical approaches such as the prisoner's dilemma (Donnelly, 2005:37). Yet a postmodern reading of fear is of course much more complex, as we shall see.

\subsection{The mobilising power of fear}

The fear inspired by the Hobbesian state of nature as described - a state of common existence absent a common epistemic outlook - is not reducible to the fear which the mainstream realists of our day see as the consequence of unequal distribution of material factors. Fear resulting from such a reading of Hobbes' state of nature is a fear of the unknown - and unknowable - nature of reality as a whole (Williams, 2005:24). This fear is linked to knowledge: subjects seek to know the causes of things they encounter in their lives in an attempt to master them. Yet the search for knowledge can ironically lead to conflict. The desire to know the final cause of things leads subjects to believe in cause and effect, and thus in the idea that influence can be exercised beyond material limitations. Different lives, conditioned by different kinds of assemblages of systems of beliefs, come to different 
perspectives on what constitutes the truth. In doing so, fundamentally irrational and irreconcilable beliefs can come to structure a subject's mindset in the endeavour of countering fear. The resulting actions thus may come to cause a further deterioration of the situation faced by the subject. Williams draws on Jan Blits in underlining the point:

Fear is a pain, and men naturally avoid pain. Men therefore seek to avoid not only the object of fear, but fear itself. But an objectless fear is an unresolvable fear. No one can fight or flee what he cannot identify or know. To be resolvable, fear must attach to something; it must have an object. Thus when an object is lacking, men will find an imaginary one. They will invent an identifiable object they can fear. 'And therefore when there is nothing to be seen, there is nothing to accuse, either of their good, or evil fortune, but some power, or agent invisible: in which sense perhaps it was, that some of the old poets said, that the gods were at first created by human fear.

Blits quoted in Williams, 2005:24

In such a state of nature, not even fear of death, which Hobbes considers universal, can create a stable order (Donnelly, 2005:34). For even if all subjects would agree on the desirability to prioritise physical self-preservation above all else, there would still be a disagreement on what constitutes threats to subjects, on how to react to these threats, and how to make sure that such threats could not arise in the first place. Thus, the problem lies not in an inherent lack of trust. Rather, in Williams' interpretation, the state of nature is conditioned by epistemological indeterminacy which in turn results in endemic mistrust and conflict (Williams, 2005:25).

The potential for conflict inherent in such a tendency towards irreconcilable beliefs given by unconstrained anarchy is augmented by a further paradoxical property of causal logic. Ideally, logic and fear work together in creating the conditions for peace and stability. Yet, for Hobbes, logic can be a factor conditioning the distrustful and destructive workings of the state of nature. Hobbes argues that the ability of individual subjects to use language and logic to create projections about the future leads them to feel fear when contemplating such a thought. Consequently, subjects devise actions which create the very conditions they seek to avoid. Logic, employed by subjects, allows for causal reasoning of cause and effect through time: "if $\mathrm{X}$ now, then $\mathrm{Y}$ later". Causal reasoning is a process crucial to wellbeing and effective action - indeed, causal reasoning based on logic is a central element of what it means to be human. Yet causal reason also allows for speculations about the future 
to govern actions set in the present. Fears situated in the present can be stimulated by imagination about the future - and it does not matter whether the imagined future is plausible or not.

Fear is thus a central feature of the workings of the state of nature, and subjects in such a state cannot rest, even in times of tranquillity, engaged in familiar activities. For, the abstractness of reasoning makes it always possible to picture some potential life-threatening outcome in any simple situation. And since the fear of death, which is constantly present in the state of nature, takes on an obsessive character for a subject striving for survival, the subject will always strive to anticipate the sudden appearance of danger - even if there is no threat present at all.

For being assured that there be causes of all things that have arrived hitherto, or shall arrive hereafter; it is impossible for a man, who continually endeavoureth to secure himselfe against the evill he fears, and procure the good he desireth, not to be in a perpetuall solicitude of the time to come. So that every man $[\ldots]$ like $[\ldots]$ Prometheus $[\ldots]$ in the care of future time, hath his heart all the day long gnawed on by feare of death, poverty, or other calamity; and has no repose, nor pause of his anxiety, but in sleep.

Hobbes cited in Williams, 2005:26

Departing from this understanding, perception of reality and appropriate actions/reactions are not informed by material factors alone, but also by imagination about the possible future - by images of potential danger and violence therein. These imaginary projections into the future lead to fear felt in the present, and function as the ground of justifications for actions which are not necessary and adequate in the context of the present. Indeed, these actions may in fact be inappropriate, thus leading to a situation of danger and violence, the pre-emption of which was the objective in the first place. Imagined worst case scenarios are thus a constant guide in such a world, and as subjects adhere to them, they create a world of violence and despair - a world that subjects try to avoid, yet end up constructing unintentionally. Moreover, by applying logic to visions of horror and death, subjects devise measures which create the conditions they are so afraid of. The result is an illogical war of all against all. 


\subsection{Human nature reconsidered}

In the light of this revival of classical realism, and as a consequence of the criticism directed at neorealism, realists have reconsidered the role of human nature in conflict (Rösch, 2014). Without denying the central importance of anarchy, these realists also stress the importance of human nature as a conditioning factor of power struggle. Such realists recognise that anarchy plays an important role in driving actors towards conflict, yet that the particular functioning of human nature plays an important role in conditioning the possibility of conflict (Donnelly, 2005).

Actors rationalise the world in which they are placed based on what they know. What they know is only the reflection of their perspective, and the knowledge they cherish may be faulty or overwritten and structured in accordance with a given nonrational world view, such as religion. The actions they devise come in response to the course of history they assume will unfold in accordance with their thinking about the future (Williams, 2005:26). Under the ever-present heavy hand of fear, actors thus often give priority to worst case scenarios. This in turn leads them to act in ways which are not rational as seen by others, and indeed, which may come to inspire fear in them, thus leading to the scenario which was supposed to be pre-empted in the first place: a scenario of conflict and competition. Moreover, such realists, understanding the role of common beliefs which must underlie any minimal social configuration, argue that actors may compete in structuring such common beliefs. Believing in the universal truth and righteousness of a particular belief may drive actors to attack and conquer one another.

For Hobbes, beliefs are an important factor in competition (Williams, 2005:26). Hobbes comes to the conclusion that subjects, vested with language, which enables them to construct and communicate abstract beliefs and ideas, may come into conflict with one another, as particular beliefs become the objects of desire and contestation. In chapter xiii, Hobbes mentions three principal causes for quarrel:

So that in the nature of man we find three principal causes of quarrel. First, competition; secondly, diffidence; thirdly, glory. The first maketh man invade for gain; the second, for safety; and the third, for reputation. The first use violence, to make themselves masters of other men's persons, wives, children, and cattle; the second, to defend them; the third, for trifles, as a word, 
a smile, a different opinion, and any other sign of undervalue, either direct in their persons or by reflection in their kindred, their friends, their nation, their profession, or their name.

Hobbes, 1904: Chapter xiii

Interpreted through the understanding that the state of nature is marked by an absence of a common epistemological outlook, we can come to comprehend that subjects are willing to fight for their beliefs, and indeed - especially in reflection of the third point made by Hobbes - are motivated not by logic and reason alone, but by motivations pertaining to the sphere of feelings and desires more so than to cold calculations.

An insult, for instance, is not a threat an individual subject's physical wellbeing, but rather an attack on that person's honour. Thus, an insult may well provoke a reaction in which the anger created through disrespect and dishonour overrides the deep seated fear of violence and death (Williams, 2005:27).

Such dynamics (Williams, 2005:27) are especially destructive and intense in the context of religion. Religious belief and authority depends upon conviction in a higher being on the part of the subjects. A higher being, such as God, is not merely an idea, but an actual reality - the source of absolute truth. And thus, consequently, the commitment to the values which come together with any given faith, can easily become the determining belief governing all actions. Since these beliefs depend on assumptions which are not necessary rational (that religion is not the domain of rationality was a key insight of Kant and was an important point in explaining the separation of the phenomenal world from the world of the noumenon Kant, (1998: B xxxi), these beliefs are not up for a rational discussion in between subjects, and may also have nothing to do with material considerations. Indeed, as seen through the course of world history, in the Crusades (Madden, 2013), in the Thirty Years War (Wedgwood, 2005), and currently in the MENA region, religious beliefs at times outweigh material considerations and are an important factor conditioning fear, distrust and enmity.

Man may be a pleasure/pain machine, but whether he is vexed by a flung insult or gladdened by the burning down of a rival church depends on his beliefs, not his nerve endings. The opinions that guide and misguide people's lives are not themselves the products of rational pursuit of private advantage. Few opinions are picked up and dropped as strategic rationality decrees. An 
individual does not ordinarily adopt opinions because they promote his self-preservation or material advantage. Beliefs are seldom so rational.

Holmes, Passions and Constraint, quotes in Williams 2005:27

The uniquely mobilising force of language and rhetoric intensifies the relationship between belief and action (Edelman, 2001). Hobbes, throughout his writings, places great importance on terms, names, words and definitions - indeed, he seems to be almost obsessed in delimiting meaning in all contexts - for he understands that subjects react more emotionally to words than to facts. Words, crafted and assembled together into phrases and ideas by master rhetoricians, can be more powerful than appeals to material self-interest. Words can stir up and mobilise subjects by triggering fears, emotions, passions, hopes and other strong feelings. For Hobbes, it was a certainty that rhetoric enabled actors to mobilise subjects - indeed, Hobbes worried about subjects killing each other for beliefs linked to religion, honour, glory or other kinds of non-rational beliefs (Williams, 2005:28).

Indeed, Hobbes was very clear and direct on the role of beliefs in human nature. In one of his most famous passages on how forces are marshalled in an effort of defence: "there is no way for any man to secure himself so reasonable as anticipation; that is, by force, or wiles, to master the persons of all men he can so long till he see no other power great enough to endanger him: and this is no more than his own conservation requireth, and is generally allowed." (Hobbes, 1904, Chapter xiii). The means of "force" in this passage is often highlighted by realists who focus on material considerations. However, the word "wiles" implies something quite different. It is an old English word, and implies manipulation, trickery and charm; in the context of Hobbes, actors thus may also mobilise subjective power to attain their ends.

While Hobbes' state of nature and the resulting anarchy enjoy a status akin to universality in terms of outstanding importance among realists, his views on human nature must compete in terms of importance with other classical authors (Donnelly, 2005:33). Other classical realists have uncovered alternative powerful insights into the workings of human nature which feed into the current debate. Let us have a very brief look at some other classical realists, and how they see the workings of subjective power considerations. Since this is not the place to reread each and every 
classical realist through the lens of postmodernism, we nonetheless have a look at some considerations in order to inspire us when thinking about subjective power.

Morgenthau (1973), for instance, argues that "the social world [is] but a projection of human nature onto the collective plane" and "When we speak of power, we mean man's control over the minds and actions of other men. By political power we refer to the mutual relations of control among the holders of public authority and between the latter and the people at large." Morgenthau argues that power struggles do not play out exclusively with material means, but also through ideas, beliefs and other systems of knowledge - a theatre of conflict ultimately situated in human nature. Morgenthau currently enjoys a rejuvenation, as many scholars rediscover his insights into the complex relationship between subjective and objective power. (Williams, 2005 and 2007)

Long before Morgenthau and Hobbes, Niccolo Machiavelli (1999), writing at the turn of the $15^{\text {th }}$ century, entertained complex ideas on the relationship between appearance and reality. In reflection of his understanding of human nature as written in the Prince: "A prince should present the appearance of being a compassionate, trustworthy, kind, guileless, and pious ruler. Of course, actually possessing all these virtues is neither possible nor desirable. But so long as a prince appears to act virtuously, most men will believe in his virtue. If the populace believes the prince to be virtuous, it will be easier for him to maintain his state. Moreover, men will judge their prince solely on appearance and results. Thus, it doesn't matter to the people that a prince may occasionally employ evil to achieve his goal. So long as a prince appears virtuous and is successful in running the state, he will be regarded as virtuous." (Machiavelli, 1999:75) And "Everyone sees what you appear to be, few experience what you really are" (Machiavelli, 1999:76). Machiavelli thus recognises that power is not a universally measurable force, but rather subjective in that other actors may misjudge power levels - an actor can thus be viewed as more powerful than he really is, thereby deterring others from assault and aggression.

Another example is given by Carl von Clausewitz. Discarding the positivist approach of his contemporary rival Antoine-Henri Jomini to the study of war as 
unilaterally focused on material consideration and on mathematics and calculation as a means of producing meaningful insight in war, Clausewitz championed the importance of morale, by which he meant a belief in the outcome of a given war (Strachan, 2007). Only when soldiers and armies believe in victory, do they engage in the deadly work of war with the vigour and conviction which eventually can secure victory. "The ardour of his spirit must rekindle the flame of purpose in all others; his inward fire must revive their hope. Only to the extent that he can do this will he retain his hold on his men and keep control. Once that hold is lost, once his own courage can no longer revive the courage of his men, the mass will drag him down to the brutish world where danger is shirked and shame is unknown." (Clausewitz, 1984) 


\title{
5. The epistemological Leviathan and the imperative of common beliefs
}

\begin{abstract}
A close rereading of the Hobbesian state of nature in the light of postmodernism allows us to understand that a space, in which there is no epistemological consensus and therefore no commonly accepted truth, nor shared beliefs, nor agreement on what constitutes a threat and how to guarantee peace and tranquillity, ultimately leads to a tendency towards conflict. Subjects are unable to agree on what is good and what is bad, on what is a threat and what is not. The epistemological state of nature thus leads to fear, mistrust and overreaction, followed by violence and conflict (Williams, 2005).
\end{abstract}

Reason, by logical inference, must therefore conclude that any given society which aspires to peace, stability and harmony must stand on a minimal consensus in terms of epistemological perspectives. Or rather, where humans want to live in peace and harmony, they must do so by sharing common beliefs, for if they want to eliminate fear of death from their immediate lives, they cannot continue to cherish beliefs particular to each subject alone. At the very least, they must entertain agreement on aspects critical to the establishment of peace and stability. In other words, they may disagree on a minimal matter such as the taste of a certain dish, but they must agree on what is a threat and what is not.

Of course, as with the traditional interpretation of the state of nature, the epistemological state of nature does not exist. Let us leave the image of the state of nature, which - as Hobbes points out - has been a reality since the times before civilisation, many thousands of years ago. Instead, let us look at contemporary times, where we can see that there are a multitudes of spaces which are governed by common beliefs (Hobbes, 1904: Chapter xiii). On the most basic of assumptions, we can claim that each group of people constitutes a form of society, and that there is a link between society and culture, for each society must rest on at least one culture, and in turn, each culture must be reproduced through society. 
Culture, then, could be understood as a belief system: knowledge seen from a particular perspective (Tylor, 1974:1). In other words, although it is possible to imagine that each and every subject existing in this world adheres to a particular constellation of beliefs, in reality it makes more sense to think of groups of people, for, in any given social configuration - and there are many in this world - there are dominant perspectives which exert a pull effect on subjects within their reach (Durkheim, 2008). Those who do not adhere to the common perspective are punished by all others - or rather, those who do not adhere are not able to interact meaningfully with all others. Hence, these individuals are quickly forced to change their ways, should they want to buy something, or participate in an activity with other people: if one stands alone, one is unable to interact with society.

As Nietzsche has pointed out in his work on perspectivism, in any social configuration, certain perspectives become dominant through a struggle by which one party, favouring one set of beliefs, prevails against all others by exercising a will to power (Molloy, 2006:6). Postmodernists and other critical thinkers have developed several modes for conceptualising how common beliefs may emerge and function in society and/or are enforced.

The importance of a common belief, a concern which arises by considering the implications of Nietzsche's perspectivistm and those of Williams' (2005) inquiry, is a common concern for postmodernists and critical theorists (Rosenau, 1992:77). Accordingly, and corresponding with the spirit of postmodernism, there are many models, each of which may observe something about how common beliefs work, and how they shape subjects within their reach.

One approach to the necessity of common beliefs is provided by French philosopher and sociologist Pierre Bourdieu. Bourdieu uses the term doxa, which he borrows from classical Greek. In Gorgias, Plato paints the Sophists - professional rhetoricians who taught people how to speak in exchange for money - as wordsmiths who employ the malleable doxa of the common people to their advantage without shame. Doxa was thus used by Plato to denote a common belief, or popular opinion. For Bourdieu, doxa denotes knowledge (or belief) which is granted within any 
particular social configuration. Doxa for Bourdieu thus is the knowledge that is taken for granted within any social configuration. Hence, doxa encompasses the set of ideas, norms, beliefs and other types of knowledge that are generally accepted as axiomatic within a given social situation (Pouliot and Mérand, 2013:30).

Another approach is given by the Italian Marxist thinker Antonio Gramsci, and his concept of common sense. For Gramsci, Common Sense is the set of incoherent, spontaneous beliefs and assumptions embedded in the conformist mode of thinking of the popular masses in any given social configuration. Common sense is in part the outcome of good sense as derived from live experience, in part superstition, folklore, simple religious beliefs and the deposits of previous philosophy, and in part consists of interests and attitudes of the ruling elites. Indeed, the latter part is of key importance, as Gramsci stresses that common sense is established by a process of consent to the ruling class' perspectives which are thereby accepted by society at large as being in its own general interests. Common sense thus functions by providing its adherents with a set of norms, knowledge and beliefs (Jones, 2006:9-10).

A third approach towards understanding how a particular set of beliefs and knowledge is established as the truth, and thus as the perspective a given society should adhere to, is given by Michel Foucault's regime of truth. The regime of truth denotes any given society's general politics of truths. The regime of truth distinguishes the types of discourse which are accepted and true from those which are unacceptable and false. The types of discourse to which Foucault refers he interprets as entities of sequences, of signs, in that they are enouncements: statements in conversation. Through the regime of truth, that which is true is separated from that which is false. Those discourses which are classified as true are encouraged and reproduced, while those discourses which are classified as untrue are suppressed and denied. Thus similar to doxa or common sense, the regime of truth informs subjects on a common perspective on truth, beliefs, norms and other forms of knowledge (Mills, 2003:74.) 


\subsection{Governmentality and the enforcement of a common beliefs}

Postmodernists disagree to what extent the establishment of a common epistemological outlook is the result of agency in an organised, intentional process. Bourdieu's doxa appears to be the product of common interaction, and not the conscious creation of an actor (although Bourdieu says that actors can aspire to intentionally change the doxa). Gramsci's common sense is in part structured by the ruling elites, but not in a coordinated act. Rather, it is the result of class interests and attitudes. Foucault, in turn, stresses that intentionality has no place in his conceptual framework.

International relations scholar Michell Dean (2010), by drawing on the writings of Foucault and in particular his idea of governmentality, has provided a conceptual approach which may serve in illustrating how states and international organisations promote certain beliefs by conditioning and shaping subjects within their reach accordingly. This process corresponds with the Hobbesian premise of an epistemological leviathan - a power centre which privileges one perspective of truth, and enforces it throughout its reach.

Space is an important consideration in this relation, for governmentality inside the territory of a state works quite differently to outside of it, in anarchy. Inside a territory, the state - in the sense of the epistemological leviathan - is in a position which attains her some natural advantages in relation to all others who may aspire to interfere with the underlying common beliefs. Outside of the territory of the state, this is not necessarily the case.

Michel Foucault, in a number of historical studies, explored how power shapes subjects in accordance with a set of desired beliefs and knowledge. In Punishment and Discipline (1995), Foucault traces the historical development of the penitentiary system in the west. Through Genealogy, an intellectual method which he learned from Nietzsche, Foucault argues that, as time passed, states invested ever more effort in conditioning and shaping the conduct of prisoners in accordance with certain beliefs and knowledge. Minds were targeted, as were bodies. As time passed, ever more refined methods were deployed. 
From these many detailed writings of Foucault, Mitchell Dean has extract the concept of governmentality. In "Governmentality: Power and Rule in Modern Society (2010)" Dean attempts to conceptualise how power, working through the state, shapes subjects in accordance to desired sets of beliefs, norms and other forms of knowledge. The power deployed can be seen as subjective power, in that it eventually targets the beliefs which come to underpin the subjects within reach. In broad terms, governmentality denotes the art of government whereby, through calculated and targeted actions, states govern populations by creating subjects that serve desired ends.

Acting through so-called governing technologies, which are constituted by agencies, institutions and other agents pertaining to the state, and by employing tailored strategies and tactics, governments aim to shape subjects according to need and corresponding with specific knowledge. In doing so, governments can count on the relative consent of the governed, by appealing to their desires, aspirations, interests, beliefs, fears and hopes. The outcome is that desired - yet shifting - ends are enabled, while the consequences and effects may never be controlled in the full. This in turn demands constant adjustments in aims and changes in strategies on the part of the governors (Dean, 2010).

The art of government rests on a distinct rationality which informs all questions pertaining to the how, the why, the who and the what. Informed by such a grand narrative - for instance raison d'état, or liberalism - governments may aspire to structure their actions and understand the desired ends accordingly ${ }^{20}$. The art of governmentality, in a very crude and embryonic condition, first emerged during the renaissance and was then refined over the subsequent decades and centuries. The main rationality upon which governmentality was built in this early phase was that of raison d'état. According to its premise, states would do all so as to secure and increase power relative to other states, to increase efficiency of its exporting

\footnotetext{
${ }^{20}$ However, it should be clear that each state will fine-tune the programmes in accordance with more specific sets of beliefs - For instance, French interpretations of liberalism are different than US interpretations of liberalism.
} 
enterprises, and to shape populations in such as way as to conform to the interests of absolutist monarchy (Dean, 2010).

In effect this meant that the state remained relatively absent from the lives of most subjects. Instead, the Church took on the task to ceaselessly reaffirm the grand narrative of the divine rights of kings. The state itself focused on soldiers, clerks, diplomats and others who were indispensable for the workings of the state, by conditioning them in such as manner as to ensure that they perceived and understood the world in accordance with the will of the state. As Foucault argues in Discipline and Punishment (1995), other subjects who happened to be engaged with institutions under the control of the state or her representatives, such as prisons, incipient public educational systems and institutions geared towards health issues, also came to be conditioned in accordance to knowledge privileged by the state.

During the 17th and 18th century, the Enlightenment and its grand narrative of reason progressively came to challenge the grand narrative of the divine rights of kings, and the notion of raison d'état. With the fall of the French monarchy at the closing of the 18th century, the Enlightenment came to constitute the guiding rationality of governments all over Europe (Hobsbawm, 1996). The rationale of liberalism stressed the notion that populations must constitute the main object of government action, while the economy may constitute the primary source of power if managed according to its own natural law-like necessitates. Indeed, liberalism understood that populations and economies rest on quasi natural laws, and that governments thus must manage the needs and imperatives of both of these complexes, while also leaving them with a high degree of liberty so as to function properly (Dean, 2010). States approaching this in the correct manner would enjoy never before seen dimensions of power, while those states that did not follow these insights would eventually fall behind in terms of power and influence.

Indeed, governments in Western Europe took action in the wake of the Napoleonic wars, which played an important role in making sure that the grand narrative of the Enlightenment prevailed against the many absolutist rulers. Eventually all took the lead of the French revolutionary and imperial government, by 
enacting their own approaches to governmentality informed by the rationale of liberalism, and subsequently surged in terms of power and capabilities (Hobsbawm, 1996). As a result, the 19th century was the moment in the history of mankind when Europe conquered all, and remade all in her image. This was possible through the never before seen capabilities available to these governments, which allowed them to easily conquer the whole of the world (Kennedy, 1989).

According to Dean, governmentality saw its birth and development during the renaissance in the form of governmental population management, which developed slowly and in parallel to other forms of governmental power, mainly sovereign power and the power to discipline subjects of interest. In the early moments of the history of the state, sovereignty was the dominant form of power, while governmentality played a subordinate role through the relatively autonomous processes pertaining to the management of populations as performed by local and regional administrative bodies, as well as by allied institutions such as churches and religious orders. Born in the renaissance and then proliferated with vigour all over Europe in the aftermath of the peace of Westphalia in 1648, sovereignty vested state rulers with a powerful tool with which to pursue their interests, both inside and outside of their respective territories (Knutsen, 1998).

Yet while rulers did what they thought necessary in the pursuit of state survival and glory, populations often played a minor role in the overall calculations of the top policy making elites. Populations, though, nevertheless had to be managed. This was done through governmental management undertaken largely by administrators on local and regional levels, and by the Church and other religious orders. These processes were not the daily concerns of princes. The wellbeing and management of the larger population thus took place mainly outside of the view of top government officials, which saw sovereign powers as the domain of their concern (Dean, 2010).

Discipline, as a form of power, was devised in the 17 th century. It then developed ever more sophisticated techniques with the aim of instilling certain codes of behaviour in targets groups of subjects, such as soldiers, sailors and others imperative to the workings of the state, so as to augment state power in the domestic 
and international settings. The aforementioned soldiers came to constitute the professional military components, which - together with the diplomatic corps, often recruited from the aristocracy - came to form the security apparatus used by states to secure their independence from others, as well as to intervene by the force of the sword in domestic concerns where necessary (Dean, 2010).

However, once raison d'état had been supplanted by liberalism as the guiding rationality of governance, populations and the economy turned into the principle objects of interest for governments, while sovereignty and discipline were absorbed into the broader logic of governmentality. States used sovereignty and discipline in combination with governmental management in a general attempt to further the interests of the state in the domestic and international context. All three thus became united in the endeavour to shape and condition subjects within reach in accordance with a select set of beliefs, norms and other forms of knowledge.

At the core of the liberal informed art of government stood the insight that both populations and economies worked according to quasi natural laws, and that the state therefore must preserve and protect both, while also creating subjects which conduct themselves accordingly. In more direct terms, this meant that the state must create subjects able to operate in the market, to know how to enjoy and deal with liberty, to handle the concept of free opinions and to accept that some may have more in material terms, while others live in poverty. Indeed, this last point in turn keeps subjects aware that they must act accordingly to the imperatives of the market, or fall into poverty themselves, leading subjects to self-govern and self-reform ceaselessly (Dean, 2010). Subjects thus were conditioned to understand the world as it appears, from a perspective privileged by the government.

There are several path towards the shaping of subjects: Firstly, the state can attempt to mould and shape morals and ethics frameworks underlying a society. As subjects generally want to frame their actions in harmony with what is generally accepted as morally integral and ethically correct, they will turn to what Dean terms "self-government" (Dean, 2010). Or rather, subjects always strive to avoid to be seen as immoral and unethical, and thus will conduct themselves in such manners as to 
make sure that they remain within what is considered good and right. Secondly, and more directly, the state can employ bureaucracies, agencies, and other institutions under its direct or indirect control in order to issue regimes of practices which see to the shaping of subjects. For instance, an education regime may see schools enacting a curriculum which stresses the teaching of skills and explanatory frameworks as desired by the government and the market - since the market is understood to be of imperative importance for governments. Thirdly, the state may aspire to structure available options to subjects in such a way that they have no choice but to conduct themselves as desired. This can happen by designing the spaces in which subjects live their lives, by defining the laws according to which subjects have to live, by structuring market mechanisms in such a way that subjects are confronted with a predefined set of choices, or by other means which nudge the subject into a desired direction.

Dean stresses that the techniques, technologies and regimes of practices, are always in a state of flux, and change throughout time and space. Indeed, the governors always have to find new ways of establishing techniques and mechanisms by which they can shape subjects in accordance to desired results (Dean, 2010). For instance, when TV and Radio first emerged, they were relatively firmly controlled by governments. As private actors began to send their own programmes, governments could still make sure that their ends were met by shaping ethical norms governing journalism.

Governmental practices, the desired kind of subjects, as well as the broader aims which governments aspire to achieve, are all informed by knowledge which is constantly renewed and rearticulated. Under the dominance of liberalism, knowledge of the positivist guise came to enjoy a status of privilege. As ever new positivist knowledge is articulated, programs are enacted which make sure that the governors are constantly retrained, practices are constantly reformed and desired subjects are constantly remoulded. Or rather, as knowledge changes, everything else changes. What is thus true at one moment may become false at another moment, hence the overall discursive framework in which the governors and the governed find themselves is subject to constant change and reform. Reigning rationality and form of 
knowledge production may implicate and constitute each other mutually. As one changes, the other may also change (Dean, 2010).

For instance, liberalism, as the guiding rationality, has itself been changed and mutated as history took its course. At its inception, classical liberalism produced knowledge according to which the market should be completely deregulated, subject to laissez faire practices. As time went by, new knowledge led to economic liberalism and social liberalism whereby it was understood that the subject should enjoy some protection of market forces, such as assistance in times of illness, the possibility to obtain schooling for children, etc. During welfare liberalism, the social net was even further expanded, and thus the governing subjects were retrained to understand that people need large-scale protection and security. In contrast, after the inception of neoliberalism, subjects were moulded to understand that states are limited in what they can do, and that everyone must therefore take up a degree of own responsibility (Dean, 2010).

Moreover, when we look at the states which make up the so-called West, we see that they are all somewhat different in terms of what they value or what they encourage. Reflecting on such differences brings us back to the idea that there is no universal perspective, but rather only particular perspectives. As such, in the end, grand narratives do not inform the governmentality apparatus, nor does positivist knowledge. Rather, certain particular beliefs prevail over other particular beliefs, thereby establishing themselves as apparently true and valid to a critical number of subjects within the spatiotemporal configuration of relevance to the governmentality apparatus in question. In other words, the way subjects are conditioned is the outcome of dominant beliefs cherished by those in charge of the governmentality apparatus. To change the beliefs cherished by these key subjects, leads to a changing of the way subjects are conditioned.

\subsection{Global governmentality}

While inside a state, governmentality rests with the state and government. In the space of the global, there is no world government and no world state. The result is 
anarchy, and thus each actor is driven to defend his own views, and indeed remembering the causes of quarrel mentioned by Hobbes - is eager to impose his views on others. According to Hobbes, in a state of anarchy, everyone is her own judge in deciding what is proper to herself. In the UN Charter, one of the key principles maintains that states are defined sovereignties, vested with the right to selfdetermination, and the right to non-intervention. However, as Hobson and Sharman (2005:63-64) argue, the Westphalian international system has always known power hierarchies. Whereas all states are equal in terms of rights, they are very unequal in terms of power. The English School of International Relations, recognising such, has argued that only great powers can aspire to broker their own destinies. They are the ones who negotiate with each other on the terms according to which social reality is constructed (Bull, 1982).

The result is that the space of the global is ordered by an international institutional framework resting on the will of great power interaction. The international institutional framework has important implications for each and every state. Through membership, where globally binding international treaties and norms are established, and through participating in international trade, all states around the world are subject to influences which are not of their own making. Michell Dean's conceptualisation of governmentality has recently been adapted to the global context (Larner and Walter, 2004).

Governmentality came about with the unleashing of the Enlightenment, and thus was employed first by post-absolutist regimes in Europe and the United States. As such, the targeted shaping of subjects during the 19th century was mostly confined to the domestic setting pertaining to the states of Western Europe and the United States. However, some states which commanded large empires, such as the United Kingdom and France, also attempted to shape the subjects in their colonies, yet with different aims compared to the efforts deployed in the domestic setting (Said, 1979). However, after the First World War, when the legitimacy of colonial holdings was increasingly questioned, the imperial powers argued that the populations in their colonies are not ready for self-determination, and that it was the obligation of the colonial motherlands to continue to guide the overseas populations towards progress 
and welfare (Keene, 2002). After the Second World War, this argument became untenable, and soon after, especially during the 1960s, European imperial powers retreated from the global stage, releasing most of their colonies into freedom. However, if there was ever a moment when the right to self-determination was real and privileged over any other consideration, this moment was swiftly cut short through new approaches of global governmentality. The Cold War, globalisation and the claim of universality of human rights would serve as justification for powerful states to continue to aim to shape subjects not pertaining to their own populations (Woods, 1999).

Governmentality, working in one form or another through the space of the global, came to be exercised in a number of forms, targeting foreign populations and foreign states alike. This can happen unilaterally and multilaterally, directly and indirectly. A direct, unilateral approach to global governmentality is given when one state seeks to shape foreign subjects within its reach, as for instance happens when operating networks of institutions, such as schools, in foreign lands. International media operations can also be seen as such an approach.

For instance, Russia has in recent years invested heavily in the English language TV channel Russia Today (RT). Through RT, Russia can disseminate its narrative directly into the homes of Europeans and Americans, and others around the world, and thereby undermine the regimes of truth as enacted in these countries. In the direct approach, foreign subjects are target directly, thereby bypassing legitimate institutions within the theatre of action.

An indirect approach to governmentality takes place when one state seeks to shape other states so that the agencies, institutions and other actors pertaining to the targeted state come to operate in such a manner that they shape their own populations in accordance to the ideals and desires of the initiator state. The instruments which can facilitate such an indirect shaping are many, and may include treaties, threats, coercion as well as the assimilation of the elites of the targeted state into the perception of the dominating state (Dean, 2010; Hindess, 2004). 
Multilateral global governmentality takes place when one set of powerful states with common interests structures formal or informal international regimes which then directly and indirectly shape foreign populations and foreign states alike. Formal institutions are organisations such as the UN or the EU, and they engage members and non-members, states and populations. The most powerful informal regime is identified by Dean as the market.

Markets are powerful in that they exert clear demands, such as specific legislation, or labour power specialised in particular areas, and so forth. If the demands of the markets are ignored by given states, they find themselves poor and isolated, deprived of power and influence. What is so powerful about the markets is that there is seemingly no one in charge, and thus those making demands of noncompliant states can always say that nature provides the rules, and that there is nothing they can do about that. In reality, we know that a few powerful actors define the basic fundamental mechanisms according to which the market functions. In other words, the way the market works today is the result of a few powerful actors defining how it should work (Gill, 2002).

Whatever the approach, the effect is always the same in that populations which find themselves in foreign lands are shaped according to the desires and wishes emanated from powerful states dominant in the international system. These states are thus in a position to condition the international institutional framework in accordance with their perspectives (Tucker, 1979). When the art of government rested on the premise of raison d'état, states would look mainly inwards and shape domestic subjects according to domestic concerns, whereas only few subjects were incorporated into the military and the diplomatic corps so as to pursue her international interests (Dean, 2010).

In the aftermath of the Napoleonic wars, however, when raison d'état was replaced by liberalism, dominant states began to be interested in shaping populations all over the world. The states capable of operating in the space of the global, and thus capable of imposing themselves on the many locals bound thereto, began to develop an interest in promoting progress, modernism, market principles, the rule of law and 
property rights. Where they exerted direct control, such as in the colonies of the West, they set up technologies with the aim of shaping subjects directly. Where they did not exert direct control, such as in Latin America, they drew up treaties which obliged the states in question to set up governmental technologies of their own so as to shape their own populations according the wishes of the powerful (Hobsbawm, 1996).

When in the aftermath of the First- and Second World Wars the European empires crumbled, and when coercion and imposition became imbued by a strong sense of illegitimacy, indirect and multilateral means of shaping subjects around the world gained salience. On the forefront of the direct multilateral means were organisations pertaining to the UN system. Set up and controlled by the West, and often recalibrated by the use of brute realism (Tucker, 1977), these organisations came to rest on liberal inspired rationalism in orienting their actions towards those in need. As time went on, they adapted discourses to include notions of the imperative of development, the inevitability of globalisation, the need for resilience and the imperative of good governance. As such, these international organisations, such as those pertaining to the United Nations, demanded from those states which relied on outside help that they set up technologies which would see their own populations shaped in the mould of Western citizens (Hindess, 2004).

Indirect multilateral governmentality, on the other hand, is constantly present through the imperatives of the market. Cold and merciless, markets demand of states that they shape their populations in accordance with the needs of capital, trade, commerce, industry and production in general. Such a thing, however, can only come to the detriment of traditionalism and local cultures, as the market claims that the qualities it procures are universal in nature, and non-negotiable. Thus states that refuse to adhere to these demands, and shape their subjects accordingly, risk to remain outside of the fold, to become isolated, poor, and eventually deprived of power and influence. Those states, on the other hand, that give in, and that set up the technologies necessary so as to shape their subjects in harmony with the outside demands, risk a loss in identity, a rise of inequalities and a loss of control over certain affairs (Hindess, 2004). 


\subsection{Intentionality}

Governmentality, as conceptualised by Dean (2010), thus serves to illustrate how groups of subjects can be conditioned in accordance with desired beliefs. However, the question remains open as to whether this happens intentionally: whether actors interested in promoting particular beliefs can configure the governmentality process in such a manner that subjects within their reach are conditioned in accordance with the intentions of the engaging actors. Alternatively, the enforcing of common beliefs may happen autonomously from the wishes and aspirations of the engaging (political) actors, in the sense that the epistemological leviathan reproduces beliefs that are already dominant and existent among the many subjects who eventually act in the capacities as agents for the leviathan. Foucault himself argued that intentionality has no place in his thinking about the relation of power and knowledge (Mills, 2003:49). Hence, following Foucault, there is no room for strategising, manoeuvring, negotiating, or planning, as the engaging actors can never hope to reach what they intend.

Intentionality and strategy, however, lie at the heart of realist thought (Strachan, 2007). Following the realist argument, any given participant in competition and conflict intends at a minimum to secure her own survival (Donnelly, 2005). Moreover, following the Hobbesian analysis of the causes of quarrel, the intention to see particular beliefs prevail against others is another cause for conflict (Hobbes, 1904). Williams (2005), in his close reading of the realist tradition, thus argues that wilful realism must consciously consider the role of beliefs in constructing the conditions which can eventually provide security and peace for all. Seen from an abstract position, it might be possible to imagine that the leviathan does not care about the nature of beliefs, as long as it is unitary and adhered to by all subjects within its reach. In practice, however, a choice in favour of one set of beliefs, and to the detriment of others, is unavoidable. Yet on the other hand, we know that there is a link between policy makers who aspire to intentionally implement programmes, which in turn are rested on the beliefs which are ultimately produced by social scientists (Kenkel, 
2005:37-41). Or rather, social scientists provide ideas which are then picked up by policy makers and introduced into the state apparatus.

Intentionality, as a conceptual approach, allows for some leeway in thinking about strategy, and thus intentionality can be found in Bruno Latour's ActorNetwork-Theory (ANT). It is not intended to enter into yet another theory. Yet it is beneficial to extract some ideas of Latour in order to demonstrate how actors can aspire to intentionality when targeting beliefs cherished by other actors. Latour (2005) argues that in any given social world, there are no unitary actors, which function autonomously and independently from other actors in the same social world. Rather, actors form formal and informal networks by which they co-condition each other. For instance, the process of government is complex, consists of many sub-processes, and rarely involves a single truly all-dominant actor. Even Stalin, Mao and Hitler depended on vast numbers of supporters and allies. For instance, when Mao found himself progressively isolated among the top ranks of communist party officials in the run-up to the Cultural Revolution, he left the capital and went to the countryside, hoping to rally the support of the masses. He succeeded, and only thus was able to continue to dominate the strategic agenda of the state (Spence, 1999).

Hence, the state consists of a multitude of actors. Some actors which work for the state do so in the capacity of an official position. Other actors are not directly bound to the state, yet are still involved in daily official business. Lobbyists, expert consultants, interest groups, think tanks and many others find themselves in daily intercourse with the affairs of the state (Nownes, 2006). Through permanent interaction on part of numerous particular actors bound by common endeavour and related to each other in a co-constituting relationship, they come to give rise to what Latour calls actor-networks (Latour, 2005:136).

The resulting actor-networks may always change in scope and nature, and besides comprising changing constellations of actors, also incorporate beliefs, as well as material factors commanded by their members. In analogy to a theatre performance, Latour argues that the actors on-stage are only a small part of the whole (Latour, 2005:46). Although the actors are the ones seen in the visible performance, a 
multitude of actions are undertaken by others behind the scenes in order to allow the performance to take place. There are producers, script writers, directors, administrative personnel, makeup artists and so forth. The action of any one actor in the network thus may condition the position and options of all others. Agency, as a result, does not lie with single actors, but with the actor-network as a whole.

Actors in any actor-network may take up two different types of roles in relation to the ideational underpinning: mediators or intermediaries. Intermediaries channel information flows without transforming or distorting them. In other words, by knowing the input provided to an actor, it is possible to determine the output produced in response. Mediators, on the other hand, may transform and modify information as presented to them: once processed, the output may be wholly different from the input. Mediators thus constantly engage the beliefs on which the network rests, at times reinforcing certain aspects, at other times questioning and potentially changing them (Latour, 2005:57).

Actors, by stating aims which seek change in status quo politics, and by employing their multiple techniques, tactics and strategies, may thus aspire to act as mediators in the actor-networks of which they are part. In networks formed with policy elites and with institutions situated inside or outside of the state, actors - with the intention of configuring the governmenatlity process - can aspire to occupy the role of mediators. Hence, they constantly seek to influence and shape discourses of relevance to the governmentality process (Kenkel, 2005:42-44), thereby conditioning the so-called actants. Actants, as defined by Latour (2005:54), constitute the motivational factors on which the actor-networks rest their actions.

As a result, the strategic leeway with which actors - with the intention of affecting the governmentality process - may operate is ample, and the possibilities for arriving at a desired goal are manifold. By engaging the discursive processes which enable the formation and transformation of dominant beliefs, and which in turn inform the governmentality process, actors with the intention of determining the governmentality process can work through strategic means in achieving their ends. 
In reference to strategy, it is worth remembering that strategy denotes the idea of a high level plan, which, in moments of uncertainty, and by taking into consideration countering forces, promises the attainment of ends (intentions) by the artful deployment of the available means. However, as Clausewitz has pointed out, the moment a strategy is implemented by an actor, countering forces may rearrange themselves in reaction, and thus may neutralise the strategy, in the hopes of achieving the intended aims of the countering actor. Thus, whereas an actor may hope to achieve his intentions by drawing on strategy, he may never be assured that things work out as envisioned.

\section{The mobilising power of images and language}

Language, as concluded by Williams through his close reading of Thomas Hobbes' Leviathan, can function as a powerful mobilising force, by allowing subjects to think about the future (Williams, 2005). At one moment or another, any subject is eventually confronted with the unexpected - with new ideas in general. The mind's ability to imagine ${ }^{21}$ consequences leads the subject to construct images, which may show a future different to the hitherto expected life trajectory - and indeed, depending on circumstances, this imagined future is one dominated by fear. The implications then are that the subject is induced to think about countermeasures, which elicits a change in attitude and action if deemed necessary. Contemplation, especially when infused by fear, may come to induce irrational behaviour on the part of the subjects. In the worst case, this epistemic outlook results in breaking of the status quo state of common tranquillity and peace, as subjects are not only ready to defend their beliefs, but also, driven by a lust for glory and power, to further their own beliefs to the detriment of others. Furthermore, by suggesting a course for action

${ }^{21}$ We remember Kant's words, "I can think whatever I like, as long as I do not contradict myself, i.e., as long as my concept is a possible thought, even if I cannot give any assurance whether or not there is a corresponding object somewhere within the sum total of all possibilities" (Kant, 1998:B xxvi) 
so as to avoid worst case scenarios, actors, who target subjects with a constructed narrative of their own making, can aspire to have subjects and groups of subjects doing and acting as they wish.

In chapter four we have argued that actors engage in the art of conditioning subjects, for else there is conflict. The implication of the above argument in relation to this is that there is no definitive conditioning of subjects. Even when a subject has been conditioned for all of its life in accordance with a certain perspective which it has come to accept wholeheartedly as universal, it is nonetheless possible to challenge the beliefs that this subject cherishes about the world, through the mobilising power of languages and images.

American sociologist Murray Edelman (Edelman, 1971 and 2001), studying the mobilising power of languages and the role of beliefs, suggests that fear and hope function as the two main mobilising factors for actors in the history of politics. Historically, upheavals, acts of mass violence and mass expenditure of resources are linked to exaggerated fears and hopes experienced by groups of subjects (Edelman, 1971:1). Language and other systems of signs function as the means by which subjects can be reached and mobilised. By evoking fear and hope, subjects can be made to leave the path of reason, which is supposed to guide them in their daily intercourse with reality, and push them towards engaging in what can be seen by others as irrational activities.

According to the common assumption of positivist sciences, the human being employs reason as the means of interaction with the social universe in which it is placed - irrational conduct is understood to be the exception, the result of mistakes. Edelman, however, argues that the contrary is the norm, that irrationality is so common, that rationality on the part of individual and groups of subjects constitutes the exception (Edelman, 2001:1). Edelman stresses that irrationality may not be intended, yet that the process of cognition is so complex, that misconceptions and false beliefs, rather than sound concepts and sound knowledge, usually come to structure the subjects' thoughts, and thus lead subjects into acting and thinking irrationally. 
Edelman argues that false consciousness plays its role in this process. False consciousness is a Marxist concept which has been developed by French Marxist Louis Althusser (Edelman, 2001:65). False consciousness claims that subjects do not construct a meaning-giving framework by critically considering their particular circumstances and best interests, but rather by cherishing beliefs which are alien to them, and which actually correspond to the perspective of the elites in any given society. False consciousness can thus be understood in terms of ideology. Moreover, whereas false consciousness is chiefly structured by the interests of the elites, it does not affect only the masses, but also the elites, who are subjects themselves.

Yet even if there were no ideologies, and subjects could perform cognition in accordance with the Kantian ideal - i.e. by strictly using reason, and guided by intuition - they would still come to act irrationally, since they depend on knowledge they believe to be true, yet never know to be true, and thus on concepts which are not of their own making. Hence, this leads them to construct an appearance of reality which is distorted and flawed. The production and reproduction of beliefs and (mis)conceptions is an ongoing and never ending process (Edelman, 2001:4-5). The subject is born into a certain configuration, and then is constantly shaped and reshaped according to dominant beliefs (Dean, 2010).

Subjects are usually unable to see the whole picture, and thus rely on fragments of the whole in making decisions. This allows those with intentions of pushing their own agenda to structure available information in such a way, that subjects who draw on this information may come to false conclusions: conclusions which the structuring power wants them to arrive at (Edelman, 2001:74-76). Commercial advertisement is arguably an explicit attempt of structuring information in an incomplete or misrepresentative manner with the intention of promoting particular perspectives on the advertised products. Companies construct the appearance of their products in a favourable light in order to increase sales. In politics, similarly, policy approaches are linked with bombastic images about the future they will bring about, in order to marshal support. Advocates of particular social or economic policies link their ideas to inspiring leaders, such as Roosevelt, Cato the Elder or Charlemagne, who they claim would have approved of their proposals, or who they claim served as 
inspirational models (Edelman, 1971:77). In a similar vein, the policy approaches of their adversaries they link with Stalin or Mao or other leaders who are not remembered favourably by those with common sense.

Whole groups are (mis)conceptualised by drawing on superficial traits commonly attributed to them, in order to rationalise their supposed natures (Edelman, 2001:87-88). The Chinese are supposedly collectivist in nature, the Germans are supposedly punctual, the Americans supposedly pragmatic, the Brazilians supposedly happy and the Russians supposedly have hearts of ice; the poor are supposedly lazy, the rich are supposedly virtuous and artists supposedly like to enjoy liberty for which they pay the cost of enduring poverty. The mistaken beliefs derived in this manner work in rationalising disparities and inequalities. Subjects come to think it is normal that the poor are poor and the rich are rich. Groups, moreover, gain cohesion by cognising others as groups that are not from the same spatial and socioeconomic background, using generalisations which seem to explain why they are the way they are.

As Edelman argues, groups - and even individuals - benefit in certain contexts from creating misconceptions, misbeliefs and simplified assumptions about other groups, and are thus provided with a rational incentive for creating, disseminating and perpetuating such false beliefs (Edelman, 2001:3). The assemblage of fragments of the big picture consists of images which are generally accepted as true by those depicted and by other interested parties, and also of images which are constructed to serve power interested purposes. The beliefs which thus underlie the conduct of politics and rhetoric are always somewhat mythical in nature.

For instance, the economy, or the political system, or the international system, are all extremely complex phenomena, difficult to understand in their entireties even for specialists who dedicate themselves to their study. For common subjects to be able to grasp and discuss these phenomena, it is thus necessary to adopt simplifying models, for instance in the form of metaphors. This process of simplification and reduction leads to the elevation of misconception and false representation into the 
status of dogma, while crucial aspects of social and economic reality are omitted and neglected (Edelman, 2001:4).

Misconception about causal relations, and about the phenomena behind appearance, encourages misplaced and flawed action which fails to address the underlying problems, and thus perpetuates the status quo (Edelman, 2001:67). A concise understanding and knowledge of how policy comes about, and how influence is wielded in matters related to government and social interactions, is foreign to most people. As a result, beliefs about the spectacle of politics are derived from crude preconceptions and from biased media reporting which focus on personalities, aspects they arbitrarily decide to be important and sensationalist reporting, while ignoring the more complex political, social and economic relations underlying the social universe.

There is a diverse range of opinions on all matters. Some believe that climate change is manmade. Virtually all believe that people in high public office and in the cadres of big corporations exert a high level of influence and authority (Edelman, 2001:10). There is, however, great disagreement on which agencies, institutions and non-state actors are potent in terms of effective power, and which of these play a positive role in the reproduction of social reality. Subjects are thus conditioned by power relations they cannot grasp, nor understand (Dean, 2010).

The widespread construction of misconceptions is also catalysed by the production of reality as conducted by the mind of the subject: Every object of cognition takes strikingly different forms and different meanings conditioned by the time observed, the mood governing the moment, the perspective adopted, and the interests in play (Edelman, 2001:103). Yet nonetheless, subjects commonly assume that reality is continuous and unfolding according to a stable pattern, and that its essence is experienced similarly or identically by other subjects. Edelman thus argues that this suggests that particular subjects go about their lives assuming most of the time that their interpretations about the world and the objects therein are shared by others.

For politics, this dynamism means that there is much more dogmatism and selfconfidence than is justified. In experiencing we encounter many discrete moments 
rather than one continuous reality, we look for snapshots which we claim capture something about the real reality, and which we then present as such to others (Edelman, 2001:10). When a particular momentary snapshot serves our interests we tend to frame reality in the terms of it. A law and order politician, for instance, is inclined to see crime as the result of dangerous and vile subjects, rather than the result of economic conditions which may drive subjects into crime. A general, who fought many battles, is inclined to stress the battles he has won as the result of his virtues, and those he has lost, as the mean-spirited interference of Fortuna.

Edelman concludes that the production of reality, as experienced by the subject, thus depends not on being, but on knowledge - a view very much in line with postmodern approaches to epistemology (Edelman, 2001). Knowledge, or belief in general, in this view, is always permeated by misconceptions which are constructed in a process which sees competing groups incentivised to see their eventually flawed perspectives taken up as hegemonic.

As the subject employs reason in integrating representations of reality into a flawed body of knowledge - flawed in the sense that it consists of misperceptions and concepts which are actually misrepresentations of given considerations in the social universe - the appearance of reality that comes about, as well as the images of the possible future that are provoked, do not necessarily correspond with what a critical inquiry would come to conclude. Rather, the appearance of reality is distorted: reshaped and manipulated. Thus, following this view, it is always possible for wilful actors, working through language, by consciously constructing misrepresentations, to mobilise subjects for a desired cause. Moreover, the subjects in question do not understand what is happening, for they take for true and valid the misrepresentations upon which they rely in cognising the world (Edelman, 1971, 2001).

\subsection{Language and images}

In the construction of misconceptions, language - and the images it gives rise to - play a paramount role (Edelman, 2001:11, 78). It is rare for a subject to observe first-hand all the details of an event or process. Rather, particular observations are 
captured in memorable images, narrated by journalistic accounts, exchanged in daily conversation, delivered in political oratory and used by other sources which strive to present their perspective in terms of striking images aimed at gripping an audience. Metaphors, myth, common sense, stereotypes and science are all sources from which memorable images can be forged. Observations are irrelevant to ideas and thoughts, since observations need to be framed in forms which knowledge provides - thus observations can only be framed by that which the subject believes in, which in turn is not the autonomous product of the subject.

Further impeding the ability of the subject in shaping appearance by autonomous thought are the stereotypical terms in which images are defined (Edelman, 2001:12): good/bad, present/absent, active/passive, global/local, true/untrue, friend/enemy, and so forth. Such binary orderings lead inevitably to simplifications of the true nature of the phenomena these images claim to describe. They ignore the complexities inherent in any given event, situation and continuum, and thus allow for the cognition of appearance in simple, non-critical terms.

Images shape thought - especially political thought - in a decisive way. Yet many words that are heard or read do not give rise to images, they do not affect the subject: certain images dominate thought and so a large number of potential other images are overwritten and never given a chance to influence and structure ideas and actions. (Edelman, 2001:13)

The notion of quantifying and defining images in fixed terms is impossible, since they are created constantly and abundantly. Each word, term, phrase and sentence creates a plurality of images which are conditioned by the audience and the situation which defines the context. Moreover, every image creates further images. The imagination of the originators of images and that of their audiences is bound to augment the already present ambiguity of images, since the functioning of imagination varies with circumstances and because it is impossible to fix definition in space and time with any precision (Edelman, 2001:14). The image of the valiant soldier saluting the flag of the nation is powerful, but not exact: the image tells little or nothing about particular soldiers, or how they conduct themselves in the field. 
Images, rather than critical engagements, thus underlie thinking about the world, and are the basis for interacting with other subjects in common spheres. Edelman argues that from one point of view, images are instance of ritualistic language. They arise automatically from the world as the subjects looks at it, for they reflect what the subject expects, what the subject itself places into appearance. Images usually do not spring from careful observations, considered critical thinking or the interplay of pure reason and logic. Images thus ignore many forms of differences, nuances, subtleties, linkages and connotations. The image of a hero, a scholar, an athlete, an enemy or a terrorist takes little or no account of such people's inner conflicts, misjudgements, network of interests, diversions and personal relationships, while focusing instead on the mental stereotype that the term evokes. (Edelman, 2001:12)

The images that influence action and thought are stereotyped and potent because they flow from powerful established economic and political relations (Edelman, 2001:39-40). Images are decisive in determining the political strength or weakness of the groups they appear to represent. Stereotyped images, for instance, of smart consultants, efficient executives, cunning politicians, lazy social welfare recipients, dangerous foreigners and so on are the bedrock upon which power in society is constructed. The images which are dominant and potent are the ones backed by powerful groups.

Through ever expanding means of mass communication, reaching ever greater proportions of national and global populations, there are deliberate efforts by powerful political actors to construct particular images which serve intentional ends (Edelman, 2001:81). Governments try to spread the belief that they are working in the interests of all. Businesses attempt to disseminate the view that they should be able to operate unhindered by rules and norms, so as to grow and create jobs more efficiently. Environmental organisations, such as Green Peace, engage in endeavours to further the belief that consuming certain goods is bad for the planet and therefore unsustainable. Images are circulated constantly in the media and often these images are the creation of public relations and communications specialists, rather than the outcome of journalists aiming to uncover the complex relations which underpin society. 
Established images, which are relatively fixed in the common understanding of affairs, thus work to preserve and reinforce existing power relations; while novel images, once introduced and having achieved a certain position of prominence, may come to upset the status quo, and can even become revolutionary (Edelman, 2001:1215). In times of security and tranquillity, when subjects feel secure and safe, actors who aspire to change the status quo may entertain limited hope that they can achieve so by mobilising subjects through targeted, constructed images. In times of crisis, however, they can hope for a relevant audience that is susceptible to images of fear and prospect. By constructing specific misconceptions about given issues, subjects can be made to act in ways they otherwise would not have contemplated. For instance, Marxist and anarchist revolutionaries had been spreading their messages in Russia from the last third of the 19th century onwards, yet were never seriously able to challenge the status quo. However, when Russia was collapsing in the face of the advancing German imperial army, the climate of crisis in the main cities allowed Lenin and Trotsky and other Marxist revolutionary leaders to mobilise parts of the population to fight for their cause (Trotzky, 2006).

Moments of crisis are thus moments when subjects are especially susceptible to images and language striving to inspire hopes and fears. A crisis, in this sense, is defined by moments in which things could go either way. For instance, Clausewitz was concerned with subjective factors of heroic leadership and morale of the troops. In his times, battles usually began relatively controlled, as troops positioned themselves and exchanged the first volleys of fire. As both sides find themselves ever more engaged with each other, the moment of crisis arrives. During the moment of crisis, both contenders can hope for victory, everything is open. Accordingly, hope for victory and fear of death reside in both sides. Inspirational leaders like Napoleon would in these moments be able to rally their troops by appealing to the hope for victory, whereas the sight of a leader killed in front of his own men will lead to an increased fear of death among his men (Strachan, 2007).

To sum up, subjects can at any moment be provoked into performing a desired action through the mobilising power of language and images. In our daily lives, we are constantly sought out by dramatic voices and imagery. When we watch the news, 
we see dramatic pictures which urge us to take action. In times of tranquillity, we are less reachable by such appeals. But in times of crisis, when our lives are immediately at stake, or as a consequence of an impending event, we are more susceptible to the mobilising force of power language and images.

Language and images are thus important components of subjective power. In chapter four it was argued that subjective power is applied over the course of time, through governmentality technologies whereby subjects are conditioned steadily over longer periods of time. However, the mobilising force of language and images, as treated in this chapter, denotes the ability of subjective power to get to immediate results by challenging the status quo beliefs held a priori, by evoking images in the minds of subjects which speak of fear or hope, and which thus make the subjects act in ways in which they would otherwise not have acted. In other words, even the most thoroughly conditioned subjects will act in ways not foreseen by their conditioners, if other actors are able to evoke plausible alternative images in targeted subjects about the possible future. 


\section{The method of Pierre Bourdieu}

As argued in the introduction of this dissertation, realists, or policy experts in general, are not interested in the nature of subjective considerations in themselves, disconnected from their implications to world politics. And although we have throughout this text touched (implicitly and explicitly) on how subjective power and material power come together, the focus has remained on the relation between subjective power and beliefs (or ideas): How does subjective power come to interfere with ideas? The social theory of Pierre Bourdieu method offers an approach which makes it possible to imagine how subjective and objective considerations are fused. Moreover, Bourdieu offers a set of thinking tools which allow for the application of his theory onto the social world. By applying Bourdieu's thinking tools on two historical cases, we aim to reflect on the workings of subjective power in world politics. Bourdieu has already been quoted when thinking about subjective power. What follows here is a more in-depth overview of his core concepts and thinking tools (his method) which allow for the application of theory to our historical cases.

The late French sociologist Pierre Bourdieu elaborated a distinct approach towards theory which seeks to bring together material and subjective factors. At the outset, Bourdieu rejects the prevailing antinomies persistent in mainstream Cartesian inspired modes of knowledge, such as structure/agent, objective/subjective, material/symbolic, theory/practice. Bourdieu's approach is based on a non-Cartesian social ontology, proposing a genetic structuralism which is capable of combining a constructivist approach with a materialist approach (Bourdieu and Wacquant, 1992: $5)$.

According to Bourdieu, the task of the social sciences is ultimately "to uncover the most profoundly buried structures of the various social worlds which constitute the social universe, as well as the mechanisms which tend to ensure their reproduction or their transformation." (Bourdieu and Wacquant, 1992:7) The structures which Bourdieu sees at work, conditioning the social universe of which he speaks, in a sense lead a "double life", existing in "objectivity of the first order", as well as "objectivity of the second order". The structure of "objectivity of the first 
order" is comprised of the distribution of material factors, as well as capital, the latter of which Bourdieu interprets as the means of appropriation of socially scarce goods and values (Bourdieu differentiates between four types of capital: social, economic, cultural and political). The structure of the "objectivity of the second order" is given by "systems of classification, the mental and bodily schemata that function as symbolic templates for practical activities - conduct, thoughts, feelings, and judgements - of social agents." (Bourdieu and Wacquant, 1992: 7) At the risk of oversimplifying, we can think of the "objectivity of the first order" as comparable to what neorealism focuses on: the material structure. The "objectivity of the second order" corresponds with the Kantian inspired postmodernist constructivist epistemology: the world is what the subject believes it to be. Subjective power works through the "objectivity of the second order", in that ideas and beliefs are targeted and transformed.

The "objectivity of the first order" treats society in the manner of - what Bourdieu calls - "social physics": an objective structure which can be grasped, measured and mapped out independently of the subjects which live in it. The strength of this objectivist perspective is in its ability to undermine the "illusion of transparency of the social world" (Bourdieu and Wacquant, 1992:8). By discarding perceptions informed by common sense, this perspective allows for the uncovering of determinate relations within which subjects necessarily enter in the production of their social existences.

The "objectivity of the second order" asserts that social reality is "a contingent ongoing accomplishment" of competent social actors who continuously reproduce their social world through the organised and artful practices of daily existence. Subjects produce the world as they belief it is in itself. Beliefs, in an a priori situation, subjects draw on beliefs to guide their actions (Bourdieu and Wacquant, 1992). This perspective shows social reality as the outcome of decisions, actions, and conscious cognitions of subjects to whom the world is given as immediate, meaningful and familiar. The strength of this perspective is that it allows for recognising the role of beliefs in the production of reality: subjects reproduce the reality which they think it is itself. It is in the second order reality where subjective power is deployed. 
However, Bourdieu argues against any one-sided approach and asserts that both structures must be weaved together so as to give rise to what he calls "social facts" considerations which may be material or not, and which subjects are confronted with in their common existence in the social world. Through constant interaction, subjects give meaning and sense to social facts. Bourdieu thus proposes a type of double reading that takes into account the epistemic virtues of both, resulting in a "system of relations of power and relations of meaning between groups". This is in opposition to binary relations, which look at the one or the other. For instance, neorealism looks at the objective while discarding the subjective. Conversely, orthodox postmodernist approaches claim that material factors do not matter at all. Bourdieu's emphasis lies on relations: relations are what gives rise to reality, not the one dimensional considerations of either objective or subjective modes of knowledge production alone (Bourdieu and Wacquant, 1992:15).

A second foundational claim of Bourdieu concerns the perceptual and evaluative schemata which subjects employ in attaining meaning and sense about the world. Bourdieu argues that there must be a correspondence between the social structures as given in society and the mental structures in individual minds. The hierarchical divisions of groups and collectives within society (at state level, as well as within the international society), ultimately implicitly and explicitly expressed in the form of domination and submission, must be rationalised through concepts which normalise and make sense of the status quo (Bourdieu and Wacquant, 1992).

These concepts - which serve as categories of understanding - and the corresponding mental schemata, are thus constituted in correspondence with the social divisions prevalent in reality as it appears to cognising subjects. This means that cognising subjects must draw on concept and forms which correspond with material imperatives as given in the social universe when producing reality. In other words, Bourdieu agrees with Kant that the object must conform to the subject. However, the terms in which the subject can be articulated are constrained by the object. 
The categories of understanding, and the concepts derived from them, are political grounds of struggle. They are more than explanatory frameworks which may lend meaning to what is happening, as they are also instruments of domination. As they are, however, never fixed (although there is a tendency to reify them), Bourdieu argues that it is possible to change reality and the corresponding material structure by changing these meaning giving categories within the realm of the symbolic (Bourdieu and Wacquant, 1992:14). Indeed, Bourdieu argues that those in positions of dominance will always strive to structure the categories of understanding in such a way as to perpetuate the status quo. In doing so, they use subjective power within the limits set by material constraints. Conversely, when material conditions suddenly change, and the categories of understanding are not adapted correspondingly, the divergence between what subjects think they see, and what they think they are supposed to see, can cause crisis, discontent, revolt and even revolution.

This double hypothesis (the double structure, and concepts and categories which subjects draw upon in making sense of the social world in which they find themselves) finds application in Bourdieu's methodological key concepts of the habitus, the field and the doxa (Pouliot and Mérand:24-44). The field is a space in which actors are located according to their social positions. The specific position of each actor in the field comes about as a result of interaction between the "rules of the game" of the field (the doxa), the actor's habitus and the subject's capital. Fields vary in terms of shape, in terms of the rules (doxa) on which they are grounded, as well as in terms of gravitas (some are very strong and attract many subjects, others are barely existent). Fields may never exist in isolation as they constantly interact with each other. Fields are moreover hierarchical as some are subordinate to others. Indeed, most are subordinate to the larger fields of power relations.

A field comes about when a number of subjects enters into a struggle for a given specific stake. In doing so, they tacitly or explicitly acknowledge that the field exists, and thereby give rise to it. A field fundamentally consists of a "set of objective, historical relations between positions anchored in certain forms of power (or capital)" (Bourdieu and Wacquant, 1992:16). To put it in more explicit terms: an academic discipline can be a field; family and friends can constitute fields; a state can be a field; 
the global scene can be a field; the Cold War can be a field. In every field a certain form of capital regulates power relations. For instance, in the field of art, the capital sought after by actors is artistic prestige, whereas in the field of banking, the capital sought after is money. In the field of politics, the capital is expressed in terms of power. The actors competing in any given field are ordered in a hierarchical fashion in accordance to the capital they possess. Those on top will tend to invest in a strategy of preserving the status quo, while those on the bottom will tend to work towards enacting changes with the hope that in doing so their position will improve. At the core of such considerations lies the doxa. The doxa is the intersubjective agreed upon set of rules, according to which actors engage each other; or rather, the common beliefs. The doxa, however, is never fixed, nor is the shape of the field, and both can be contested by the actors engaging in it (Bourdieu and Wacquant, 1992:18).

Habitus, on the other hand, on the side of the subject, is what structures subjects' perspectives - the conditions underlying the capacity for perception of the world, the structuring assemblage that eventually gives rise to personality and worldview. The habitus underlies and structures the compound of actors' dispositions, values and expectations when dealing with the social universe (i.e. when set in a field). However, rather than being completely individualist and unique in makeup, any given habitus exists in conjunction with individual spatiotemporal experiences which are shaped by more general attributes associated with the social group to which the actor belongs. I.e. a person of a given national or religious background will share outlooks with others pertaining to the same group (Bigo, 2011: 238-246).

Put in more practical terms, the habitus can be conceptualised as the structure of the mind and related psychological considerations, such as emotions. It is characterised by a set of acquired schemata, dispositions sensibilities, and tastes. An imperative role in this structuring process is given to the beliefs cherished by the subject. The particular composition of any given habitus is the complex outcome of lived social structures - such as the gender, nationality, and class - as well as personal experiences and life trajectories. It is also of course the result of conditioning efforts on the part of actors in a position to influence the subjects in question. As such, every habitus may be different, while also similar to the habitus of others part of the same 
group. This gives rise to broad shared tastes, preferences, and actions of actors set in the social universe. The concept of the habitus thus destabilises the premise of rational choice theory according to which every actor, no matter what their origin, belief, identity or cultural orientation, will act in a given way when confronted with a given situation. According to the concept of habitus, rationality - or rather, rational action in the sense of attaining the "best outcome" - may differ from actor to actor depending on the factors that combine in shaping the individual habitus (Bourdieu and Wacquant, 1992; Bigo, 2011).

Habitus and field together form a dialectical relationship. Each eventually conditions the other (Pouliot and Mérand, 2013:29). In conjunction, the field and habitus vest actors with what Bourdieu calls a practical sense. A practical sense informs the actions of actors. It is different from rationality, in that possible actor moves are rested on individual outlooks as well as a "feel for the game" given by the subconscious (or conscious) understanding of the doxa. This leads to a quasi-intuitive mode of action. Actors may strategise; overall, however, most of their actions come about through a feel for the game as a result of relations and the meaning giving properties inherent in the doxa (Bourdieu, 1998:76-77).

In sum, Bourdieu's social theory reveals a social universe that brings together subjective and objective considerations, and in which struggle is omnipresent and always imminent. However, this is not only the case in terms of acquisition of capital pertaining to a given field, or in pursuit of the stake pertaining thereto. It is also the case in terms of defining the shape of fields, the doxa (rules) underlying fields, the structuring factors underlying the composition of individual and general modes of habitus, as well as the categories and concepts which explain and rationalise the world as it appears to subjects (Bourdieu and Wacquant, 1992; Bigo, 2011). In relation to the present work, the method of Bourdieu is interesting, for it allows one to think about world politics where material factors and subjective power play a role. At the risk of oversimplifying, we may contrast how neorealism and realism, sensitive to subjective power, appear through the lens of the Bourdieuan method: Neorealism identifies the space of the international as the field. The actors are said to be the states. Capital is expressed in terms of material power. The United States is on 
top of the hierarchy, whereas a country such as Malawi or Lichtenstein is at the bottom. The habitus of the United States, as an actor, is relatively transparent, as culture, identity, religion and other beliefs play no role. Reason thus comes to inform the actions of the United States relatively unhindered. Competition for relative power consideration takes place within the field of the international whereby the doxa is simply given by the imperatives of anarchy.

For realism, the overall play looks similar, in that actors compete for power in the field of the international. However, in doing so, the habitus of other actors, as well as the doxa governing the rules of engagement in any field of interest, are theatres in which subjective power is deployed, and through which the whole game attains a more complex and dynamic character. For instance, during the Cold War, the US, through the Helsinki accords, was able to introduce the factor of human rights into the doxa. Henceforth, the dynamic of the great power competition was changed. Moreover, it could be argued that the Soviet Union was weakened when the West was able to interfere with the habitus of Soviet subjects: In Eastern Europe, subjects became westernised, wore jeans, and wanted to listen to rock music. In Central Asia, Soviet subjects came to adhere to radical interpretations of Islam, and thus renounced the universalist premise of the New Soviet Man.

In the two chapters which follow, we apply our insights about subjective power onto two historical cases. The first case focuses on the French revolution and the rise of Napoleon as the commander of the most formidable power Europe had ever seen. The second case looks at the Soviet invasion of Afghanistan. Following a writing approach inspired ultimately inspired by Aristotle, each case will be narrated in three acts: The first act will provide the reader with the broader context of the case in question, the background story, when the protagonists successfully challenge the status quo, and then rise to power themselves. The second act will focus on how the respective protagonists handle power once in office. The third act considers the outcome, how the protagonists are able to confront their enemies in the context of world politics. Each act is then narrated in terms of what happened, and how power considerations came into play. After each case an analysis is provided of how subjective power decided the outcome. 
By applying the method of Bourdieu, in each case the field in which the respective act take place will be defined, followed by the main actors and how their habitus can be understood and considered. Each act concentrates on limited aspects, thereby opening up the risk for oversimplification and overt generalisation. Yet since this is not the place for a concise and comprehensive account of the historical cases in question, but rather merely an attempt to illustrate how the issues at the heart of this project reflect on history, this risk is considered to be acceptable. 


\section{Historical case one: The French Revolution and the rise of Napoleon}

Let us start with a few words on the Enlightenment. Much of this dissertation is built on intellectual products which came eventually as the result of the Enlightenment. As such, a more thorough exposing is justified here, before we move on to the French Revolution and the rise of Napoleon.

During the Enlightenment, women and men of letters, individuals such as Voltaire, Diderot, Locke, Rousseau, Montesquieu, Hume, Adam Smith, Newton, Bacon and others, challenged ever more vigorously the feudal order which defined the social universe in they lived (McPhee, 2012:10-13). The feudal order was based on the divine rights of kings (McPhee, 2012:85). The feudal order established a hereditary cast system, where the few - the clergy and the nobility - were vested with privileges allowing them to legitimately dominate the rest of society, the common people. Inspired by earlier generations of thinkers, including Bacon, Descartes, Locke and Spinoza, 18th-century Enlightenment thinkers set out to contest and challenge the grand narrative of feudalism. Denouncing the order or feudalism, they offered an alternative, a world in which the values of ideals of liberty, equality, progress, reason, tolerance and fraternity would reign supreme (Dupre, 2004:1-12).

None of these thinkers would live long enough to see a world built upon the cause they advocated: a social universe rested on reason, a world in which reason would enjoy a dominant position unconstrained by traditional authority. They lived their lives as subjects of the old feudal order they contested. Some of them became famous during their lifetimes. Kant, Rousseau and Voltaire were all well known when they were still alive. They were often treated simultaneously with awe and distain; threatened and banished by one prince, and then lodged and praised by another. The struggle they conducted relied on the pen and was fought on the battlefield of the mind. Being in control of soldiers and whole armies, the ruling aristocratic elite felt safe, and looked with a certain sense of bemusement on what was going on in the world of thought and ideas. Indeed, many aristocrats and members of the clergy 
participated in some form or another in the ongoing philosophical debates (Hampson, 1963:14). They educated themselves in philosophical matters, and cherished their own opinions which were not always simply reflective of their class status. They hosted the spaces in which the debates could take place - both abstract and real. Abstract in the sense that they controlled the political conditions which allowed for practices geared towards reproducing ideas in written form, and then transporting these through space from one location to another. Real, in the sense that many salons in which women and men of intellect came together for long hours of discussion and debate were often owned and made available by aristocrats.

Some of the privileged sympathised with the new world the Enlightenment thinkers envisioned, others even went so as far to join them, thereby renouncing the legitimacy of their privileges (McPhee, 2012:216). Most of the aristocrats who knew what was going on considered it merely a game among intellectuals - a small, controllable group, completely disconnected from the great masses of people of Europe. Most, aristocrats and philosophers, probably never thought that their world could change at all - after all, it had been the way it was for more than a 1000 years. The Carolingians, under Charlemagne, had instituted the feudal order in an attempt to put to rest the chaotic times of the dark ages, when a number of barbarian tribes roamed Western Europe in search for destiny, fighting each other regularly (Keegan, 1993).

Yet that was a long time ago, and the barbarian warrior tribes, which Charlemagne sought to settle, had meanwhile turned into separate empires, kingdoms, duchies and other political bodies linked to specific territorial configurations in Europe. In other words, there were no barbarians left: civilization had triumphed, order had overcome disorder. Whereas the past world of chaos and disorder called for the warrior, the world of order and civilization in which the Enlightenment thinkers lived favoured women and men of money and letters over simple brutes with swords in hand.

Thus, as the $18^{\text {th }}$ century unfolded, the discourse of the Enlightenment reached an ever wider public, and the discourse of feudalism found itself slowly but steadily 
challenged and destabilised (Hampson, 1963:185). As the Enlightenment premises were taken up by ever more people, the Enlightenment discourse established itself securely, and then went on to aim for a position of hegemony. The divine right of kings as the rationale which explains the social universe, and thus ultimately God, was deposed by and replaced by reason. The manner in which subjects came to understand the world changed; the production mode of appearance of reality in the minds of subjects changed. Things now made sense not because god created them, but because of universal and necessary laws inherent in nature; laws made and governed by reason (Hicks, 2004:6-12). By employing reason, the champions of the Enlightenment argued, mankind could uncover all the laws which govern social reality. In the realm of science, and linked fields, like engineering, manufacturing and construction, the new mode of engagement had already yielded stunning successes. The age of industrialism and scientific revolution surged ahead.

As this process unfolded, slowly, but steadily, the ground upon which the once absolute power of aristocracy safely stood was opening up. As people stopped believing in the narrative of the divine rights of kings, the legitimacy of the status quo order was called into question. The narratives resulting from the feudal explanatory frameworks were weakened in plausibility, and eventually discarded as superstitious. Eventually, the legitimacy of the whole of feudal Europe was being eroded (Hobsbawm, 1996). The foundation of a whole social universe was called into question. However, the stakeholders of the old order had no intention of simply abdicating their positions on the stage of history. Even though the discourse on which their legitimacy rested was weakened, they still were in control of the state apparatus, and could still mobilise decisive military power. Violence was introduced in the hitherto relative tranquillity of social life. At first by little doses, and then as the balance of power in the in the subjective field of power shifted, violence was applied in ever greater quantities. The Battlefield of the mind was supplemented by real life soldiers, armed with rifles and bayonets (Hampson, 1975).

Whereas the governing elites, feeling secure, had earlier allowed for the peaceful debate of these new ideas, and often joined in themselves; they now turned to suppression. Selectively, peaceful participants of Enlightenment debates were 
targeted with the intention of silencing them. Censors set out with the intention of controlling the written word. Examples had to be made of those responsible for the undermining of the common sense rationale of the divine right of kings. Some of those intellectuals who would go too far publically were fought with the legal system. Of course, the justice system judging them did so under the guidance of the rationale of the divine right of kings, and thus those bringing forth reason in their defence often ended up finding themselves condemned by a system which did not acknowledge the insights which reason claimed to have into the workings of the social universe. Others, who did not conform to the thinking patterns as delimited by the feudal order, more crudely, were stalked, threatened, beaten up, taken away, or simply murdered (Hampson, 1975). The once relatively agreeable climate, in which the contest of competing metanarratives had played out, was supplemented with fear, anger and violence. The sword now joined the pen in an epic battle for what the ultimate principle for the production of reality should be - God or reason.

By the end of the $18^{\text {th }}$ century, the moment of crisis had arrived. The forces of tradition employed the sword in fighting the word, yet they could not undo all the ideas which the Enlightenment had given rise to. Too many people had been in contact with the alternative perspective on social reality, and indeed, the Enlightenment had already influenced the workings of politics and societies in ever wider circles (Hampson, 1975). As more and more people began to adhere to the discourse of reason, thereby abandoning the discourse of the divine right of kings, the emergence of a new world was not to be stopped anymore. Hence, when the middle classes of America and France rose up against the English and French crowns, they looked to the ideas of the Enlightenment when contemplating the post feudal societies they were about to construct.

In France, the revolution started when the King called the Estates General, an ancient feudal institution, which was supposed to represent all of France (Hampson, 1975). He was forced to do so after severe financial and economic problems took hold of the Kingdom of France. As the meeting started, women and men dedicated to the ideas of the Enlightenment seized the opportunity and set events in motion which would eventually result in the French revolution. The case which follows starts with 
the storming of the Bastille, and ends with the Battle of Jena and Auerstaet, where Napoleon smashed a Prussian army twice the size of the invading French.

\section{First act: The revolution and the birth of the First French republic}

Field: Politics of France

Principal actors: The French monarchy, the revolutionaries, the aristocracy, the French military forces, the sans-culottes, the Prussian and Holy Roman Imperial armies.

\section{Mapping out the habitus of the principal actors}

The French monarchy: the French monarchy was amongst the oldest and most prestigious of the royal houses of Europe (Hampson, 1963:5). In the aftermath of the Thirty Years War, the French monarchy emerged as the most powerful actor on the European stage (Kennedy, 1988:74; Kissinger, 1994:65). Yet France did not only dominate the battlefield, but also the fields pertaining to the arts and culture. French was spoken by the nobility throughout Europe, French fashion was widely adopted and French luxury products were sought after by those who could afford them, from Lisbon to Moscow. Under King Louis XIV, the Sun King, France almost attained a position of hegemony in Europe. However, the Kings who followed, Louis XV and Louis XVI were less successful, and were said to have been more interested in the pleasures of life than ambitious power projects (Hampson, 1963:2). France was a frequent participant in major European wars. In the middle of the $18^{\text {th }}$ century, France was defeated in the Seven Years' War against a coalition led by the United Kingdom - the traditional arch enemy. France was left with huge amounts of debt and was left deprived of most of her colonial holdings in India and North America. Numerous attempts at addressing the situation failed. The fiscal situation further worsened, when the French monarchy saw a chance for revenge by supporting the American Revolution. The monarchy sent a decisive intervention force, enabling the American Revolution to prevail (Kennedy, 1988:115). France won the admiration and friendship of the young American Republic, but the cost of war had left the monarchy 
further in debt. As the fiscal crisis worsened, the economy was negatively affected. People all over the realm of France felt the consequences. The monarchy came increasingly under pressure from all sides: those who participated in the Enlightenment debates became increasingly cognisant of the role of finance and economics (McPhee, 2012:44-45). They understood the consequences of the situation, and blamed the monarchy for its inability to address the crisis. On the other side, the aristocracy denied that the monarchy had the right to institute radical administrative reforms on the realm without their consent. Through the so-called Parlements, bodies which allowed the aristocracy to participate in the political process, they repeatedly rejected the proposals of the King. In an attempt to bypass the Parlements, Louis XVI summoned the Estates General, the feudal body purporting to represent all of the realm. The moment the Estates General came together, a chain of events resulted in the start of the French Revolution (McPhee, 2012:48). Attempts at controlling these events failed, and the Monarchy saw herself increasingly in the position of helpless bystander: isolated, always dithering, always a step behind, never able to take the initiative and to lead.

The revolutionaries: The revolutionaries were mostly from among the so-called third estate: the common people. The third estate constituted the great mass of people living in France at the time, making up $97 \%$ of the population. The group included almost everyone, from illiterate peasants to urban based intellectuals. What made these people members of the third estate was the fact that they were not aristocrats, nor were they members of the clergy. The third estate paid most of the taxes, and were legally discriminated against in relation to the two others estates, the aristocracy and the clergy (McPhee, 2012:7). The revolutionaries were the most politically conscious members of the third estate, mostly from intellectual or middleclass backgrounds. However, some revolutionaries also came from the first estate, the nobility, and the second estate, the clergy. The primary factor which brought the revolutionaries together as a group was the belief in the premise of the Enlightenment. Virtually all of them had participated in the Enlightenment debates in the run-up to the revolution (McPhee, 2012:10). Once they understood that the balance of power 
was in their favour, they made sure that knowledge about the Enlightenment would proliferate, thus forever discrediting the feudal social order.

The aristocracy: the aristocracy saw itself traditionally as independent and autonomous. They acknowledged the prestige and position of the King, to whom they swore allegiance, yet they believed to also be equal to the king in terms of rights and legitimacy (Hampson, 1963:2). Traditionally throughout French feudalism, the aristocracy clashed with the monarchy in struggles over rights and duties. During the reign of King Louis XIV, they lost some of their traditional rights and privileges, and so as the French monarchy came under increasing pressure, they hoped to seize the moment and to obtain concessions from the King (McPhee, 2012:9). Right at the start of the first meeting of the Estates General they clashed with the emerging revolutionaries. It was only then that they understood that they had overplayed their hand. They attempted to rally to the king's side, but were overwhelmed by the sheer numbers and dedication of the revolutionaries.

The French military forces: At the outset of the revolution, the military forces stationed in Paris were chiefly made up of three types of units: The Gardes Françaises (French Guards), the Garde du Corps (Body Guard), and the Gardes Suisses (Swiss Guards). The French Guards were a unit pertaining to the regular army of France, the royal army. The private soldiers were recruited throughout France and were from non-aristocratic backgrounds. The officers were mostly aristocrats, but not always. The Body Guard unit was a force made up entirely of aristocrats, and thus seen as exceptionally loyal. The Swiss Guard had a long tradition of serving the French Monarchy, and was understood to be the most effective and loyal unit (McPhee, 2012:241). Soon after the start of the Revolution, the French Guards refused to obey their officers. Many of them joined the revolutionaries. A unit of French Guards was in the vanguard during the storming of the Bastille. The Swiss Guards and the Body Guards remained loyal to the King. However, they were fewer in numbers than the French Guard. They could barely protect the King, and could therefore not be used to re-establish order in Paris once the mob got out of control (Hampson, 1963:74). 
The sans-culottes: The sans-culottes was the term generally used in reference to the poor classes of revolutionary France (Hampson, 1963:105). Culottes were the fashionable knee breeches worn by the aristocracy and the rich from among the third estate. The sans-culottes, accordingly, where those people who did not wear such breeches, as they could not afford them. The sans-culottes included peasants and urban labourers, and constituted by far the largest group of people in terms of numbers present in Paris during the revolution (Hobsbawm, 1996). Mostly illiterate, many lived in relative poverty. In times of economic hardship, they were the ones suffering the most. And thus, when in the run up to the French revolution the economic crisis caused huge increases in bread prices, the sans-culottes were aroused in anger and rage. Before the revolution, they had little political consciousness, as they worried more about day-to-day survival than policy considerations. Yet after the revolution, they turned into a major force in Parisian politics, and thus came to play a pivotal political role (Hampson, 1963:10 7). Those who henceforth aimed at exerting power in Paris, and thus France, depended largely on the support of the sans-culottes.

The Prussian and Holy Roman Imperial armies: All of Europe's monarchies looked on with outrage and shock as the French revolution unfolded. As French noble émigrés arrived in Prussia and the Holy Roman Empire, their respective royal leaders signed a pact promising their support to the French King Louis XVI against the revolutionaries (Bradley, 1999). Both monarchies thus positioned parts of their armies against France, ready to strike should they feel it necessary. Holy Roman Emperor Leopold II hoped it would not come to war, but both monarchs understood that the revolution was a danger to the order of feudalism on which the whole of Europe stood (Roberts, 2015:29).

\section{The performance of power politics during the first act}

After the storming of the Bastille, which traditionally marks the start of the French revolution, a moment of heightened crisis followed which lasted for several months (McPhee, 2012:xv). During this moment of crisis a general feeling of uncertainty took hold of all actors involved. In the countryside, uncertainty about what was happening in Paris led to a state of general panic known as the Great Fear 
(Hampson, 1963: 79). As people did not know what was going on, which stories were true, and what would come next, an epistemological state of nature set in. The most absurd rumours were spread throughout the countryside of France. Accounts of roaming bands of robbers on the loose, tales of an aristocrat plot to starve and kill all peasant and stories about foreign invading armies all fed the Great Fear and led to the creation of vigilante groups and peasant militias. In many areas peasants attacked aristocrats and burned their properties, leading many of the nobility to flee France. In Paris, the King was attacked by mobs of sans-culottes, demanding bread and his relocation from Versailles in the outskirts of Paris, to the Tuileries, a palace in the heart of Paris. As the royal army deserted en masse and joined the revolutionaries, the king was left only with the Swiss Guards on which he could count.

The Great Fear came to an end when the revolutionary de facto state, through the National Constituent Assembly - the revolutionary body which claimed full authority in all matters at this moment of the revolution - declared the end of feudalism and adopted the Declaration of the Rights of Man and of the Citizen (McPhee, 2012:224). Once this initial moment of crisis thus passed, relative normalcy and stability returned to Parisian politics. The revolutionaries and the monarchy found ways of negotiating a future which could foresee a place for them both. In the constitution which followed, the National Assembly was confirmed as the legislative body, while the King was to lead the executive. The King could select his ministers, and retained broad veto powers over the legislative decisions. Moreover, under the command of the Marquis de Lafayette, the French hero of the American Revolution, a middleclass security force was set up to re-establish order in Paris (Hampson, 1963:98).

The new political reality, however, was not a happy one, and failed to deliver the premises the champions of the Enlightenment had hoped for. During most of this first moment of the French revolution, the legislature and the King were at odds with one another (Hampson, 1963:134). The King was the head of the executive, but he was often dismayed at what the legislature wanted him to do. The revolutionaries wanted to rewrite the discourse of French society and remodel it on the Enlightenment, while the King ultimately wanted to preserve traditionalism. For 
instance, regarding how to deal with émigrés; the King wanted to welcome them back, and allow them to return to their positions, while the legislature condemned them as traitors, and demanded the confiscation of their properties and the termination of their rights. Also, reforms concerning the church caused much conflict; revolutionaries wanted radical reforms, de facto cutting off France from the rest of catholic Europe, whereas the King saw his house as a traditional champion of Catholicism.

The common belief which underpinned French society, and which was shattered with the onset of the revolution, nonetheless was reassembled decisively. Royal censorship and content control was abolished (McPhee, 2012:57). Political debate clubs proliferated. New newspapers were founded. The church and monarchy lost their monopoly on education. Guilds were abolished and the was economy liberalised. All people of France were equal in front of the law, and could thus equally aspire to anything worth desiring.

Hope that the constitutional monarchy could establish itself, however evaporated when the King attempted to flee from Paris in the summer of 1791 (Hampson, 1963: 105). Dismayed by the revolutionaries, he was urged to do so by his Queen, Marie-Antoinette, and many other royalists, who argued that he could return to Paris at the head of an allied army. He was caught, however, returned, and then placed under guard while the members of the assembly deliberated over what to do with him. Attempts were made to pardon Louis XVI, and to give the constitutional monarchy another chance. In the eyes of the population, however, the monarchy had lost much trust and prestige - too much. Days after the king is reinstated, anti-royal demonstrations in Paris lead to violent clashes and many dead.

Meanwhile, the Holy Roman Emperor and the Prussian King signed a declaration by which they expressed the support for the French King, and threatened to invade should he be harmed. Yet rather than saving the King and the French monarchy, this resulted in the revolutionaries fearing that all what they had achieved could be undone if they did not defend themselves. In response, the balance of power further shifted towards the radical forces among the revolutionaries (McPhee, 2012:145). The king was in a significantly weakened position. The revolutionaries 
decided to rebuild the armed forces, purged from royalist constituents who had traditionally served as officers.

In April 1792, France declared war against Austria (McPhee, 2012:154). The French planned to invade the Austrian Netherlands, current day Belgium, hoping that the population there would rise up in revolt, joining the revolution. The revolutionaries were conscious of their unique historical opportunity. They were not a repetition of the peasant revolts which plagued feudal Europe now and again. They understood themselves to be liberators of mankind, and were eager to spread the revolution to all corners of the earth (Strachan, 2007).

The opening phase of the war however did not favour revolutionary France. Although the recreation of the French army was initiated before the declaration of war, the new force lacked trained, professional officers and soldiers. As a result, the invasion of the Austrian Netherlands collapsed even before it started (McPhee, 2012:16 8). Worse, the opposing army of the First Coalition (Prussia and Austria) under the leadership of the Duke of Brunswick was able to defeat several French forces with relative easy, capturing several strategic locations in France. The Duke of Brunswick then issued a manifesto, declaring his intention to restore the French King to his prerevolutionary rights, while warning that should harm come to the King, his army would burn down Paris and execute those associated with the revolution (Hampson, 1963:145).

Yet again, rather than intimidating the revolutionaries into surrender, the climate of uncertainty led to a further radicalisation on part of the revolutionaries. Louis, who was nominally in command of the French army, was seen as collaborating with the enemies of France. The Tuileries palace, where the King resided in Paris, was stormed by a mob. Several hundred Swiss Guards were killed in the process, and the King and his family were taken into custody (McPhee, 2012:242).

In September 1792, French army units reassembled and marched towards the rear of the invading army. At the Battle of Valmy, the French were able to beat the Duke of Brunswick (McPhee, 2012:334). Although the French had been fewer in numbers, their soldiers showed a higher level of morale: invigorated by the hope 
which was vested in them, and driven on by the fear of what would await them in defeat, they would not flee and desert. After the opening of the battle, which caused relatively few casualties, the French General Kellermann raised his hat and cried out "Vive la Nation" (Roberts, 2015:32). The cry was picked up by the whole of the army, and repeated again and again. This had a crushing effect on the morale of the Prussian soldiers, and to the surprise of almost everyone, the Duke of Brunswick ordered a retreat, and did not regroup again in France.

The revolution had been saved. The next day, the monarchy was abolished, and the first French republic was declared. The radicals who were in charge now accelerated the transition to a state and a society based on the rationale of reason. The king and the queen were condemned to death, and the army was deployed against royalist rebels throughout France. Examples had to be made; hundreds of thousands of supposed royalist supports were killed and massacred. Participating in an anti-rebel mission in the south of France, was young Napoleon (Roberts, 2015:34).

\section{Second act: from the First French Republic until the Thermidorian Reaction}

Field: Politics of France

Principal actors: The European monarchies, the Jacobin revolutionary faction, the Girondin revolutionary faction, the French aristocracy, the Paris mob.

\section{Mapping out the habitus of the principal actors}

The European monarchies: At the outset of the French revolution, the European monarchies remained relatively passive. The Holy Roman Emperor and the King of Prussia demanded restraint from the revolutionaries, yet hoped they could avoid military confrontation. After the French declaration of War against the Holy Roman Empire, it looked like the combined imperial and Prussian forces could easily restore the old order (Palmer, 1972). However, the defeat at Valmly, the declaration of the republic, and especially the decapitation of French King Louis XVI, united almost all 
of the Western European monarchies in alliance against the French. Spain and Portugal would invade from the southwest, the Italian coalition members from the southeast, the Dutch, Prussian and Imperial forces from the northeast, while Britain would support royalist forces inside of France (Kennedy, 1988:121).

The Jacobin revolutionary faction: At the outset of the revolution, the Jacobin Club brought together a group of deputies of the Estates General, and from among the third estate, for discussion and debate on matters of politics (McPhee, 2012:52). After the disbandment of the Estates General, and the subsequent transfer of the locus of the initiated revolutionary politics from Versailles to Paris, the Jacobin club opened up for general membership. It quickly became associated with radical and emotionally mobilising rhetoric which explored republicanism, universal education and universal suffrage, the separation of church and state, and other radical reforms. Until about summer 1791, after the attempted flight of the King, the Jacobin Club brought together a relatively broad spectrum of revolutionaries. However, the club then bifurcated over the matter of the constitutional monarchy, supporters of which departing to found their own club. Subsequently, the balance of power in the Jacobin Club shifted towards more radical forces. After the fall of the monarchy, Paris based lawyer and outspoken radical, Maximilien Robespierre, became the leader of the Jacobins (Jordan, 1985). The faction which he lead in the National Assembly came to be known as the Jacobins. Although a minority in the Assembly at the outset of the first republic, the Jacobins quickly gained in power by enjoying the support of the sans-culottes. While they were at first weary about war, they demanded ever more radical policies inside France.

The Girondin revolutionary faction: The Girondin was a loose political group of members led by Paris based lawyer Jacques Pierre Brissot (Hampson, 1963:133). They started out as members of the Jacobin Club, but then united in their relatively moderate political views as for politics within France. They were fervent supporters of the revolution, and it was Brissot's original plan to export the revolution by military means (Hampson, 1963:135). They resisted, however, the radical escalation in the wake of the birth of the First Republic. This would eventually bring them into conflict with the more radical Jacobins, led by Maximilien Robespierre. 
The French aristocracy: the French aristocracy by now found itself in a desperate situation. Life as they had known it before had broken down completely (Hampson, 1963:169). They had lost their privileges, their estates and their security from violence. Some joined the revolutionaries. Some tried to organise resistance in France. However, most, who could, fled France. Some ended up as far away as America, as was the case with Talleyrand (Lawday, 2006). As émigrés, they urged all European monarchies to unite and to put an end to the revolution (Bradley, 1999).

The Paris mob: The sans culottes and other popular elements of Paris constituted the decisive moral and material force in Parisian politics. While the Paris mob started the revolution motivated by hunger and desperation, they were transformed into a political force by the revolutionaries, who politicised them (McPhee, 2012:231). Revolutionary politics came to depend more and more on the Paris mob. In the wake of the Brunswick declaration, and the execution of the King, the Paris mob demanded ever more radical politics. Robespierre and the Jacobins proved most astute in mobilising the people of Paris for their cause. The Paris mob thus served somewhat as a political paramilitary force, allowing the Reign of Terror to unfold.

\section{The performance of power politics during the second act}

The French first republic was a moment of tremendous crisis, radicalism and change. After the reversal at Valmy, the Revolutionary army was able to cross the border, invading the Austrian Netherlands and the feudal holdings of the Kingdom of Sardinia in the north of contemporary Italy (Roberts, 2015: 40). By now the French republic was at war against almost the whole of Western Europe: The Holy Roman Empire, the Kingdom of Prussia, the Kingdom of Spain, the Kingdom of Portugal, the United Kingdom, the Kingdom of Sardinia and the Dutch Republic.

Inside France, in the Region of the Vendée, peasants revolted openly in early 1793 against the revolutionary government (McPhee, 2012:252). They resented especially the changes imposed on the Roman Catholic Church. They thus defied the revolutionary government's authority and initiated a guerrilla war known as the War 
of the Vandée. Inspired by this act of defiance, other parts of France revolted, siding with the royalists.

The revolutionary government thus called off further incursions into the lands of its many enemies and focussed on internal suppression of counter-revolutionary forces. The number of dead, including combat casualties, massacres and mass executions on both sides went into the hundreds of thousands: 170,000 according to estimates (McPhee, 2012:254). The Vandée was to suffer the most. The revolutionaries were eager to make an example of the Vendée for all others who dared to consider insurrection. The brutality and scale of destruction was such that the area did not recover for many years to come.

The revolutionary government of the first republic, however, came under additional pressure in the summer of 1793 , when the Paris mob, incited by the socalled Enragés (the enraged ones), rose up once again, demanding price controls and other measures against the rich (McPhee, 2012:297). The Enragés asserted that freedom and equality were only vain phantoms, and that the poor continued in a situation not very different to pre-revolutionary times. The ensuing revolt led to the ouster of the Girondins, allowing the Jacobins to assume full control of the revolutionary state. Robespierre thus attained power on the back the popular force, conditioning ultimately the fundament of power politics in Paris (Jordan, 1985).

In the wake of the revolt, Robespierre was elected to the Committee of Public Safety, a nine (later twelve) member administrative body created by the legislature. The Committee was charged with the role of protecting the republic against internal and external enemies. During the time of war, it was vested with broad supervisory powers regarding military, judicial, and legislative matters. Although it was merely charged with supervising the executive of the republic, it in fact superseded the nominal executive and became the de facto executive power of the republic (Jordan, 1985). Although the Committee consisted of multiple members, Robespierre, who enjoyed the support of the Paris mob, came to dominate the Committee, rising thereby to a position of de facto dictator. 
Facing internal insurrection, and external invasion, the Committee pushed in August 1793 for universal male conscription, the levée-en-masse (Hampson, 1963: 193). All able bodied male citizens were subsequently marshalled to serve as soldiers or suppliers in the war effort. Clausewitz would come to recognise this moment as a break with the mode of war of past times (Strachan, 2007). The levée en masse meant that the whole nation would be involved in war, whereas, before, war was limited to small professional armies led by the nobility. Moreover, these French soldiers were participating in the making of history. Fighting for a cause, as free men, would translate positively into a bolstering of morale.

In September of the same year, the Committee initiated the Reign of Terror. A proclamation announced the policy: "It is time that equality bore its scythe above all heads. It is time to horrify all the conspirators. So legislators, place Terror on the order of the day! Let us be in revolution, because everywhere counter-revolution is being woven by our enemies. The blade of the law should hover over all the guilty." (Jordan, 1985:180)

The committee now swiftly pushed another round of radical legislation. One law which was voted in was the creation of a sans-culottes paramilitary force. The sans-culottes had served as the enabler of the revolution and the ever more radical politics. Now they were organised and armed, while remaining politicised. Together with revolutionary army units, there were tasked with forcing farmers to surrender grain to the revolutionary government (McPhee, 2012:194). Another law that was passed was the law of suspects. The law of suspects enabled the judiciary system to charge suspected counter-revolutionaries with crimes against liberty (McPhee, 2012:195).

Vested with almost limitless powers, Robespierre then moved to further the agenda of the revolution. He was dedicated to Jean-Jacques Rousseau, and aimed at creating a society as described by the Swiss philosopher (Jordan, 1985:31). Robespierre claimed that the premise of the Enlightenment had failed thus far to set in because of traitors to the revolution. Through the law of suspects, thousands would be condemned and guillotined. Unlike before, the state now set about reshaping the 
minds of all subjects of France - by threat of violence. Everyone was to believe in the ideals of the Enlightenment, or else.

Yet as the Guillotine did its deadly work in ever closer intervals, everyone turned into a potential suspect. People could not say anymore what they thought, for fear that someone would denounce them and bring them in front of a popular trial. As the number of guillotined reached into the tens of thousands, and after even many of the earlier central revolutionary leaders were executed, opposition arose to Robespierre, and he himself was eventually decapitated during the Thermidorian Reaction, in the summer of 1794 (Jordan, 1985:206). Everyone was relieved; the end of radical politics was in sight. The first republic had been successful in permanently beating back the counterrevolution, and thus in securing the revolution, yet now the work was done, the revolutionaries were content to return to a semblance of normalcy and moderation.

\section{Third act: From the coronation of Napoleon until the French victory at the Battle of Jena and Auerstedt}

Field: Politics of Europe

Principal actors: Napoleon, the European monarchies, the French aristocracy, the French people, the French army, the European armies.

\section{Mapping out the habitus of the principal actors}

Napoleon: Napoleon was born into a Corsican family of the lower aristocracy. At an early age, Napoleon was sent to a military school in royalist France (Roberts, 2015:13). His dedication and mathematical skills enabled him to enter the prestigious Ecole Militaire in Paris, where he was trained as an artillery officer. At the outset of the revolution, Napoleon came to the attention of Augustine Robespierre, the younger brother of Maximilien Robespierre, for writing a pro republic pamphlet. Subsequently he was tasked with a number of missions on behalf of the revolutionary government of the first republic (Roberts, 2015:33). Briefly met with suspicion for his association 
with the Robespierre, he was eventually allowed to join the preparations for the Italian campaign. In the years that followed, he proved himself to be a military genius. His fame reached Parisian politics, where he became an ambitious actor. He came to power through a coup which made him one of three consuls of the republic. Yet as he outshone the other members, he launched a referendum, which asked the French people whether he should become their emperor. With $99 \%$ of yes votes, Napoleon eventually crowned himself emperor of the French by taking the crown from the pope and placing it himself on his head (Roberts, 2015:46), symbolic of the fact that he obtained the title of emperor based on his own merits and those of the people, as opposed to through some divine birthright. He argued that France must be remodelled after the Roman Imperial System, for only then could France return into the family of European states. He remained committed, however, to the ideals of the Enlightenment, yet also allowed for the part-restoration of the aristocracy. As emperor of the French, he worked towards the continuous reform of French society. Many of the innovations introduced by Napoleon still define the French state today. His legal code, which he exported on the back of his military campaigns throughout Europe, would eventually entrench the ideas of freedom and equality through feudal Europe (Roberts, 2015:361). As a military leader, he was exceptional in every aspect. He was loved by his troops, and he knew how to inspire their imagination. He would ride by his soldiers, talk to them, always concerned for their wellbeing.

The European monarchies: After the treaty of Amiens in 1802, the whole of Europe was at peace for the first time in 10 years (Roberts, 2015:231). The European monarchies were relieved that the most radical politics had ended, yet they resisted acknowledging Napoleon as their peer. Moreover, geopolitical considerations pitted nations against Napoleon, especially the United Kingdom, which had traditionally opposed the creation of a hegemonic actor in the European continent. Thus even before the coronation of Napoleon, The Holy Roman Empire, Russia and the United Kingdom formed the Third Coalition against France (Roberts, 2015:241). The ultimate goal was no longer the restoration of the French monarchy, but the curtailment of the ambitions of Napoleon. 
The French aristocracy: Once Napoleon took power, some aristocrats started to return to France. They saw in Napoleon someone who could lead a reconciliation, and indeed, Napoleon would eventually allow them to restore some of the aspects of life they had lost (Roberts, 2015: 169). Many of the highest noble titles, however, Napoleon gave to his supporters, so that the old high nobility remained removed from their former positions of prestige and influence. Nonetheless, as in the rest of Europe, the nobility once again was allowed to play a central role in politics, diplomacy and the military.

The French people: In the eyes of many people, Napoleon was a hero, and there were many who fanatically admired him. It was this general awe that Napoleon inspired in the huge number of people which made him an untouchable figure politically. He understood that the power of the France, and thus his own power, rested on the people, hence he invested in furthering their welfare. The concordat with the Roman Catholic Church earned him much favour, and allowed for healing of the French nation (Roberts, 2015:443). Napoleon instituted the modern school system of France, and ultimately most of Europe, which was eventually adopted in the years ahead. Napoleon believed in the power of meritocracy, and allowed for the transformation of society.

The French Army: Years of fighting had turned the French army into a veteran force. Napoleon was loved by his men (Roberts, 2015:299). On campaign he would frequently eat with them, converse with them, and he always made sure to listen to their needs, and then to deliver. In return, his men would follow him everywhere, always believing that he was touched by Fortuna. Moreover, Napoleon's belief in meritocracy allowed the French soldiers to rise through the ranks in accordance to skill and courage. He entertained a very close relationship with his top military commanders, the marshals of France (Roberts, 2015:420), many of whom from simple backgrounds, chosen by Napoleon for their skill and competency. As a result, the French military would repeatedly beat opponents greater in size.

The European Armies: The European Armies were forced to react to the many innovations the French introduced. Yet they also clung to many old traditions. Thus, 
command remained in the hands of the high nobility, and meritocracy came less to the fore (Strachan, 2007). The soldiers, different from the French, were not inspired by the premise of a grand cause. Many were forcefully conscripted into the army. The fear exerted by the fame of apparent invincibility of Napoleon had an effect on their morale, and they would often easily break and rout in battles against Napoleon.

\section{The performance of power politics during the third act}

Soon after the establishment of the French empire, the third coalition was formed, and war returned to Europe (Roberts, 2015:237). This time, France saw herself opposed by Russia, the Holy Roman Empire, Sweden and the United Kingdom. The Holy Roman Empire had been part of every coalition thus far, and had many grievances resulting from major defeats. After the war of the second coalition, the holy roman emperor was forced to accept humiliating terms, losing many territories.

Napoleon, who had since the signing of peace (from 1802 when the treaty of Amiens was signed) used the time reorganise France, and to reassemble and further expand the French army. By 1805, the Grande Armée had grown to a force of 350,000 men, well equipped and led by competent officers (Roberts, 2015:252). Moreover, the soldiers of the Grand Armée were confident in their cause, seeing themselves as the only free men in Europe, and who thus would not fight only for France, but for the liberation of the whole of mankind (Strachan, 2007).

Napoleon, confident in the role as military commander, made the first move by marching his army towards the imperial army led by General Mack which was situated in Southern Germany (Roberts, 2015:258). In the campaign that followed, Napoleon cemented his image as a military genius. His objective was to beat the isolated armies of the Holy Roman Empire concentrated in the theatres of southern Germany and Austria, before the Russian army could link up with them. After great preparations, in complete secrecy, Napoleon crossed the Rhine and then swung south towards the imperial army, cutting its communication lines in complete surprise. When General Mack realised what was happening, it was already too late. He was 
completely surrounded. After some brief fighting, Mack surrendered, understanding that his position was hopeless. Napoleon lost 2,000 soldiers, but captured 60,000 imperial soldiers. Napoleon then continued speedily to the Imperial capital of Vienna. He took the city with no resistance. Huge amounts of weapons fell into his hands.

Considering what was happening, the Holy Roman Emperor, and the Russian Tsar, who had arrived, decided that they would seek battle. Napoleon sent the Grande Armée north to meet the coalition armies, but then ordered a feigned retreat in order to lure his enemies into a trap. The coalition armies were unable to see through Napoleon's tricks, and suffered one of the most decisive and consequential defeats of the Napoleonic wars, at the Battle of Austerlitz (Roberts, 2015:268). Once again, a smaller French army completely routed a bigger coalition army. The battle came to be seen as a strategic and tactical masterpiece. A carefully calibrated but dangerous plan compared to the achievement of Hannibal at the battle of Cannae against the Romans (Strachan, 2007).

The Russian army fled back to Russia and the British forces failed to play a decisive role on the continent. The holy Roman Emperor was forced to accept the most drastic terms at the Treaty of Pressburg (Roberts, 2015:270). Under the terms, Napoleon created a series of satellite kingdoms in Western Germany, the Confederation of the Rhine. Fearing that Napoleon would proceed to claim the crown of the Holy Roman Empire for himself, Emperor Francis II abolished the Empire, and established in its place the Austrian Empire. Prussia, meanwhile, was keen to stay out of war. Napoleon rewarded Prussia with Hanover, which he took from the United Kingdom (Strachan, 2007).

Prussia accepted, but in doing so it made itself an enemy of Britain. Suddenly isolated, Prussia saw France encroaching ever closer to its borders. Prussia was an absolutist monarchy, and feared what the revolutionary ideas could mean for its political future. Prussia now made a turnabout and joined the fourth coalition, which was formed only a month after the failure of the third coalition, and which was essentially the same alliance minus the Austrian Empire. Prussia mobilised about half of its available forces and declared war against France in 1806 (Strachan, 2007). 
Napoleon could almost not believe Prussia would be so foolish, especially since most of the Grand Armée was still assembled in Western Germany.

The military confrontation would give Napoleon yet another great victory, showing the world the power of the revolution and the ideas it unleashed. The French army and the Prussian army met at the twin battles of Jena and Auerstedt (Roberts, 2015: 286). The Prussians had approximately double the number of soldiers on their side. However, during the 10 years of peace Prussia enjoyed after it dropped out of the war at the end of the second coalition, Prussia did little to learn the lessons of the revolution. Its soldiers were peasant conscripts and its leaders were aristocrats who were no match for Napoleon's battle hardened commanders (Strachan, 2007).

Napoleon now was at the height of his power. He used the time once more to consolidate his gains by spreading the beliefs of the French revolution. Even though he lost in the end, and the absolutist monarchies could impose the order they wanted, they could never undo the spread of the revolutionary ideas (Strachan, 2007). And eventually, by 1848, virtually every state in Europe was either a republic or a constitutional monarchy. Napoleon may have lost at Dresden and Waterloo, but his ideas about how society should function prevailed, and in due course all absolutist monarchies fell (Hobsbawm, 1996). Napolean may have been defeated eventually on the material battlefield, but the revolutionary ideas underpinning his rise were victorious on the battlefield of the mind.

\section{Analysis of case one: The French Revolution and the rise of Napoleon}

For more than a thousand years, the French monarchy had relied on the dominance of a common belief which ultimately rested on the metanarrative of the divine rights of kings. The divine rights of kings were grounded in claims that God legitimised Kings, the clergy and the aristocracy in their respective positions. During the Renaissance, new ideas were introduced into the discursive structures underlying the social universe of Western Europe. As philosophers, thinkers and others dedicated to the art of contemplation and exchanging of ideas continuously engaged questions of ultimately metaphysical considerations, they came to give rise to the movement of 
the Enlightenment. The Enlightenment focused on many considerations. A central role was commonly attributed to reason. The more reason gained in terms of centrality in organising discourses, the more the rationale of the feudal order was undermined. As more and more people in positions of prominence adapted reason as the ordering principle, the feudal order which had structured the appearance of reality in the foregone centuries was weakened.

When France was hit by a financial and economic crisis, the conditions were created in which the very foundation of the constitution of the social universe of feudal France became open for discussion. A critical number of key actors in the social universe of France were no longer willing to adhere to the rationale of feudalism. As they refused to back off during a brief moment of debate in the context of the Estates General, the metanarrative of the divine rights of kings was deconstructed, and the metanarrative of reason was elevated into a position of sovereignty. This meant that the monarchy lost legitimacy, and that the elites of France came to adhere to reason as the ordering principle. However, when the monarchy fell, the revolutionaries first had to rebuild the state into one through which they could recondition all subjects of France in accordance with the new ideas. Rebuilding was not without its difficulties, as many of the erstwhile dominant actors refused to adhere to the new ordering of the appearance of reality. Resistance to the spread of new ideas was organised. Moreover, the neighbouring states, which all still depended on the position of hegemony of the metanarrative of the divine rights of kings, declared war against the French revolution, determined to stop the spread of the new ideas.

The revolutionaries now saw themselves confronted with two enemies: the enemies within, and the enemies without. Inside France, the revolutionaries were ruthless in their determination to enforce the conditioning of the new beliefs. Brute force was used against anyone who appeared to oppose the new ways of doing things. The most visible representatives of the old order were executed. During the terror, thousands of supposed enemies were killed. On the battlefield, the French revolutionaries almost lost, until at the battle of Valmy, the French general - through the use of language and images - was able to inspire hope in the minds of his soldiers, 
and fear in the minds of the Prussians. Thus, the situation was reversed, and the revolution was saved. In the course of the next years, the French were successfully reconditioned in accordance to the new beliefs. This had two important effects: Firstly, knowledge was organised and employed in a new and systematic fashion: the development of technologies set in, merit came before birth, subjects were reordered in terms of efficiency and impact. Secondly, as the French believe to be in possession of the truth, and on a mission of spreading it, they would unleash energies which the feudal neighbouring states could simply not match. And thus when the military genius of Napoleon took command of France, he could draw on the most formidable, dedicated and self-confident fighting machine Europe had seen in her entire history. The French then swept across Europe, defeating enemy after enemy, instituting the ideas of the Enlightenment wherever they went. After the Battle of Jena and Auerstet, Napoleon was at the height of his power. Although in many ways he reproduced many aspects which had defined the social universe during the feudal order, he inspired in the minds of subjects all over Europe images of liberation and progress. He kept on winning in the years which came, until he overplayed his hand. Yet the ideas of the French revolution, once unleashed, proved impossible to undo. And even

as Napoleon eventually lost on the battlefield, the rest of Europe changed in accordance with his perspectives, and not those of his victorious enemies.

\section{Historical case two: The Soviet Invasion of Afghanistan}

The second case focuses on the Soviet invasion of Afghanistan. The Soviet engagement in Afghanistan is compared to the US war in Vietnam. In both conflicts, a superpower confronted a rag-tag irregular force with limited military capabilities. However, although both superpowers remained uncontested on the battlefield, they lost the war of ideas, which eventually led to them losing the war. The second case, the Soviet invasion of Afghanistan, took place in the backdrop of Détente, a phase of the Cold War when both sides were committed to easing tensions. The Afghan crisis surprised both sides, and contrary to US interpretations of the time, the Soviets were 
reluctant to get involved, as they understood the risks they would face. The Afghan War eventually ended Détente. The Soviets were unable to take control of the situation, as the US and its allies created and supported the Mujahedeen. Unbeknownst to - and unintended by - the planners of the time, the Mujahedeen served as a model for radical terrorist forces, which now plague our own times. Yet, this is not the topic of this case, and thus let us start in the first act with an overview of Afghanistan during the Cold War, followed by act two, which focuses on the time when the communists took power in an attempt to recondition Afghan society through coercive means. In act three we look the war itself, and how the US supported the radicals as a means to weaken to Soviet Union.

\section{First act: The Afghan dream of modernisation and regional autonomy}

Field: Afghan politics

Principal actors: Afghan President Sardar Mohammed Daoud Khan, People's Democratic Party of Afghanistan (PDPA), the traditionalists of Afghanistan, the Central Committee (CC) of the Communist Party of the Soviet Union (CPSU), the government of the United States, the government of Pakistan.

\section{Mapping out the habitus of the principal actors}

Afghan President Sardar Mohammed Daoud Khan: Born a prince, Daoud Khan overthrew the Musahiban monarchy headed by his first cousin Mohammed Zahir Shah and declared himself as the President of the Republic of Afghanistan in 1973. Educated in France in the 1930s, Daoud embarked on a long career in public service from an early age (Ansary, 2014:49). At the age of 25, he took on the governorship of a number of provinces in Afghanistan. In the decades which followed, he served alternately as a commander of military forces, as a diplomatic representative to other nations and as a member of the executive government. In 1953 he was made prime minister. Self-confident and inspired by progressive ideas, Daoud initiated a series of ambitious projects which aimed at modernising Afghanistan. Infrastructure projects were set in motion and traditional beliefs were challenged. Moreover, Daoud was 
intent to assert Afghanistan as an autonomous regional actor, and thus to overcome the country's historical predicament as a contested territory between outside powers (Ansary, 2014:50). Daoud saw in nationalism an important force which he hoped to harness in order to attain his ends. Since most Afghan subjects, as Daoud himself, were Pashtuns, his nationalist discourse centred on promoting the Pashtun people. Daoud challenged the legitimacy of the border separating Afghanistan and Pakistan, the British imposed Durand Line. The Durand Line once demarcated the limits of British Imperial India. The border divided the Pashtuns, who saw themselves as one people. Daoud supported Pashtuns willing to fight against the rule of Islamabad, in favour of joining Afghanistan. Weapons were sent, and fighters were trained (Blood, 2001). This did not only alert Pakistan - which retaliated by training traditionalist Afghans who were opposed to the progressive agenda of Daoud - but also alienated the non-Pashtun populations of Afghanistan. In search of allies, Daoud steered the country ever more in the direction of the Soviet Union. In 1963, Dauod stepped down as prime minister. When he returned to power ten years later, he continued the policies which he had set in motion when prime minister. Now the President of a newly founded Afghan Republic, Daoud styled himself a progressive leader, vigorously pursuing an agenda of economic and social modernisation (Ansary, 2014:60).

The traditionalists of Afghanistan: Alexander the Great, the conqueror of the world, famously said about the area which today constitutes Afghanistan, that it is "easy to march into, hard to march out of" (Robson and Lipson, 2002). Since Alexander, many other conquerors came, each introducing new influences. However, the rugged landscape of Afghanistan always made it difficult for any aspiring ruler to condition Afghan subjects as a whole in a meaningful way (Rashid, 1995:6). Thus, for most of the history of Afghanistan since Alexander, the country had no strong central state. Rather, numerous tribes, clans and other forms of local communities constituted the almost exclusive respective social worlds known by Afghan subjects. This means that power was usually highly decentralised in Afghanistan, whereby particular interpretations of Islam (in Afghanistan more moderate Sufi approaches to Islam were traditionally dominant), specific cultural customs, and distinct ethnic 
identities constituted the beliefs informing the numerous de facto autonomous groups of subjects living in the lands of Afghanistan (Rashid, 1995:44). Afghan leaders, who aimed at a national approach to any given issue, could do so only by going through the tribal institution of the Loya Jirga (Blood, 2001). The Loya Jirga, which means grand assembly, when called, would bring together the Afghan tribal leaders, who would then discuss any issues of interest. Once they came to a consensus, all were expected to adhere to it, and to bring their respective people in line. However, even though Daoud was able to retain the support of the tribal leaders, the growth of communist influence during his rule provoked the rise of Islamist hardliners who denied the authority of the tribal leadership, and legitimised their dissent by referring to the teachings of Islam, which they said were outside of tribal decision making processes. Ironically, many of the early leaders of the Islamic movement were university students who had studied at Kabul university, rubbing shoulders with young communists and foreigners (Ansary, 2014:60).

People's Democratic Party of Afghanistan (PDPA): The PDPA was a socialist party established on 1 January 1965 by Nur Mohammad Taraki and a relatively small number of others (Ansary, 2014:59). Tariki and other likeminded early Afghan communists, such as Mir Akbar Khyber, Hafizullah Amin and Babrak Karmal, were impressed by the progressive communist discourse about social justice and equality, so very different to the hierarchical, conservative and anti-modern realities they knew. Under the regime of the monarchy, the PDPA was tolerated, yet many of its activities were repressed. For instance, their newspaper publications were censored, and they were forced to adopt another name for their organisation, as secularist and antidemocratic manifestations were forbidden (Blood, 2001). Within the PDPA, two factions emerged soon after the founding of the party: Khalq (masses) and Parcham (banner) (Ansary, 2014:60). Most Khalq supporters were Pashtuns and came from rural settings. Parcham supporters, by contrast, were most often from the cities. There were ideological differences between the two factions, with Khalq favouring a Leninist vanguard party state, and Percham favouring a broad Rousseauian mass democracy approach. The two factions were often rivals, yet they were also capable of working together. In 1973 the PDPA assisted Daoud Khan in overthrowing King 
Zahir Shah. The PDPA saw Daoud as a more progressive force. In return, the PDPA was rewarded with posts in the government. Subsequently, the PDPA was able to build up a network of soldiers loyal to its cause.

Central Committee (CC) of the Communist Party of the Soviet Union (CPSU): The Central Committee, according to Lenin, was to be the supreme authority of the Communist Party, the vanguard of political power in the Soviet Union (Fainsod \& Hough, 1979:21). The CC was constituted of a number of important offices, which, when distributed among a number of individuals, allowed de jure for collective approaches to leadership. However, in the history of the Soviet Union, de facto power was most often concentrated in the hands of one person. At the outset of the Cold War, the CC, firmly controlled by Stalin, focused its attention on consolidating its gains in Europe. In the aftermath of the Berlin Crisis, and once France and Britain relinquished most of their colonial empires in the late 1950s and the early 1960s, the CC, now under the leadership of Khrushchev, recast its attention onto the so-called third world (Leffler and Westad, 2010a:2-12). From the 1960s onwards, the CC competed with the United States for influence over the third world. A mix of diplomacy, clandestine activities, development aid and military assistance was deployed, with the goal of securing client states. In Africa and the Middle East, as well as other parts of the world, a series of client states were successfully brought into the Soviet orbit. In Central Asia, not much had changed since the days when the Russian empire participated in the so called Great Game against the British Empire. Secession attempts by non-Russian populations around the Caspian Sea in the immediate aftermath of the communist revolution of 1917 were contained, and their lands then reintegrated as Republics into the Soviet Union. The Soviet Union, thus, as the Russian empire before, bordered on the relatively autonomous states of Persia and Afghanistan. The ouster of Khrushchev as the preeminent leader of the Soviet Union in 1964 was followed by a period of collective leadership, until in the early 1970s Leonid Brezhnev established himself as the central figure. Under Brezhnev, the CC was committed to Détente, while simultaneously building up the Soviet Union's military capabilities (Leffler and Westad, 2010b:14-16). The global strategy of support for client states was continued, albeit less aggressively. Whereas, before, the 
Soviet Union would aid anyone who would appear with a red flag in hand; now, great power relations were more important, and thus stability was an objective in itself. In Central Asia, the CC entertained friendly relations with the Afghan government of Daoud, offering aid in many areas. This strategy seemed to bear fruits when Daoud accepted Soviet assistance in his drive towards securing more autonomy for his country as an actor in the region.

The government of the United States: The US government recognised at the outset of the Cold War the importance of Afghanistan to its strategy of containing the Soviet Union (Leffler and Westad, 2010a:35). In doing so, the US gave continuity to the strategic approach already pioneered by the United Kingdom in the nineteenth century. Shortly after the start of the Cold War, successive US presidents courted the Afghan leadership. President Eisenhower visited Kabul in the late 1950s, and Afghan king Zahir Shah was received by Kennedy a few years later in return. The king visited Disney Land, an Afghan flag was taken to the Moon, and pictures were taken of the Central Asian country from outer space. In the course of time, a series of programmes were initiated which saw the establishment of an ever growing US presence in Afghanistan (Ansary, 2014:50). These programmes continued even when Daoud deposed the Afghan king. By 1970, numerous American teachers, engineers, doctors, scholars and diplomats lived and worked in Afghanistan. Afghanistan was a popular destination for explorers and hippies travelling to the Far East in search of spiritual refreshment - and the US government encouraged such exchanges. However, as the US government gave priority to the military alliance with Pakistan, military aid to Afghanistan remained very limited. Moreover, the governments of Nixon, Ford and Carter were all committed to Détente, an attitude towards the Soviet Union which sought to avoid direct conflict, while allowing for a more flexible diplomatic approach. Hence, these governments were happy to avoid introducing instability into Central Asia (Tanner, 2009:230).

The government of Pakistan: Pakistan was born as an independent nation only in 1947. The rationale behind the creation of Pakistan was neither the idea of creating a nation state, nor did it rest on natural borders. Pakistan was supposed to be the home of the Muslim populations of the British Indian Empire. It encompassed the 
lands of modern day Pakistan, then known as West Pakistan, as well as modern day Bangladesh, which was then known as East Pakistan. Right from the outset as a sovereign state, Pakistan was plagued by problems of contested borders, and questions about the rights of sectarian groups within the lands over which it claimed sovereignty (Blood, 1994). The border between West Pakistan and India would be redrawn several times. East Pakistan would eventually secede in the early 1970s. In the west and northwest of Pakistan, the borders in place - most (in)famously, the Durant Line - had been drawn by the British empire in the $19^{\text {th }}$ century, and divided the Baluchi people and the Pashtun people from their kin in Iran and Afghanistan. Both of these ethnic groups within the territory of Pakistan had their grievances, and felt that the government of Islamabad was dominated by the Punjabi and Sindhi interests, the two other major ethnic groups of Pakistan. As a result, there were many Baluchis and Pashtuns who entertained dreams of more autonomy, or - in the case of the Pasthun people - reunion with their kin in Afghanistan. In order to overcome divisions given by ethnic identity, the government of Pakistan supported a strong role for Islam in Pakistan. It was hoped that by appealing to Islam as a common identity, union between the different peoples could be achieved (Ansary, 2014:69). Moreover, differently to India, which hoped to remain in a position of non-alignment (although with a certain bias in favour of the Soviet Union), Pakistan quickly came to establish significant relations with the United States. In the course of the 1950s, Pakistan became a main ally of the United States in the region (Kissinger, 1994:527).

\section{The performance of power politics during the first act}

The late 1960s and early 1970s marked the onset of Détente, a period in the Cold War when both super powers were willing, or even eager, to ease tensions (Leffler and Westad, 2010a: 3-16). US Presidents Nixon, Ford and Carter worked together tacitly with preeminent Soviet leader Brezhnev in allowing for the conditions of possibility of Detanté (Scott, 2007:41). Through a series of treaties, including SALT and the Helsinki Accords, it was hoped that Détente could become a fixed condition, thus ensuring co-existence between the two nuclear armed super powers. However, while the super powers opened up more direct relations and were 
committed to avoid direct confrontation, indirect struggle persisted. Both the Soviet Union as well as the US remained actively engaged in the affairs of many states around the world. Most prominently, the US continued their engagement in Vietnam, defending the so-called free Vietnam from a supposedly aggressive North-Vietnam, which received indirect assistance from the Soviet Union (Kissinger, 1994:643-702). Moreover, although forces in favour of cooperation in both governments were able to steer events, there were also those who remained committed to devising means to weaken and undermine the adversary. Zbigniew Brzezinski pioneered strategies which foresaw the encouraging of nationalism and Islamism in Central Asia. The idea was it to turn the non-Russian people against the Soviet Union (Scott, 2007:50). However, Brzezinski would have to wait until the election of Carter until he could implement his ideas.

In Central Asia, in the early 1970s, things appeared relatively stable. Persia and Pakistan were both firm US client states. Afghanistan enjoyed relative autonomy in the region (Tanner, 2009:226). However, the 1960s Afghan strategy of encouraging a Pashtun rebellion against Pakistan had the effect of moving the country ever more into the orbit of the Soviet Union (Ansary, 2014:57). As the United States was a friend of Pakistan, Afghanistan could only look to the Soviet Union in search for aid. Daoud Kahn, after coming to power again in 1973, continued to entertain relations with both super powers, the United States and the Soviet Union, in an attempt to reduce reliance on the Soviet Union. Daoud invited and encouraged aid programmes from both sides. From his perspective, the United States and the Soviet Union both could both be useful in his aspirations for developing the country's economy and infrastructure. Additionally, both seemed appealing in their potential to challenge the traditionalist hold on society and encourage more modern and progressive ideas.

In terms of foreign policy in the region, Daoud continued the policy of proxy conflict with Pakistan (Ansary, 2014: 71). Daoud gained in an immediate sense, in that he was able to present himself as the champion of the Pashtun cause, thus harnessing the power of nationalism which such as stance brought him. In terms of power politics in the region, the plan was also attractive in light of the prospect of annexing the large part of land on which the Pakistani Pashtuns lived, which could 
have significantly shifted the balance of power towards Afghanistan. The programme escalated when Pashtun rebels killed members of the Pakistani political elite. In retaliation, Pakistan intensified its training programme of Afghan traditionalists, and especially Islamists, opposed to Daoud. Some of those trained included Jalaluddin Haqqani, Ahmad Shah Massoud and Gulbuddin Hekmatyar, who were all key figures in the bourgeoning radical Islamic scene which was positioning itself against communist influences entering Afghanistan (Ansary, 2014: 72).

Meanwhile, Daoud also became weary of the growing influence of the Afghan communist party PDPA. Accepting advice from the Shah of Persia, Daoud slowly began to move against the PDPA members in the government and the military (Scott, 2007:55). Understandably, this change of posture, together with the cooling off in relations towards the Soviet Union, had an antagonising effect on Afghan communists.

The death of prominent communist Mir Akbar Khyber in 1978 thus caused the PDPA leadership to fear that Daoud was planning to kill them all (Jervis, 1983:7273). Taraki, Amin and others accused Dauod of being behind the death of Khyber, calling on supporters to protest in the capital. In reaction, Dauod ordered the arrest of PDPA leaders. Amin, however, was only placed under house arrest. From home, he was able to call on his contacts in the military, ordering them to move against Dauod. A coup, which had already been prepared and planned during the years before, was set in motion. The Saur (Pashtu for April) revolution resulted in the death of President Daoud, who, together with many members of his family, was shot when soldiers loyal to the communists attacked his palace. The PDPA was able to secure power and install Taraki as the supreme leader of Afghanistan (Tanner, 2009:230).

These events had a strong effect on super power relations. The US saw the communist coup as the result of Soviet strategy. However, contrary to US views, the revolution was in fact not encouraged by the Soviet Union, which feared the ensuing fallout from instability and was interested in continuing Détente (Scott, 2007:55). 


\section{Second act: The communists take power in Afghanistan}

Field: Afghan politics

Principal Actors: Nur Muhammad Taraki, Hafizullah Amin, Babrak Karmal, Central Committee (CC) of the Communist Party of the Soviet Union (CPSU), the government of Pakistan, the government of the United States, the government of Saudi Arabia, the Mujahedeen of Afghanistan.

\section{Mapping out the habitus of the principal actors}

Nur Muhammad Taraki: Taraki was a founding member of the Afghan communist Party, and part of the Khalq faction. At an early age, he was introduced to communist ideas by Indian communists when he was in Bombay working for a trading company (Ansary, 2014:57). Upon his return to Afghanistan, he agitated for communist ideas. He wrote books and authored poetry which brought him to fame. At first, he was tolerated by the monarchy. Due to his language skills, he was even brought into the service of the government and was sent to the Afghan embassy in the United States. However, his continued opposition to the monarchy led to his dismissal. He was ordered to stop his activities, yet he was not arrested. After the demise of the monarchy, Taraki, holding a top position in the communist party, tacitly supported the Government of Dauod, which employed many communists in government. However, as Daoud moved against the communists, in the wake of the death of Mir Akbar Khyber, a prominent Parcham communist, Taraki was in the vanguard of those accusing the government. In the aftermath of the Saur revolution, Taraki saw himself catapulted into the position of supreme communist leader of the newly founded communist Afghan state (Ansary, 2014:61).

Hafizullah Amin: Amin, a Pashtu like Taraki, was educated in mathematics at the University of Kabul (Ansary, 2014:62). After teaching in his country, he went to the United States where he earned a Masters degree in education at the Columbia University in New York. Ironically, it was there, in the heart of global capitalism, where Amin turned into a radical Marxist. He returned to Afghanistan where he met Taraki. The two subsequently became close. A few years later he returned to the US 
in pursuit of a $\mathrm{PhD}$ degree. However, he neglected his studies, dedicating himself instead to the further study of communist theory and radical politics. On his return to Afghanistan, he stopped by in Moscow, where he was further strengthened in his commitment to bring communism to Afghanistan. Upon arriving back in Afghanistan, he acceded to the communist party and became involved with politics as a member of the Khalq faction. During the rule of Daoud, Amin became the second in command of the Afghan communist party after Taraki. Amin focused his attention on organising the communists in the Afghan army. He was very successful in finding members and organising them into cells loyal to him. Thus, when Daoud moved against the communists, it was Amin who gave the orders to communist army elements to launch the Saur revolution (Ansary, 2014:61). Once Taraki was in power, Amin became his chief aid and encouraged a cult of personality around Taraki.

Babrak Karmal: Karmal was the son of a relatively wealthy non-Pashtun family from Kabul. His father was a high general officer in the Afghan army and a former governor. Kamal enjoyed high school at a German college in Kabul and then went to university for an education in law and political science. Early on he was part of student unions, which made him suspicious in the eyes of the authorities. He was arrested and imprisoned. In prison he met Mir Akbar Khyber who introduced him to Marxism. After he was released, he dedicated himself to the spreading of communism. After the Afghan communist party was founded by Taraki, Karmal joined the party. However, his views differed from Taraki's, whereupon he became the leader of the Parcham faction of the Afghan communist party, rivalling Taraki's Khalq faction. The Parcham attracted urban born communists, and was more moderate than the rival Khalq faction. As a result, the Parcham were more open to working with the Daoud government. After Taraki and the Khalq faction came to power, Kamal and other Parcham found themselves purged. Many Parcham, including Kamal, went into exile in the Soviet Union (Ansary, 2014:64). As the Soviet Union watched the Khalq leadership unfold, they came to favour Kamal and the Parcham faction of the Afghan communist party, which they saw as more considerate and better able to govern the country (Scott, 2007:55). 
Central Committee (CC) of the Communist Party of the Soviet Union (CPSU): The Soviet Union was taken by surprise by the Saur revolution. Even though relations with Daoud were deteriorating in the run-up to the revolution, Dauod was still seen as a desirable leader, responsive to Soviet wishes, even if only tacitly. Once the revolution took place, however, the Soviet Union had a greater interest in getting further involved. The Soviets at first hesitated to commit to military involvement in Afghanistan, instead calling on Taraki to moderate his policies. The Soviets were committed to Détente, and feared that a major military involvement in Afghanistan could undermine super power relations, as well as agitate the Muslim populations of Central Asian (Leffler and Westad, 2010b:324).

The government of Pakistan: Just before the coup, the Pakistani leadership had come to an agreement with Dauod which would see the end of the proxy conflict. The potential for Pashtun rebellion was thus expected to decrease (Blood, 2001). However, once the communists took power, the Pakistani government under General Muhammad Zia ul-Haq was eager to counter the spread of communism. Haq was bound to radical Islamism, and thus readily drew in the networks which were already in place against the Afghan communist government. Haq understood the struggle as one which pitted two beliefs against one another: Islam and communism. In a sense, both beliefs have in common that they potentially can overcome differences in ethnic identity, and thus can serve in uniting diverse groups. Haq feared that some of Pakistan's restless minorities, especially the Baluchi in the southwest, could come to adhere to communism, thus threatening the integrity of the Pakistani state. For Pakistan, therefore, there were several incentives to activate its assets and increase its power in the region through the spread of radical Islam (Tanner, 2009:250).

The government of the United States: The US government was at first hesitant to judge the Saur revolution. Carter's foreign secretary Cyrus Vance and national security advisor Brzezinski offered competing accounts of interpretations. Brzezinski eventually prevailed in reaching Carter (Scott, 2007:91). He argued that the revolution was engineered by the Soviet Union. National security circles feared that the Soviet Union would absorb Afghanistan, which could then be used as a bridgehead for further expansion southwards. Essentially, the argument mirrored the 
fear Great Britain had during the Great Game: the Russians aspired to reach the Indian Ocean, and undo the strategy of containment (Brzezinski, 1998). Brzezinski, schooled in political science, history and geopolitics, and a keen expert on the region, came to play the central role of orienting US policy in Central Asia. Brzezinski argued that the US should support the burgeoning movement of Islamic opposition to the communists. He argued that through such measures the Soviets could be dealt "their Vietnam". A series of programmes were initiated which would encourage the further spread of radical Islam. In doing so, cooperation with Saudi Arabia and Pakistan was sought out (Scott, 2007:77).

The government of Saudi Arabia: Saudi Arabia was not directly affected by the events in Central Asia. However, the Saudis saw themselves as the patrons of radical interpretations of Islam, Salafism. This stance had a very particular historical root: The house of Saud came to power in the aftermath of the First World War, when the royal family to be made a pact with the radical movement of Wahhabism. According to this pact, the Saudis were to take the throne and, in return, they would give the Wahhabists a relatively free hand in defining the belief systems inside Saudi Arabia and also support the ambitions of the Wahhabists in spreading their radical interpretation of Islam to others parts of the world (Rashid, 1995:44). For a long time, the consequences of this deal were limited to Saudi Arabia, whereas the rest of the world was little affected. Yet as radical Islam started to play a role in world politics, the Saudi government invested millions in the spread of radical Islam in Central Asia (Rashid, 2002:78). Also, many Saudi citizens were set to play a major role. Among these pivotal Saudi enablers of radical Islam were Abdullah Azzam and Osama Bin Laden (Scheuer, 2008:83).

The Mujahedeen of Afghanistan: The Mujahedeen were enabled already during the Daoud government, when traditionalists favouring Islam opposed the growing influence of communism (Ansary, 2014:67). Ironically, however, the future leaders did not emerge from among the tribes, which were most directly affected by the climate of change of beliefs. Rather, most future rebel commanders came from the University of Kabul, where they had been radicalised. During the reign of Dauod, these future Mujahedeen played a minor role. Daoud sought to modernise 
Afghanistan, and thus was in theory also an enemy of adherents to radical interpretations of Islam. Yet Dauod always acted with the consent, at least tacitly, of the tribal leadership. However, once Daoud was gone, in the wake of the Saur revolution, the Mujahedeen were already in place to take on a bigger role through armed resistance (Rashid, 2010).

\section{The performance of power politics during the second act}

The Saur revolution came at an unexpected moment. Triggered by the death of prominent Afghan Parcham communist Mir Akbar Khyber, the events which followed played out in such a way that the communists were ultimately able to take power and install themselves in the government, unopposed by other parties. Taraki, once in power, set out to implement a series of radical reforms (Barfield, 2010: 229235). The name of the country was changed to the Democratic Republic of Afghanistan (DRA). Taraki introduced women to political positions and legislated an end to forced marriages. He also started efforts of increasing literacy, and initiated programmes with the aim of indoctrinating subjects with Marxism. A friendship treaty with the Soviet Union was signed. Relations with the United States were not cut off, but those with the Soviet Union were significantly expanded.

Uncompromisingly opposed to traditionalism and Islam, the Taraki government acted ruthlessly against the traditional societal structures of Afghanistan. The PDPA, under Taraki, started to promote state atheism. Women were banned from wearing the burqa. Men were obliged to cut off their beards. Girls and boys from all classes and backgrounds were obliged to attend school. Mosques were closed and declared off limits. Moreover, the PDPA carried out an ambitious land reform programme, whereby farmers' debts countrywide were waived, usury was abolished, and land was redistributed.

Those seen as representing the old system, such as tribal leaders and Islamic authorities, as well as those who did not accept the reforms, were dealt with severely. Within a short time span, tens of thousands of traditionalists were arrested, many were killed (Tanner, 2009:231). These brutal measures, dishonouring Islam, together 
with the sweeping land reforms, disrupting the lives of Afghan subjects, quickly resulted in a widespread rebellion against the Taraki government. Thus, less than a year after taking power, the communist government's hold on the rural lands of Afghanistan was contested. The ranks of the Mujahedeen were filled with soldiers, while the Afghan army was plagued by widespread desertion. The war between the Mujahedeen and the communist government had begun.

The Pakistani government, under the leadership of Muhammad_Zia-ul-Haq, a committed enemy of communism, was eager to support the Mujahedeen and to aggressively spread radical interpretations of Islam. Networks, which had already been created in response to Daoud's proxy war with Pakistan, were extended and used to supply the Mujahedeen with arms and training. Almost simultaneously, Brzezinski encouraged President Carter to follow suit, and to support the Mujahedeen. Brzezinski argued that such a move would provoke the Soviets to intervene, which then would lead them to have their own "Vietnam" experience (Scott, 2007:85).

In reaction to these developments, Taraki requested military assistance from the Soviet Union. However, Brezhnev was reluctant to provide this (Barfield, 2010:237). He understood that a Soviet intervention was very risky, and moreover that, as he told Taraki, it would not solve Afghanistan's problems, while potentially bearing the eternal hatred of the Afghan people. Brezhnev advised Taraki to moderate his policy approaches, and to seek broader public support for his reforms. However, while Brezhnev hoped to remain uncommitted, he also understood that if he did not help the young communist regime, Afghanistan would certainly be lost. Thus the gradual commitment of the Soviet Union to Afghanistan was set in motion.

Meanwhile, the relationship between Taraki and Amin soured (Ansary, 2014:65). Amin had enabled the coup, and had subsequently acted as main advisor to Taraki. He also encouraged a cult of personality around Taraki. Yet to Amin's surprise, the cult of personality led Taraki to believe that he really was the genius he was portrayed to be (Ansary, 2014:62). Taraki turned away from Amin, discarding his advice. A struggle for the control of the Afghan army ensued. As the disagreement between the two erstwhile allies escalated ever more, Taraki planned to 
have Amin killed. In September 1979, Taraki invited Amin to his palace for talks. Amin first turned down the invitation. However, the Soviet ambassador, who unbeknownst to Amin was a co-conspirator of Taraki, encouraged Amin to accept, and to go to the palace in the company of the Afghan chief of police and a high ranking member of the Afghan secret service. Upon arrival, Amin and his group were received by shots fired at them. Amin was able to get away unhurt, while one of his companions was killed. He subsequently rallied Afghan military units, returned to the palace, and arrested Taraki. Unsure what to do with him, he consulted Brezhnev, who told him that he must decide himself what to do. Amin interpreted this answer as having the backing of the Soviet Union, and so decided to have Taraki killed (reportedly by suffocation with a pillow) (Tanner, 2009:233).

Having obtained the position of supreme power, Amin started out by moderating the communist rule in an attempt to win back the support of the Afghan people, which he understood to have been lost by the hostile communist position towards Islam under the leadership of Taraki. Amin promised religious freedom, allowed for the repairing of mosques, presented copies of the Qur'an to religious groups, invoked the name of Allah in his speeches, and declared that the Saur Revolution was based on the principles of Islam. Moreover, he presented himself as a pious Muslim, and started to appear in public dressed in traditional Pashtun attire, while reaching out towards nonaligned powers (Ansary, 2014:65; Tanner, 2009:233)). While these moves may have allowed him over time to counter the anti-communist discourse, which declared that communism was atheistic, western and against Afghan traditions, it did not elevate his position in the eyes of the Soviets. The Soviets had established a special commission on Afghanistan. The commission concluded that Amin's allegiance to Moscow was feigned, and that he was in fact looking towards Pakistan and the People's Republic of China. The Soviets thus planned to intervene with a small elite force, to remove Amin from power and install Babrak Karmal from the more moderate Parcham faction of the PDPA (Barfield, 2010:237).

Operation Storm-333 took place on 27 December 1979 (Tanner, 2009: 235236). The Soviets relied on a small unit of special forces, numbering around 660 well trained men. The operation was executed swiftly. Faced with very limited resistance, 
the Soviet commandos penetrated the Afghan presidential palace where Amin stayed with his family, killing over 200 of his guards. Still believing that the Soviets supported him, Amin at first did not believe that he was the target. Only after he failed to contact the Army leadership, did he understand that his end had come. Amin was subsequently killed. On the same day, a pre-recorded message was played through the Afghan radio network. In it, the voice of Babrak Karmal proclaimed: "Today the torture machine of Amin has been smashed, his accomplices - the primitive executioners, usurpers and murderers of tens of thousands of our fellow countrymen - fathers, mothers, sisters, brothers, sons and daughters, children and old people are no more." (Braithwaite, 2011:103). Babrak Karmal was at that moment still outside of Afghanistan. He would enter the next day accompanied by major Soviet military forces. The full-scale Soviet intervention in Afghanistan had begun.

\section{Act three: The Mujahedeen insurgency}

Field: Great Power Politics

Principal actors: The Afghan Communists, the Afghan Mujahedeen, the Arab Afghans, the Central Committee (CC) of the Communist Party of the Soviet Union (CPSU), the government of Pakistan, the government of the United States.

\section{Mapping out the habitus of the principal actors}

The Afghan Communists: The Afghan communists found themselves in a difficult situation after the Soviet intervention. The radical programmes initiated after the Saur revolution did not bring about the reconditioning of Afghan society as hoped (Ansary, 2014:63). While in the cities they enjoyed significant support, Islamic rebellion in the countryside was spreading. The mighty Soviet army promised to safeguard them, and to squash the rebellion. Yet in their reliance on the Soviet army, they became completely dependent on the Soviet Union. As the war intensified, they played a secondary role, at the side of the Soviets, who took all important decisions. However, for obvious reasons, it was always important for both partners to portray the Afghan communists as being in charge of events (Blood, 2001). 
The Afghan Mujahedeen: Gulbuddin Hekmatyar, Ahmad Shah Massoud, Burhanuddin Rabbani and other afghan Islamic fundamentalists already stirred against Daoud, and then received support and training from Pakistan (Barfield, 2010:213). When the Afghan communists took over, they were already committed and organised to take up the fight. They often had very different ethnic and tribal backgrounds, but were united in their fight for the Islamic cause. They did not organise themselves in a clear hierarchical organisation, but rather, could be understood as warlords, each of them commanding their individual armies. This meant that it was much more difficult to undermine the Mujahedeen and destroy them as an organisation. As one warlord was taken out, others were there to take his place (Kaplan, 2006).

The Arab Afghans: The Arab Afghans were the foreigners who joined the Mujahedeen in their fight against the communists. The name is somewhat confusing since not only Arabs joined the struggle for Islam, but rather Muslims from all over the world. Key figures were Abdullah Yusuf Azzam and Osama Bin Laden. Azzam was a Palestine born radical and early intellectual pioneer of global Jihad (Scheuer, 2008:83). Expelled from several countries, he moved to Saudi Arabia in the 1970s where he was a teacher of Osama Bin Laden. When the Islamic resistance took shape in Afghanistan, he organised the first networks which would see others willing to fight for Islam joining the Afghan Mujahedeen. It was also Azzam who convinced Bin Laden to join him in Afghanistan. The Afghan Arabs thus understood themselves to be on a global mission, and saw the Soviet invasion as a key moment for promoting their goals (Scott, 2007:87).

Central Committee (CC) of the Communist Party of the Soviet Union (CPSU): Once committed, the Soviet Union was unable to leave Afghanistan. Brezhnev had been hesitant to support the Afghan communists when they first requested massive military aid (Ansary, 2014:64). Yet as the Afghan communists committed one blunder after another, creating a large-scale uprising in Afghanistan, the Soviet leadership felt that it had no choice but to support their ideological brethren in the Central Asian country. Moreover, the Soviets feared that if Afghanistan fell to radical Islamists, then their Central Asian Soviet Republics would also become threatened 
(Leffler and Westad, 2010b:234). Thus, once inside Afghanistan, the stakes were high. Defeat would mean humiliation and could potentially threaten the whole of the Soviet Union.

The government of Pakistan: Strongman General Haq, and his chief of the Pakistani secret service (the ISI), General Hameed Gul, were the key actors in the early stages who organised the Islamic resistance in Afghanistan (Tanner, 2009:250). They supported the Mujahedeen with intelligence, training and resources. They also linked up the Afghan Arabs, and thus made it possible for the world's radical Islamic movement to get involved in the war against the Soviets.

The government of the United States: The US government, following the lead of Brzezinski, was keen to make sure that the Soviet invasion of Afghanistan would fail (Scott, 2007:55). Whereas the Pakistanis were in the lead in operational terms, the Americans were the most important contributors of material factors, such as money and weapons. However, the US was also very conscious of the ideational factors involved. It was understood that there were alternatives to radical Islam, and that it would have been possible to promote nationalist or tribal values in the fight against the Soviet Union (Scott, 2007: 85). However, Brzezinski and others felt that by encouraging radical Islam, a broader front against the Soviet Union could be mobilised. In fact, Korans were translated into other Central Asian languages, including Uzbek, and were distributed throughout the region (Scott, 2007:90). Also, the US had its own assets of radical Islamists, whom they encouraged through the alFarook mosque in Brooklyn, New York, a recruitment centre for radical Islamists willing to travel to Afghanistan and fight the Soviets (Scott, 2007:89). Additionally, while the Pakistanis were in the vanguard of training efforts, the US had its own training programmes. Islamist fighters were brought to the US for training, and US trainers went to Afghanistan, where they trained the Mujahedeen. In doing so, the choice of weapons was carefully considered so as to allow the Mujahedeen to take out even heavy weaponry, such as helicopter gunships and tanks. Meanwhile, through the enlistment of Hollywood, the Mujahedeen were portrayed as freedom fighters, opposed to an odious repressor. 


\section{The performance of power politics during the third act}

President Carter, in the wake of the Soviet invasion, denounced the Soviets, declared the mass crossing of Soviet troops into Afghanistan to be the gravest threat since World War Two, and enabled the expansion of an aid programme for the resistance. The CIA operation, Operation Cyclone, was born. In the course of the following years, the US would come to spend hundreds of millions of dollars in support of the Mujahedeen (Scott, 2007: 89). The Soviet invasion of Afghanistan would thus result in the end of Détente (Leffler and Westad, 2010b:40).

Immediately after crossing with significant military forces into Afghanistan, the Soviets were able to easily attain most military objectives, securing the cities and main infrastructure. The next step proved to be more difficult. The Mujahedeen were based in the countryside, and would avoid open battle (Tanner, 2009:241). The war thus essentially came down to a war of ideas. Daoud and the Afghan communists both wanted to roll back the influence of Islam and traditionalism which had dominated Afghanistan for centuries, and then recondition the Afghan subjects in accordance with modern - ultimately western - ideas. Daoud did so with regard to existing structures. Taraki, however, used brute force. Due to the repressive and brutal methods especially of the Taraki government, an adverse effect was created, whereby the Afghan people rallied to the flag of Islam, while denouncing outside ideas. Moreover, as the Mujahedeen hid among the civil population in the countryside - and indeed was part of that population - Afghan communist and Soviet attacks against suspected rebels often led to more outrage, and to a further weakening of the communist cause.

The Soviet plan was to rebuild the Afghan army, and then to provide decisive force in a supporting role, while the Afghan army would do the main work of conquering Mujahedeen controlled areas, and then holding them. However, that plan proved unworkable, and the Soviets had to conduct many offensives themselves. Often they would conquer an area, only for the Mujahedeen to quickly retake it when they left. The Soviets thus realised that they would have to get their hands dirty: intimidation tactics were developed, subversion was deployed, and suspected 
Mujahedeen were imprisoned and tortured (Tanner, 2009:261). However, such actions only resulted in making the Mujahedeen cause more legitimate, in Afghanistan, and internationally.

Meanwhile, the US, Pakistan and the international Islamic brigades expanded their programmes. The US had a key role in promoting the cause of the Mujahedeen as just to the rest of the world, while also contributing with money and weaponry (Leffler and Westad, 2010b:427). For instance, the Hollywood action hero Rambo

fought in one of his engagements on the side of the Mujahedeen against Soviet troops, which were portrayed as savage and brutal.

Year after year of brutal fighting went by. Seemingly, the harder the Soviets pushed, the harder the resistance responded. As the Soviets attempted to stop the resistance, it made its fighters appear as martyrs. The image of the modern Soviet style New Man, which Taraki and to a certain degree Daoud once wanted to institute in Afghanistan, appeared to be the enemy of the people. Thus while the Soviets were drawn ever more into the insurgency, and the US and other supporters of the Mujahedeen made sure money and weapons kept flowing, while promoting the image of the nobility of the cause, the idea of the Soviet New Man found itself deconstructed, while Islam gained in terms of acceptance by the subjects of Afghanistan. After a decade of Soviet engagement in Afghanistan, the Soviet army left, demoralised and beaten (Tanner, 2009:270).

\section{Analysis of case two: The Soviet Invasion of Afghanistan}

In the wake of the Second World War, the Soviet Union and the United States engaged in a struggle for who's perspective would eventually be seen as the true perspective on how reality is supposed to be structured. As the two locked horns ever more emphatically, Europe - historically the centre of world power - took on a lesser position. By the 1960s, Europe had relinquished her colonial holdings all over the world (Keene, 2002). As the many new members of the international society sought to establish themselves, US and the SU competed over patronage. As we have argued, global governmentality measures were used, in a direct and indirect fashion, with the 
goal of conditioning the newly independent, supposedly sovereign, states. Some of the newly formed states firmly embraced one or the other super power. Others attempted to go a third way, the way of autonomy and non-alignment.

In Central Asia, Afghanistan was a special case. Never having been a colony, the Central Asian country looked back to a history of fierce rejection of outside influence. Traditionalism, Islam and tribal identities formed the dominant belief systems of the fragmented groups of subjects living on the lands of Afghanistan. However, as other states around the world attempted to modernise, Afghan rulers attempted to follow in the same direction. Daoud, first as prime minister, then as de facto presidential dictator, attempted to set up a state apparatus through which he could recondition the subjects of Afghanistan in accordance with modern ideas. Inside Afghanistan, he sought the consent of traditional power structures by drawing on the traditional institution of the Loya Jirga. Outside Afghanistan, he encouraged the deployment of aid and development programmes as offered by the Soviet Union and the United States. From his perspective, both super powers could contribute in terms of ideas and material which would make the transition to modernity possible. However, Daoud also wanted to encourage nationalism. Whereas inside Afghanistan this brought him popularity and legitimacy, outside Afghanistan, in relation to its neighbour Pakistan, this strategy backfired. As Pakistan retaliated to Daouds encouragement of Pashtun rebellion in Pakistan, through the encouragement of radical Islam inside Afghanistan, Daoud set forces in motion which he could not control. Pushed in search of help towards the sphere of influence of the Soviet Union, as the US was already set on the side of Afghanistan, the communists grew in power and influence. When Daoud consequently tried to undo this trend by purging the communists from power, he was purged from power instead.

The Saur revolution brought the communists to power in Afghanistan. The communists shared with Dauod the desire to recondition the Afghan people. However, the Taraki government was not willing to achieve the desired ends by way of working through existing power structures, and used brute force instead as a main approach to governmentality: traditional ways were forbidden, and everyone was forced to go to school so as to be reconditioned in accordance with the ideas of communism. This 
approach had quite an adverse effect. Contrary to the intentions of the government, the idea of modernism, and eventually, the ideal of the Soviet man, was gravely discredited, while the ordering ideal of Islam gained in strength. As the situation got out of control, the communists committed one blunder after another. The Soviet Union, at first unwilling to engage, saw no other way than to intervene in order to make sure that Afghanistan would not fall into the orbit of another power, or worse, become a breeding ground for radical Islamism, which then in turn could come to pose a danger to its Central Asian Soviet Republics.

The intervention of the Soviet Union led the United States in turn to react by initiating a programme which would see the promoting of Islam as the dominant factor conditioning the beliefs of Afghan subjects. The US could have chosen another approach, such as the promotion of nationalism, or traditionalism. However, the promotion of radical Islam appeared more interesting: Firstly, it made it possible for the US to join forces with Pakistan and Saudi Arabia, which both aimed to promote radical Islam. Secondly, radical Islam could then potentially be further encouraged to weaken the Soviet Union by spreading to the Central Asian Soviet Republics.

In sum, Daoud tried to custom tailor the appearance of reality to the subject within his reach in accordance with the ideas of modernism. However, he ultimately failed to manage the inherent complicated relations of inviting the United States and the Soviet Union to his country, while accommodating traditional structures of power . Quite unintentionally, the communists, which he first believed to be using for his ends, came to power. The communists, assertive in their desire to radically recondition the Afghan people, also ended up quite unintentionally to strengthen the beliefs they had declared most unwanted: those of radical Islam. Ironically, the US, which had played an important role behind the scenes in that outcome, by employing its subjective power capabilities in support of radical Islam, also came to achieve an end which was quite unintentional: The idea was to portray Islam as a liberating force against the oppressive domination of the Soviet Union. However, as the Soviet Union left the stage of world history, radical Islam remained, and has in the meantime set its eyes on the United States and the West in general. 


\section{Conclusions}

Kant's inquiry into the relationship between reason and reality led him to conclude that humans cannot aspire to know the real world as it is itself, but can only come to know an appearance of the world which they themselves construct. Subjects produce reality by integrating representations of the world provided to them by their sensory organs into concepts which they cherish a priori to the moment of cognition. Subjects can strive to steadily improve the knowledge from which they derive their concepts, and thus can come to have an ever more sophisticated understanding of reality, yet they can never come to know the real, objective world, as it is in itself. They are forever limited to deal with what is eventually always only the appearance of reality. In the process of production of reality, subjective considerations thus dominate objective considerations: From the Kantian perspective, the object must conform to the subject. Reality, as it appears, is constructed in the minds of cognizing subjects.

Some continental philosophers, who followed in the path Kant had prepared, accepted his conclusions according to which the world which can be grasped, and the world as it is itself, would forever be separated by an unbridgeable gulf. Yet with these limitations in mind, they hoped that mankind, working together in concert, could come to craft a universal body of knowledge which is true in relation to the world which can be grasped. Through time, and by the steady application of the experimental method, mankind could unlock the secrets of the phenomenal world. Neokantians, thus in a sense, returned on a path which claimed to be able to establish universal and necessary claims about the workings of the social universe. The neokantian approach thus one again led to a perspective whereby the object structures the subject. The concepts, upon which cognizing subjects depend when producing reality, could be derived from sound, universal knowledge which is universally and necessarily true about the phenomenal world. Structuralist approaches to the social sciences, including neorealism, are intellectual children of the neokantians.

Other continental philosophers who followed in the wake of the philosophical revolution of Kant, accepted his conclusions yet denied the claim to the possibility of 
the attainment of universal knowledge. Nietzsche made the point most forcefully, arguing that there is no universal perspective, but rather a manifold of perspectives. What is true depends on perspective, and perspectives come about by what is held to be true. Power, moreover comes to play an important role: Truth comes about as the result of power struggles where dominant perspectives prevail against weaker ones. As perspective conditions truth, truth conditions perspective. The powerful impose their perspectives onto the others. What appears to be real and true is thus conditioned by power.

Postmodernists, following in this train of thought, argue that truth, and thus appearance of the world, are the results of power struggles. Subjects, in cognising the phenomenal world in which they are placed, draw on concepts which are not derived from an universal body of knowledge, but rather, subjects derive the concepts on which they depend from certain beliefs they cherish as the outcome of conditioning and shaping efforts as conducted by others, and individual, particular circumstances. Thus by changing the beliefs subjects cherish about the world a priori, the manner in which reality appears to them can be changed. Postmodernists disagree on whether actors can aspire to consciously and intentionally interfere in the process of the production of reality.

However, a critical rereading of classical realism from the perspective of postmodernism has uncovered the concern of classical realists with the relation between beliefs and power. Hobbes argues that if there is no consensus common belief, conflict and struggle is likely. Indeed, he argues that with different beliefs present in a common space, with no power deciding on who is right, subjects may end up in conflict for defensive considerations, i.e. in defence of their views, or for offensive considerations, i.e. to spread their views. Hobbes thus argues that the Leviathan must concern himself with intentionally conditioning and shaping the beliefs of the subjects within its control. Or rather, certain truth must be upheld and enforced, while others have to be discouraged and banned. Other thinkers seen as canonical classical realists, including Machiavelli and Clausewitz recognize the importance of subjective considerations, and call for intentional action on part of the power conscious subject. 
By drawing on governmentality as conceptualised by Michell Dean, it is possible to imagine how an epistemological leviathan could look, i.e. the systematic, large scape shaping of subjects in accordance to desired beliefs; the brining about of a custom tailored reality. One the one hand, such is necessary so as to make possible common existance. On the other hand, the reality which comes about is always to the advantage of some and to the detriment of others. Every state, or rather the group of subjects in charge, ultimately privileges a particular set of beliefs. These privileged beliefs are defended and promoted as the truth. Through the state apparatus, subjects are conditioned in accordance to desired assemblages of beliefs. Subjects thus do not develop their perspective on the social universe sui generis, but rather, what they believe to be true is the outcome of programmes and other conditioning factors guided and controlled by a powerful few. Ideally, from the perspective of those conducting the conductors, are subjects wholly docile, unquestionably cherishing the beliefs advocated by the state apparatus.

However, because subjects can draw on language in imagining events which take place in spatiotemporal configuration other than presently experienced by the thinking subject, and since subjects are always eventually cherish misconceptions about the social universe in which they are placed, actors who seek to mobilise subjects through fear and hope are always given a means to disturb and unsettle the status quo. Or rather, even the most thoroughly shaped subjects never are fixed in terms of the beliefs they cherish about reality a priori. Through concerted action by interested actors, subjects may at any time can be mobilised so as to serve in a desired role. In times of crisis, subjects are more easily reached, whereas in times when they feel secure, they may ignore attempts at mobilizing them.

Through the method of Bourdieu we can understand how struggle in the subjective sphere can affect material factors in world politics. Bourdieu argues that reality comes about as a dialectical relationship between subjective factors and objective factors, whereby the reality as it appears to subjects is ultimately conditioned by subjective factors, which, however, in turn are constrained by objective factors as they exist in themselves. Or rather, the terms in which subjective factors, which inform humans on sense, legitimacy and meaning, can be articulated, 
are delimited by objective factors and the distribution thereof. The conditions of possibility for beliefs are thus always constrained. Bourdieu offers a set of thinking tools which allow for reflection on the performance of subjects engaging each other in world politics (or any other stage). The conceptual tool of the field comes about when two or more subjects compete for a stake. The field is shaped by the distribution of material factors among competing subjects. Interaction is governed implicitly and explicitly accepted rules, the doxa. The stake, the shape of the field and the governing doxa may all constitute targets for competing actors, which all cherish their own individual habitus. The habitus reflects the beliefs cherished by subjects, and comes about as a process of exposure to society as well as the particular history own to each subjects. The manner in which the field is cognized is thus conditioned by the particular habitus own to each actor. That means that each actor may see a different reality, aims for different overall goals, or has a different sense of what is legitimate, even though when engaging in the same field. Competition for the tailoring of the appearance of reality is a constant factor in world politics.

In reflection of the French revolution and the rise of Napoleon, we conclude that the mobilising power of language and the capability of the state to shape subjects were both decisively employed. Once the grand narrative of the feudalism cracked under the arguments of the Enlightenment, the ensuing revolution brought to power groups of subjects which were ready to use all means available in order to change the doxa - the common beliefs cherished by subjects making up the nation of France.

However, the outcomes did not always correspond with the intentions. Robespierre was momentarily able to enforce a regime of truth which he dictated. Anyone who would oppose the new mode of cognition would face death. Fear of death made people comply with Robespierre, until fear was so widespread, even among his companions. They therefore acted with the desire to save themselves by guillotining Robespierre. By the time Napoleon rose to power, the state had already decisively reshaped French society. Not as radical as Robespierre would have hoped, yet more in harmony as the transition from one belief system to another one demanded. Nonetheless, by the time Napoleon came to power, the French people had been significantly reconditioned: traditionalism was pushed aside as a major source 
informing systems of belief, and the Enlightenment narrative had taken hold: The French soldiers under Napoleon believed they were part of a unique moment in history, liberating mankind. They would thus fight harder and braver than the armies of the other monarchies. Moreover, Napoleon was the God of War in the eyes of many - enemies and friends alike. He could inspire hope in his troops, and fear in those of the enemy. Moreover, even as Napoleon conducted himself in many ways similar to the absolutist monarchies which France had deposed, he was seen as something different, inspiring and heroic - the Weltgeist zu Pferde, as Hegel would write. Napoleon understood the importance of subjective factors, and thus was always concerned with how he presented himself to others, and with instituting programmes, in France and in conquered Europe, which promoted the conditioning of subjects in accordance to what he believed to be true and desirable.

In Afghanistan, successive governments between the 1960s and the 1980s intended to recondition the subjects living within reach in accordance with modernist ideas ultimately emanating from the West. However, after the Saur Revolution brought the communists to power, who enforced radical reforms through brute force, things took quite a different turn. The communist used force in order to recondition the Afghan people in the shortest imaginable possible time in accordance to the ideal of the New Soviet Man. Crudely and clumsily, the number of killed and imprisoned quickly rose into the thousands. Outraged, people flocked in ever greater numbers to the banners of traditionalism. Opposition came from many corners - nationalist ideas, tribal identities, religious considerations. However, the decision as to which of these currents would come to constitute the champion of the opposition to communist regime was not for the Afghans to decide themselves. Pakistan had an interest in furthering Islam as the dominant factor in the Afghan common beliefs. The United States, seeing a chance to deal the Soviet Union a severe blow, joined forces with Pakistan and thus initiated programmes which saw the encouraging and training of those fighting in the name of radical interpretations of Islam. Not only was it probably most convenient to join forces with the ally Pakistan, but also, the spread of radical Islam promised to undermine the Soviet Union in other territories as well, such as the Uzbek Republic, the Tajik Republic and the Turkmen Republic, all of 
which were in the immediate neighbourhood of Afghanistan. The reality of the Afghan social universe was thus custom tailored to the strategic aims of the USA. However, quite different to the original intentions, the monster which was created eventually came to turn against its own creator. The fallout is still defining the agenda of the world politics of security.

In our own times, states are ever more successful in shaping the subjects within their reach. This is especially true in Western states, which are also active in shaping other non-Western populations through global approaches to governmentality. To that end, Western values are declared to be universal, and as such are hard-coded into the guiding framework underlying the UN and international law. The Western way is the universal way, and thus all must be conditioned in accordance with it.

Through the means of the mobilising power of language, moreover, it is always possible to make subjects question the status quo, and come to act according to a desired path. As fewer and fewer things can be said to be real and true, everything is becoming possible. The challenge is only to construct images which have a desired effect. The potential for blowback is always present. Thus, we may conclude in reference to Clausewitz, who argues that strategies are plans towards a desired goal. However, once they are implemented, everything changes, as other actors react to the strategising actor with counter actions. We thus may intend to arrive at an end, such as reconfiguring appearance, yet we never can be sure whether we get there ultimately. When the United States thus supported the Mujahedeen, the intention was to create the appearance of reality for Afghan subjects, wherein the Soviet Union is the enemy. However, once thousands of fighters had been conditioned in such a manner, they remained on their path, even as the Soviet Union was gone. Hence, they shifted their attention to other targets. And thus, in our own time, the original intention of the creators of these programmes has ceased to make any sense, and the outcome has been quite different from that intended.

Through the use of subjective power, it is thus possible to custom tailor the beliefs which inform subjects a priori about reality as it appears to them. However, history has shown that doing so is a very delicate process, and especially in the domain of world politics, the outcome is often quite different from the intentions. 
However, as ever more people are connected to the internet, have access to TV, and have become in a general sense more politically and socially awakened, the potential for attempts at custom tailored reality has become greater than ever. Through the means of global governmentality, indirectly and directly, powerful actors can aspire to condition whole populations, over time, in accordance with their desired beliefs; beliefs informed by value frameworks and ideology which are eventually alien to the targeted groups of subjects. Moreover, through the mobilising power of images and language, actors can at any moment challenge the status quo beliefs, and have subjects act in desired ways. Since direct confrontation between great powers becomes ever more unimaginable, for the outcome could be the end of the world, it can be assumed that struggle in the subjective domains is set to intensify. The fallout might be a world in which nothing anymore is true, and everything is possible. 


\section{Bibliography}

Ansary, T. (2014) Games without rules: The often-interrupted history of Afghanistan. United States: PublicAffairs,U.S.

Aylesworth, G. (2015) Postmodernism. Available at: http://plato.stanford.edu/entries/postmodernism/ (Accessed: 15 March 2016).

Barfield, T. (2012) Afghanistan: A cultural and political history. United States: Princeton University Press.

Barthes, Roland. Mythologies. (1972) The Noonday Press: New York.

Benneyworth, I. (2011) The 'great debates' in international relations theory.

Available at: http://www.e-ir.info/2011/05/20/the-\%E2\%80\%98greatdebates\%E2\%80\%99-in-international-relations-theory/ (Accessed: 5 March 2016).

Bigo, Didier. (2011) Pierre Bourdieu and International Relations: Power of Practices, Practices of Power. International Political Sociology, 5: 225-258. doi: 10.1111/j.1749-5687.2011.00132.x.

Bourdieu, Pierre. (1998) Practical Reason : On the theory of action. Redwood City: Stanford University Press.

Bourdieu, P. and Wacquant, L. (1992) An invitation to reflexive sociology. Cambridge: Polity Press.

Bradley, Owen. (1999) A Modern Maistre: The Social and Political Thought of Joseph de Maistre. Lincoln: University of Nebraska Press.

Bradsher, Henry S. (1983) Afghanistan and the Soviet Union. Durham: Duke Press Policy Studies.

Braithwaite, Rodric (2011). Afgantsy: The Russians in Afghanistan, 1979-1989. Oxford University Press.

Bristow, W. (2010) Enlightenment. Available at: http://plato.stanford.edu/entries/enlightenment/ (Accessed: 6 June 2016). 
Buroker, Jill Vance. (2006) Kant's Critique of Pure Reason: An Introduction. Cambridge: Cambridge University Press.

Buzan, Barry. (1997) Rethinking Security after the Cold War, in: Cooperation and Conflict 32 (1), S. 5-28.

Buzan, B., Waever, O. and de Wilde, J. (1997) Security: A new framework for analysis. Boulder, CO: Lynne Rienner Publishers.

Buzan, B. and Hansen, L. (2008) The evolution of international security studies. Cambridge: Cambridge University Press.

Brzezinski, Zbigniew. (1997) The Grand Chessboard: American Primacy And Its Geostrategic Imperatives. New York: Basic Books

Brzezinski, Z.K. (1970) Between two ages: America's role in the technetronic era. 3rd edn. New York: New York, Viking Press.

Bull, H. (1982) The Anarchical Society: A Study of Order in World Politics. London: Macmillan.

Churchill, W. (2013) The river war: An account of the Reconquest of the Sudan. United States: Skyhorse Publishing.

Clausewitz, Carl von. (1984) On War. New Jersey: Princeton University Press.

Coll, S. (2004) Ghost wars: The secret history of the CIA, Afghanistan, and bin laden, from the soviet invasion to September 10, 2001. United States: Penguin Books.

Cox, Robert (1983) Gramsci, Hegemony and International Relations: An Essay in Method. Millennium, 12 (2), pp. 162-75.

Dean, Mitchell. (2010) Governmentality: Power and Rule in Modern Society. London: SAGE Publications.

Der Derian, James and Shaprio, Mike. (1998) International/Intertextual Relations: Postmodern Readings of World Politics (Issues in World Politics).

Devetak, Richard. (2005) Postmodernism. In Theories of International Relations, edited by Scott Burchill, Andrew Linklater, Richard Devetak, Jack Donnelly, 
Matthew Paterson, Christian Reus-Smit and Jacqui True, 161-187. New York: Palgrave McMillan.

Donnelly, Jack. (2005) Realism in Theories of International Relations, edited by Scott Burchill, Andrew Linklater, Richard Devetak, Jack Donnelly, Matthew Paterson, Christian Reus-Smit and Jacqui True, 29-54. New York: Palgrave McMillan.

Durkheim, É. (2008) The elementary forms of religious life. Oxford, England: Oxford University Press.

Dupre, L.K. (2004) The enlightenment and the intellectual foundations of modern culture. New Haven: Yale University Press.

Easthope, Antony. (1998) Postmodernism and Critical-and Cultural Theory in the Routledge Companion to Postmodernism Edited by Stuart Sim, 15-28. London: Routledge.

Edelman, Murray. (1971) Politics as Symbolic Action: Mass Arousal Quiescence. New York: Academic Press.

Edelman, Murray. (2001) The Politics of Misinformation: Communication, Society and Politics. Cambridge: Cambridge University Press.

Foucault, Michel. (1995) Discipline \& Punish: The Birth of the Prison. New York: Random House.

Friedrich Wilhelm Nietzsche and Walter Arnold Kaufmann. (1974) The Gay Science; With a Prelude in Rhymes and an Appendix of Songs. New York: Random House.

Gardner, S. (1999) Routledge philosophy guide Book to Kant and the critique of pure reason. London: Taylor \& Francis.

Gill, S. (2002) Constitutionalizing Inequality and the Clash of Globalization In International Relations and the New Inequality, edited by Mustapha Kamal Pasha and Craig N. Murphy, 44-65. Oxford: Wiley-Blackwell Publishing.

Gilpin, Robert (1983) War and Change in World Politics. Cambridge: Cambridge University Press 
Grant, Ian Hamilton. Postmodernism and Politics in the Routledge Companion to Postmodernism. Edited by Stuart Sim, 28-40. London: Routledge, 1998

Haqqani, H. (2005) Pakistan: Between mosque and military. Washington, D.C.: Carnegie Endowment for International Peace.

Hart, Kevin. (2004) Postmodernism beginners guide. Oxford: Oneworld Publications. Hicks, Stephen. (2004) Explaining Postmodernism: Skepticism and Socialism, from Rousseau to Foucault. New Berlin: Scholarly Publishing.

Hobbes, Thomas. (1969) The Elements of Law: Natural \& Politic, edited by Ferdinand Tönnies. London: Frank Cass.

Hobbes, Thomas. (1904) Leviathan: Or the Matter Forme \& Power of a

Commonwealth, ecclesiastical and Civil. London: Cambridge University Press.

Hobsbawm, Eric J. (1987) The Age of Empire: 1875 - 1914. New York: Pantheon Books.

Hobsbawm, Eric. (1996) The Age of Revolution: 1789-1848. London: Random House. Hobson, John and Sharman, J.C. (2005) The Enduring Place of Hierarchy in World Politics: Tracing the Social Logics of Hierarchy and Political Change. European Journal of International Relations 2005 11:63.

Hampson, Norman. (1975) The French Revolution: A Concise History. London: Scribner.

Hampson, N. (1963) A social history of the French revolution. London: Routledge.

Israel, J. (2014) Revolutionary ideas: An intellectual history of the French revolution from the rights of man to Robespierre. United States: Princeton University Press.

Jones, Steve. (2006) Antonio Gramsci. London: Routledge.

Jordan, Davis. (1985) The Revolutionary Career of Maximilien Robespierre. New York: The Free Press.

Kant, Immanuel. (1998) Critique of Pure Reason. Trans. and ed. Paul Guyer and Allen W. Wood. New York: Cambridge University Press. 
Kant, Immanuel. (1967) Letter to Marcus Herz. May 26 1789. Philosophical Correspondence. Chicago: University of Chicago Press.

Kaplan, R.D. (2006) Imperial Grunts: On the ground with the American military, from Mongolia to the Philippines to Iraq and beyond. United States: Random House.

Keegan, J. (1993) A history of warfare. 2nd edn. New York: Distributed by Random House.

Keegan, J. (2000) The First world war. New York, NY: Knopf Doubleday Publishing Group.

Keene, E. (2002) Beyond the Anarchical Society: Grotius, Colonialism and Order in World Politics. Cambridge: Cambridge University Press.

Kennedy, Paul. (1989) The rise and fall of great powers. New York, Vintage Publishing.

Kenkel, Kai Michael. (2005) Whispering to the Prince: Academic experts and national security policy formulation in Brazil, South Africa and Canada. Geneva, University of Geneva.

Kors, A.C. (2003) Encyclopedia of the Enlightenment. Oxford: Oxford University Press.

Kissinger, Henry. (2014) World Order. New York: Penguin Press.

Knutsen, Torbjorn L. (1998) A History of International Relations Theory. New York: Palgrave MacMillan.

Khodorovich, S. (1998) 1917-1987: Unsuccessful and tragic attempt to create a "New Man. Available at: http://www.roca.org/OA/76-77/76f.htm (Accessed: 10 May 2016).

Krasner, Stephen. (1985) Structural Conflict: The Third World against Global Liberalism. Berkley: University of California Press.

Krause, Keith. (1999) Rationality and Deterrence in Theory and Practice. In Contemporary security and strategy. Basingstoke: Macmillan. P. 120-149 
Linklater, Andrew. (1990) Beyond Realism and Marxism: Critical Theory and International Relations. London: The McMillan Press Ltd.

Larner, Wendy and Walter, William. (2004) Global Governmentality. London: Routledge

Latour, Bruno. (2005) Reassembling the Social: An Introduction to Actor-NetworkTheory. New York: Oxford University Press.

Lawday, David. (2006) Napoleons Master: A Life of Prince Talleyrand. New York: Thomas Dunne Books.

Leffler, M.P. and Westad, O.A. (eds.) (2010) The Cambridge history of the cold war: Origins, 1945-1962: V. 1. Cambridge: Cambridge University Press.

Leffler, M.P. and Westad, O.A. (eds.) (2010) The Cambridge history of the cold war:

Volume 2, crises and detente: V. 2. Cambridge, UK: Cambridge University Press.

Levi-Strauss, C. (1963) Structural anthropology. United States: Basic Books.

Library of Congress and Blood, P. (2001) Afghanistan: A Country Study. Available at: http://countrystudies.us/afghanistan/29.htm (Accessed: 31 May 2016).

Library of Congress and Blood, P. (1994) Pakistan: A Country Study. Available at: http://countrystudies.us/pakistan/ (Accessed: 31 May 2016).

Luchte, J. (2007) Kant's critique of pure reason: A reader's guide. Continuum International Publishing Group.

Lyotard, J.-F. (1984) The Postmodern condition: A report on knowledge (theory and history of literature series). 8th edn. Minneapolis: University of Minnesota Press.

Machiavelli, N. (1999) The prince. London, England: Penguin Books.

Madden, Thomas. (2013) The Concise History of the Crusades. Lanham, Rowman \& Littlefield.

Malpas, Simon. (2003) Jean-François Lyotard. New York: Routledge.

McGann, James G. with Sabatini, Richard. (2011) Global Thinktanks: Policy Networks and Governance. London: Routledge. 
McPhee, P. (ed.) (2012) A companion to the French revolution. United Kingdom: Wiley-Blackwell (an imprint of John Wiley \& Sons Ltd).

Mearsheimer, John. (2014) The tragedy of great power politics. New York: W. W. Norton \& Company.

Molloy, Sean. (2006) The Hidden History of Power Politics: A Genealogy of Power Politics. New York: Palgrave.

Montefiore, S.S. (2014) Stalin: The court of the red Tsar. United Kingdom: Phoenix Morgenthau, H.J.J. (1973) Politics among nations: The struggle for power and peace. 5th edn. New York: New York, Knopf .

Mills, Sara. (2003) Michel Foucault. London: Routledge.

Nietzsche, Friedrich and Kaufman, Walter. (1974) The Gay Science. New York: Vintage Books.

Norris, Christopher. (2002) Deconstruction: Theory and Practice. New York: Routledge.

Nownes, Anthony J. Total Lobbying. New York: Cambridge University Press, 2006.

Nye, Joseph S. and Welch, David A. (2012) Understanding Global Conflict and Cooperation: An Introduction to Theory and History. New York: Pearson.

Onuf, Nicholas. (1998) Constructivism: A User's Manual. In International Relations in a Constructed World, edited by Kabalkova, V., Onuf, N., and Kowert, P. New York: M.E. Sharpe.

Palmer, Alan. (1972) Metternich, Councillor of Europe. London: The History Book Club.

Pashakhanlou, A.H. (2009) Comparing and contrasting classical realism and Neorealism. Available at: http://www.e-ir.info/2009/07/23/comparing-andcontrasting-classical-realism-and-neo-realism/ (Accessed: 5 March 2016).

Pomerantsev, Peter. (2015) Nothing is True and Everything is Possible. London: Faber \& Faber Limited. 
Popkin, Richard. (1979) The History of Skepticism from Erasmus to Spinoza. Berkeley: University of California Press.

Porter, R. (2001) Enlightenment: Britain and the creation of the modern world. London: Penguin Books Ltd

Pouliot, Vincent and Mérand, Frédéric. (2013) Bourdieu's concepts In Bourdieu in International Relations: Rethinking key concepts in IR, edited by Rebecca AdlerNissen, p24 - 44. New York: Routledge.

Pritchard, D. and Turri, J. (2014) The value of knowledge. Available at: http://plato.stanford.edu/entries/knowledge-value/ (Accessed: 20 April 2016).

Rastovic, Milos. (2011) Kant's Copernican Revolution. Philosophy Study, Vol. 2, No.

\section{1, 19-26. David Publishing.}

Reus-Smit, Christian. (2005) Constructivism. In Theories of International Relations, edited by Scott Burchill, Andrew Linklater, Richard Devetak, Jack Donnelly, Matthew Paterson, Christian Reus-Smit and Jacqui True, 188-202. New York: Palgrave McMillan.

Rashid, A. (1994) The resurgence of central Asia: Islam or nationalism? United Kingdom: Zed Books.

Rashid, A. (2002) Taliban: Islam, Oil and the New Great Game in Central Asia. London: I.B. Tauris Publishers

Rashid, A. (2010) Taliban: Militant Islam, oil and fundamentalism in central Asia, Second edition. 2nd edn. United States: Yale University Press.

Rockmore, Tom. (2006) In Kant's Wake. Oxford: Blackwell.

Rockmore, Tom. (2007) Kant and Idealism. New Haven: Yale University Press.

Rockmore, Tom. (2005) On Constructivist Epistemology. Lanham: Rowman \& Littlefield.

Rosenau, Pauline Marie. (1992) Post-Modernism and the Social Sciences: Insights, Inroads and Intrusions. New Jersey: Princeton University Press. 
Rösch, F. (2014) Best friends forever? Classical realism and critical theory. Available at: http://www.e-ir.info/2014/06/20/best-friends-forever-classical-realismand-critical-theory/ (Accessed: 20 February 2016).

Rousseau, J.J. (1968) The Social Contract. Middlesex: Penguin Classics.

Royle, Nicholas. (2003) Jacques Derrida. New York: Routledge.

Russell, B. (2008) The problems of philosophy. Wilder Publications, Limited, United States.

Said, Edward (1979). Orientalism. New York: Random House.

Scheuer, M. (2008) Imperial hubris: Why the west is losing the war on terror. United States: Potomac Books.

Schrift, Alan. (2010) The History of Continental Philosophy: Volume 1: Kant, Kantianism and Idealism: The Origins of Continental Philosophy. Chicago: University of Chicago Press.

Schrift, Alan. (2010) The History of Continental Philosophy: Volume 2: Nineteenthcentury Philosophy: Revolutionary Reponses to the Existing Order. Chicago: University of Chicago Press.

Schrift, Alan. (2010) The History of Continental Philosophy: Volume 3: The New Century: Bergsonism, Phenomenology, and Responses to Modern Science. Chicago: University of Chicago Press.

Schweller, Randall. (1996) Neo-Realism's Status Quo Bias: What Security Dilemma? Security Studies, Vol. 5, No. 3; pp. 90-121.

Schwitzgebel, E. (2015) Belief. Available at: http://plato.stanford.edu/entries/belief/ (Accessed: 20 Mai 2016).

Scott, Peter Dale. (2007) The Road to 9/11: Wealth, Empire, and the Future of America. Berkley: University of California Press.

Spence, Jonathan D. (1999) Mao. London: Wiedenfeld \& Nicolson. Spinks, L. (2003) Friedrich Nietzsche. United States: Routledge. 
Sim, Stuart. (1998) The Routledge Companion to Postmodernism. London: Routledge. Strachan, Hew. (2007) Clausewitz's On War: A Biography. New York: Grove Press.

Strachan, H. and Herberg-Rothe, A. (eds.) (2007) Clausewitz in the Twenty-First century. Oxford: Oxford University Press, USA.

The Guardian and Irwin, R. (2001) Is this the man who inspired bin laden? Available at: http://www.theguardian.com/world/2001/nov/01/afghanistan.terrorism3 (Accessed: 16 May 2016).

Tanner, S. (2009) Afghanistan: A military history from Alexander the great to the war against the Taliban. Philadelphia: Da Capo Press.

Trotzki, Leon. (2006) From October to Brest-Litovsk. Middlesex: The Echo Library.

Tucker, Robert W. (1979) The Inequality of Nations. New York: Basic Books Inc.

Taylor, V.E. and Winquist, C.E. (eds.) (2000) Encyclopedia of Postmodernism. London: Routledge.

Tylor, Edward Burnett. (1974) Primitive culture: researches into the development of mythology, philosophy religion, art and custom. New York: Gordon Press.

Tyson, Lois. (1999) Critical Theory Today: A User-Friendly Guide. New York: Garland Publishing Inc.

Vogt, K. (2014) Ancient skepticism. Available at: http://plato.stanford.edu/entries/skepticism-ancient/ (Accessed: 15 March 2016).

Wallerstein, I. (2004) The uncertainties of knowledge. United States: Temple University Press, U.S.

Wallerstein, I. (2004) World-systems analysis: An introduction. 5th edn. Durham: Duke University Press Books.

Wallerstein, I. (2006) European Universalism: The rhetoric of power. United States: New Press, The.

Wæver, Ole. (2012) Aberystwyth, Paris, Copenhagen: the Europeanness of new "schools" of security theory in an American field. In Arlene B. Tickner and David L. 
Blaney (orgs.), Thinking International Relations Differently. New York: Routledge; pp. 48-71.

Walker, R. B. J. (2010) After the Globe Before the World. Abingdon: Routledge.

Walker, R. B. J. (1993) Inside/Outside: International Relations as Political Theory. Cambridge: Cambridge University Press.

Waltz, Kenneth. (1979) Theory of International Politics. New York: McGraw-Hill.

Wedgwood, C. V. (2005) The Third Years War. New York: The New York Review of Books.

Williams, M.C. (2005) The realist tradition and the limits of international relations. Cambridge: Cambridge University Press

Williams, Michael. (2007) Realism Reconsidered. Oxford: Oxford University Press.

Woods, Ngaire. (1999) Order, Globalization, and Inequality in World Politics. In Inequality, Globalization, and World Politics, edited by Andrew Hurrell and Ngaire Woods, 8-35. Oxford: Oxford University Press.

Wierda, Howard J. (2010) Thinktanks and Foreign Policy. Lanham, Maryland: Lexington Books 